I N T ER N ATIONAL MONETARY FUND

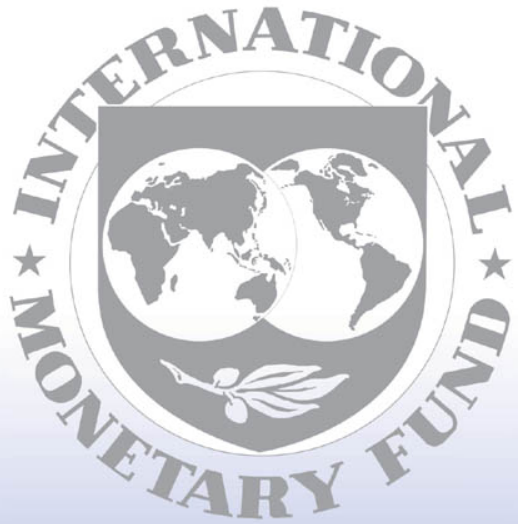

Staff

Country

Reports 


\title{
Republic of Armenia: Third Review Under the Stand-By Arrangement, Request for Waiver of Nonobservance of Performance Criterion, and Modification of Performance Criteria-Staff Report; Press Release on the Executive Board Discussion; and Statement by the Alternate Executive Director and Advisor for the Republic of Armenia.
}

In the context of the third review under the Stand-By Arrangement, request for waiver of nonobservance of performance criterion, and modification of performance criteria for the Republic of Armenia, the following documents have been released and are included in this package:

- $\quad$ The staff report for the Third Review Under the Stand-By Arrangement, Request for Waiver of Nonobservance of Performance Criterion, and Modification of Performance Criteria, prepared by a staff team of the IMF, following discussions that ended on February 17, 2010, with the officials of the Republic of Armenia on economic developments and policies. Based on information available at the time of these discussions, the staff report was completed on March 11, 2010. The views expressed in the staff report are those of the staff team and do not necessarily reflect the views of the Executive Board of the IMF.

- $\quad$ A Press Release summarizing the views of the Executive Board as expressed during its March 29, 2010, discussion of the staff report.

- A statement by the Alternate Executive Director and Advisor for the Republic of Armenia.

The documents listed below have been or will be separately released.

Letter of Intent sent to the IMF by the authorities of the Republic of Armenia* Technical Memorandum of Understanding*

*Also included in Staff Report

The policy of publication of staff reports and other documents allows for the deletion of market-sensitive information.

\author{
Copies of this report are available to the public from \\ International Monetary Fund • Publication Services \\ $70019^{\text {th }}$ Street, N.W. • Washington, D.C. 20431 \\ Telephone: (202) 623-7430 • Telefax: (202) 623-7201 \\ E-mail: publications@imf.org Internet: http://www.imf.org
}

\section{International Monetary Fund Washington, D.C.}




\title{
INTERNATIONAL MONETARY FUND
}

\author{
REPUBLIC OF ARMENIA
}

\author{
Third Review under the Stand-By Arrangement, \\ Request for Waiver of Nonobservance of Performance Criterion, and \\ Modification of Performance Criteria \\ Prepared by the Middle East and Central Asia Department \\ (In Consultation with Other Departments) \\ Approved by Ratna Sahay (MCD) and Thomas Dorsey (SPR)
}

March 11, 2010

- Stand-By A rrangement. A 28-month Stand-By Arrangement (SBA) in the amount of SDR 368 million ( 400 percent of quota) was approved by the Executive Board on March 6, 2009 (Country Report No. 09/140) and was subsequently augmented at the time of the completion of the first review on June 22, 2009 (Country Report No. 09/214). The augmentation increased total access under the SBA to SDR 534 million (580 percent of quota). On October 30, 2009, the Executive Board approved the second review of the SBA (Country Report No. 09/316). The authorities are requesting SDR 48.5 million to become available upon completion of this review.

- Program performance. All but one performance criterion for end-December were met and structural benchmarks were implemented largely as planned.

- Discussions. Discussions were held in Yerevan during February 4-17, 2010. The mission met with Prime Minister Sargsyan, Minister of Economy Yeritsyan, Minister of Finance Davtyan, Central Bank Chairman Javadyan, other senior officials, and representatives of financial institutions, the corporate sector, parliament, and the donor community. The staff team comprised V. Bacalu, A. Bordon, M. Lewis (head), A. Weber (all MCD), A. El-Ganainy (FAD), E. Gemayel (SPR), and D. Saeju (MCM). G. Tolosa (Resident Representative), and A. Manookian and A. Stepanyan (economists from the Resident Representative office) assisted the mission. G. Sargsyan (OED) joined the discussions.

- Publication. The authorities have consented to the publication of the staff report and the Letter of Intent. 


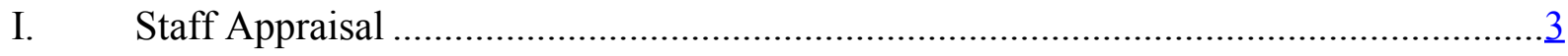

II. Economic Context.................................................................................................. 5

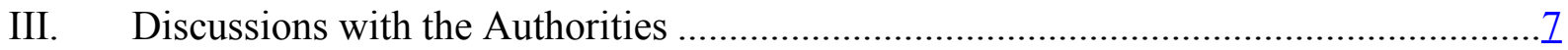

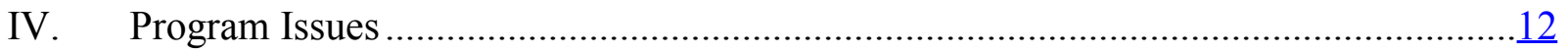

\section{Tables}

1. Selected Economic and Financial Indicators, 2006-10 ..........................................13

2. Balance of Payments, 2007-15 ............................................................................ 14

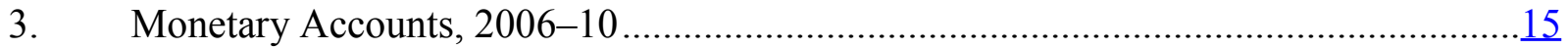

4. Financial Soundness Indicators for the Banking Sector, 2004-09 ...........................16

5. Central Government Operations, 2008-10 ...........................................................17

6. Central Government Operations, 2008-10 ........................................................18

7. Public Sector Debt Sustainability Framework, 2005-15 .......................................19

8. External Debt Sustainability Framework, 2005-15 .................................................20

9. Medium-Term Macroeconomic Framework, 2007-15..........................................21

10. Fund Disbursements and Timing of Reviews Under the Twenty-Eight Month Stand-By Arrangement, 2009-11................................................................22

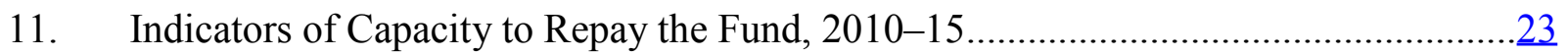

12. Macro-Criticality of Structural Benchmarks .......................................................24

Appendix

Analytical Background ..............................................................................................25

A. Price Developments in 2009 and Projections for Inflation in $2010-11 \ldots \ldots \ldots \ldots \ldots \ldots . . .25$

B. Estimating the Output Gap and the Cyclically-Adjusted Fiscal Balance..................27

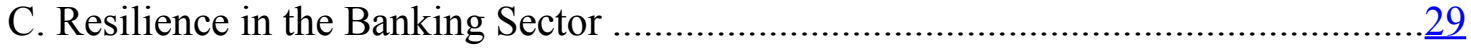

D. External Debt Analysis ................................................................................. 31

Attachments

I. Letter of Intent ...............................................................................................

II. Technical Memorandum of Understanding ...................................................... 41 
I.

StAfF APpraisal

1. The deep recession appears to have bottomed out, yet important challenges remain. The dramatic fall in output and inflows appears to be over, but output growth will likely remain low in the face of a weak external environment and the unlikely return of the earlier remittance-fueled construction boom. Thus, the main challenge will be to support the fragile economic recovery while gradually adjusting policies in light of the external outlook.

2. Performance under the program has been good. Program targets were largely met, with the target on net domestic assets of the Central Bank of Armenia (CBA) missed by only a small margin, and structural reforms continued. The authorities have adjusted policies in a manner consistent with macroeconomic stability, and are clearly aware of the challenges ahead.

3. Looking forward, greater exchange rate flexibility will be essential to a sound policy mix. While the authorities remain committed to the flexible exchange rate regime, they have, at times, influenced the exchange rate to mitigate potential inflation pressures. While intervention to avoid sharp exchange rate movements and allow some absorption of the sizable foreign assistance inflows is warranted, this should not come at the expense of long-term macroeconomic stability and underlying trends. Staff supports the CBA's plans to strengthen foreign exchange-related prudential regulations, including measures to enhance foreign exchange risk management.

4. The shift from an accommodative to a more neutral monetary policy, supported by a more transparent monetary framework and effective communication strategy, is warranted. The recent uptick in inflation was largely driven by exogenous factors, but it is important that these do not feed into further inflationary expectations. Thus, adjusting the policy rate so that it becomes positive in real terms is appropriate. In addition, the planned steps to strengthen the transmission mechanism are needed and welcome, complemented by measures to discourage dollarization. Nonetheless, and mindful of the need for increased exchange rate flexibility, the outlook for inflation will remain challenging, raising valid questions about the appropriate monetary framework. In this regard, staff supports CBA's efforts to strengthen its inflation targeting framework, underpinned by a sound communication strategy. At the same time, the authorities should avoid relying on the exchange rate to stabilize inflation expectations and also avoid frequently changing the monetary regime, which could undermine the credibility of the central bank.

5. Continued close supervision of the financial sector will be critical. The financial sector has been resilient to the crisis and almost all banks are well capitalized. Nonetheless, risks remain, notably on the credit side. The authorities' efforts to tighten foreign exchange-related prudential regulations and to improve crisis preparedness and contingency planning are welcome. 
6. On fiscal policy, supportive policies are warranted in the short term, but deficits should be brought down over the medium term. The fiscal stimulus has appropriately supported the economy during the crisis and maintaining priority public spending has been critical for mitigating the impact of the crisis on the poor. As the recovery gains strength, fiscal consolidation will be needed, with the aim of bringing the budget deficit below 3 percent of GDP in 3-4 years. In addition, staff encouraged the authorities to adopt an appropriate social indicator to help monitor the effectiveness of social policies in reducing poverty.

7. Renewed reforms will be essential to strengthening the medium-term fiscal position and the provision of public goods. Efforts to strengthen tax administration and advance tax policy reforms have had mixed success. Progress in these areas will be critical to sustained improvements to Armenia's currently low tax-to-GDP ratio, and it is important that the authorities avoid further delays. Likewise, restoring the medium-term expenditure framework (MTEF) will be needed in situating public spending consistent with fiscal sustainability over the medium term.

8. Staff supports the authorities' request for completion of the third review. Staff also supports a waiver of nonobservance of performance criterion, modification of performance criteria for end-March 2010, and setting of performance criteria for end-June 2010. Risks to the program are broadly balanced. Reflecting in large part uncertainties over the external outlook, there are upside and downside risks to economic growth. The mediumterm balance of payments remains an important concern, although policies under the program are aimed at addressing these weaknesses. Armenia's capacity to repay the Fund broadly remains good. 
II.

9. The crisis appears to be over as the economy is showing signs of recovery.

- $\quad$ After a deep downturn, output is stabilizing. Real GDP contracted by 14.4 percent in 2009 , but started recovering by the fourth quarter. The construction and real estate sectors are improving, but continue to drag down GDP growth. Rising metal prices have spurred greater activity in the mining sector, and services and retail trade continue to be resilient.

- External inflows have started to recover, but remain weak. Despite signs of improvement during the second half of the year, the external position deteriorated in 2009. The current account deficit widened to 13.8 percent of GDP as exports and remittances contracted by one-third while imports dropped by a quarter. However, with sizable financial inflows, particularly government borrowing, official reserves remained at a comfortable level.

- $\quad$ Public finances are recovering gradually as revenue picked up in recent months. After a dramatic drop earlier in 2009, 12-month tax revenue growth edged up in the fourth quarter. Expenditures, including higher capital spending, were in line with program targets. As expected, the deficit widened to $7 \frac{1}{2}$ percent of GDP, up from about $1 \frac{1}{2}$ percent in 2008 .
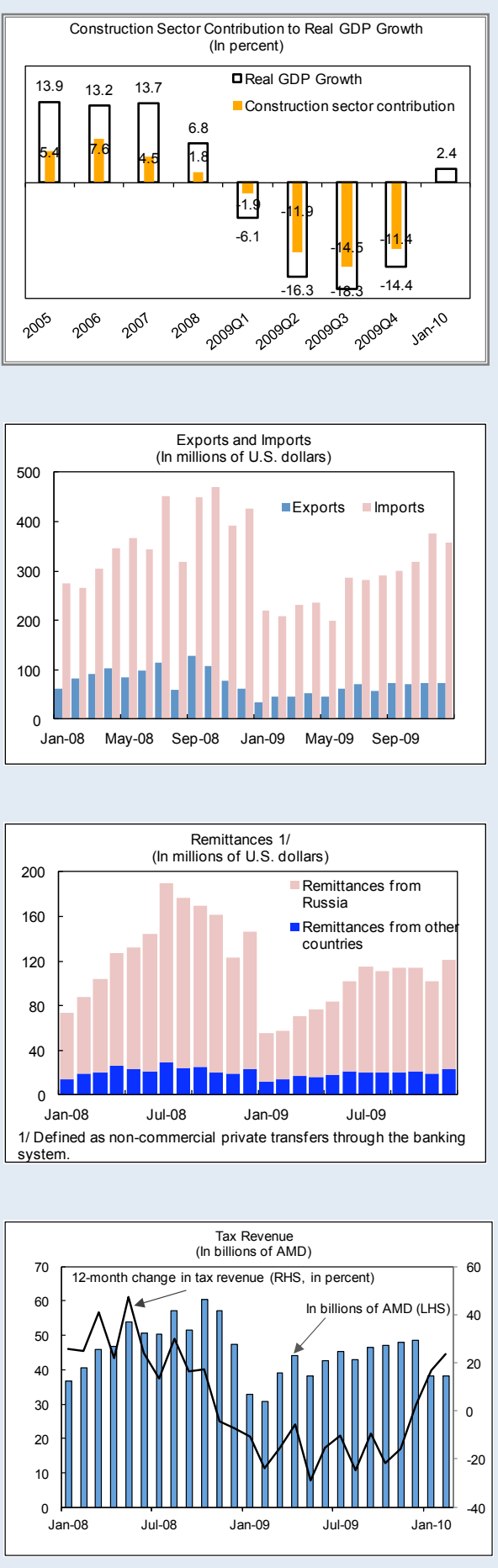

Sources: Armenian authorities; and Fund staff estimates. 
10. Recently, inflation pressures have emerged as a concern.

- $\quad$ CPI inflation edged up by end-2009. It reached $6 \frac{1}{2}$ percent in December, exceeding the CBA target of $4 \pm 1 \frac{1}{2}$ percent and continued to rise through end-February 2010, reaching 9 percent. It has been largely driven by increases in world commodity prices, pass-through effects from the March 2009 depreciation, and increases in administrative prices (see Appendix, Section A).

11. Financial conditions have been broadly stable, but dollarization remains high.
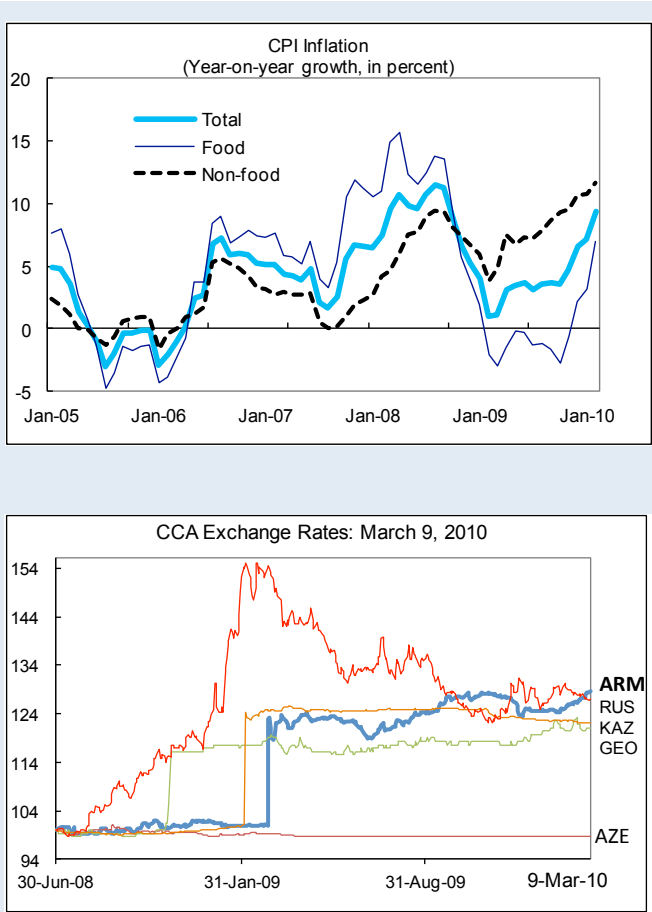

- $\quad$ The dram has been trading in a relatively narrow range against the dollar. Exchange rate pressures emerged in the fourth quarter, mainly reflecting seasonal factors and outflows due to public spending. In real effective terms, the dram is 19 percent below its February 2009 peak, although updated estimates of the equilibrium real exchange rate suggest that a small overvaluation remains.

\section{- $\quad$ The credit crunch had eased by end-} 2009. Increasing economic activity and improving loan portfolios, along with continued government-led refinancing programs, helped spur banks to increase lending in the last quarter of 2009. However, dram lending continues to be subdued; with the high dollarization of bank deposits, banks try to minimize their risks and balance their foreign currency positions.
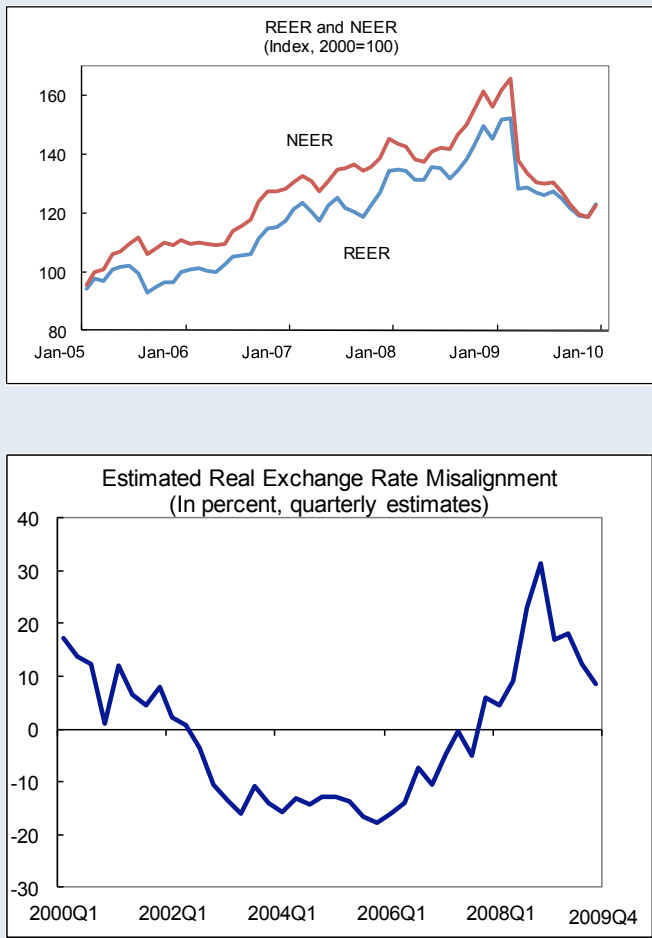

Sources: Armenian authorities; and Fund staff estimates. 
12. Program performance was on track.

- $\quad$ Almost all quantitative and structural targets for end-December were met. Targets for the fiscal deficit (including for end-September, which had been granted a waiver at the time of the last review), net banking system credit to the government, and net international reserves were met. The target on net domestic assets of the CBA was narrowly and temporarily missed for end-December given the high liquidity demand ahead of a new 10-day holiday at the beginning of January 2010. Also, the indicative target on the stock of tax credits for end-December was missed. Structural benchmarks were implemented largely as planned (LOI $\mid 2$ and Table 2).

\section{Discussions With the Authorities}

13. With a better global and regional outlook, prospects for recovery have improved, but important weaknesses remain for 2010 and the medium term.

- $\quad$ Real GDP is expected to grow by about 2 percent in 2010, with risks to the outlook broadly balanced. Potential output in Armenia has been affected through adverse effects on capital inflows, remittances, and exports. The resulting plunge in private investment has reduced potential GDP through a fall in the capital stock, which will take time to rebuild. Thus, despite higher external demand, notably from Russia, the pace of Armenian recovery is

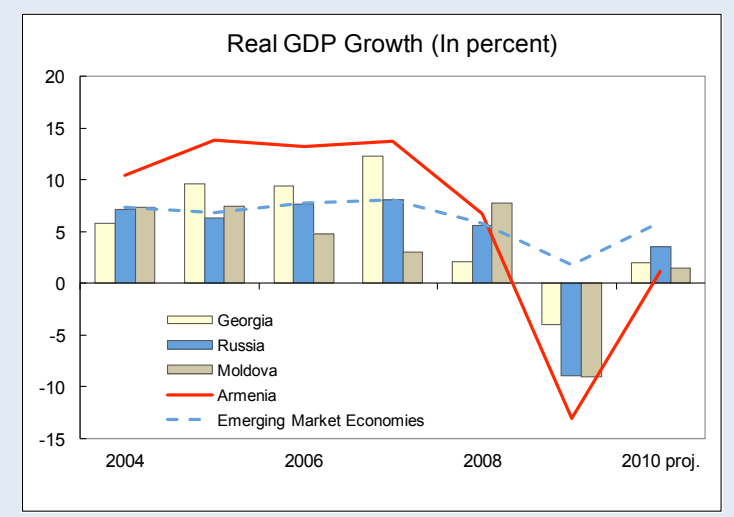

Sources: Armenian authorities; and Fund staff estimates. uncertain. With the construction sector providing a negative contribution to GDP growth in 2010, industry and services are likely to be the main drivers of the recovery. Risks to medium-term growth remain two-sided, reflecting the outlook for the regional and global recovery. The possible reopening of the Turkish-Armenian land border represents an important upside risk. 
- Inflation is expected to stay outside the $C B A$ 's target range in 2010, but is projected to revert in 2011. Given lags in the exogenous factors, inflation is expected to remain elevated through mid-2010.

However, with output below potential and prudent macroeconomic policies, there is less chance of sustained inflation, which is projected to return to the target zone from mid-2011 onwards.

- $\quad$ External imbalances are expected to persist in 2010, gradually receding over the medium term. The current account deficit is projected to narrow slightly to 13 percent of GDP against the backdrop of a still fragile recovery in external demand and remittances, offsetting rising imports bolstered by externally-financed public spending in 2009-10. Over the medium term, the current account is projected to gradually narrow, but will require substantial gains in competitiveness through additional commitments to exchange rate flexibility and acceleration in structural reforms.

\section{- $\quad$ Rising public debt and a bulging debt} service profile have emerged as concerns.

With the authorities' crisis response having been financed in good part by public borrowing, external public debt has increased sharply, and is projected to peak at 45 percent of GDP in 2011 before gradually declining. Debt service, due in part to repayments to the Fund, is also expected to be high in 2012-14 before falling thereafter. While restored growth and current account adjustment should ensure public debt sustainability over the medium term, the debt outlook remains sensitive to a real exchange rate shock (LOI $\mid 18$ ). Thus, sound debt management will be crucial (see Appendix, Section D).
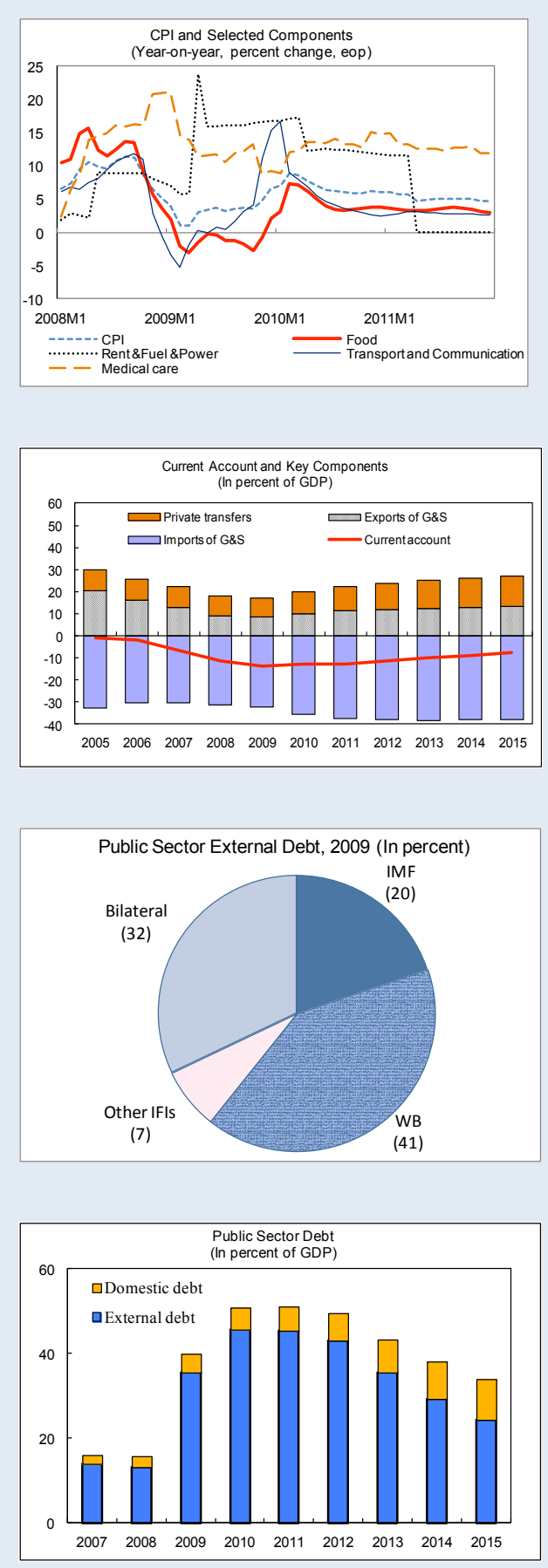

Sources: Armenian authorities; and Fund staff estimates. 
14. Further exchange rate flexibility will be critical to addressing the policy challenges...

- $\quad$ While the authorities remain committed to the flexible exchange rate regime, recent interventions may be more than is needed to smooth volatility. The CBA is concerned that with inflation picking up, more rapid depreciation might lead to a high and persistent inflation. Staff stressed that intervening to avoid sharp exchange rate movements and allowing some absorption of sizable foreign assistance inflows was warranted, but it is important not to resist the underlying trends. Moreover, excessive focus on short-term stability of the exchange rate could come at the expense of long-term macroeconomic stability.

\section{5. ...supported by sound monetary}

\section{policies...}

- $\quad$ The CBA is gradually shifting to a more neutral stance. The CBA believes that some excess demand from last year's expansionary policies has contributed to inflationary pressures. The CBA has already increased its policy rate in three steps by 150 basis points since January and intends to continue increases until it becomes positive in real terms based on inflation expectations. In addition, it has tightened liquidity, including by reducing the stock of repos, which caused the market rates to rise above the policy rate.

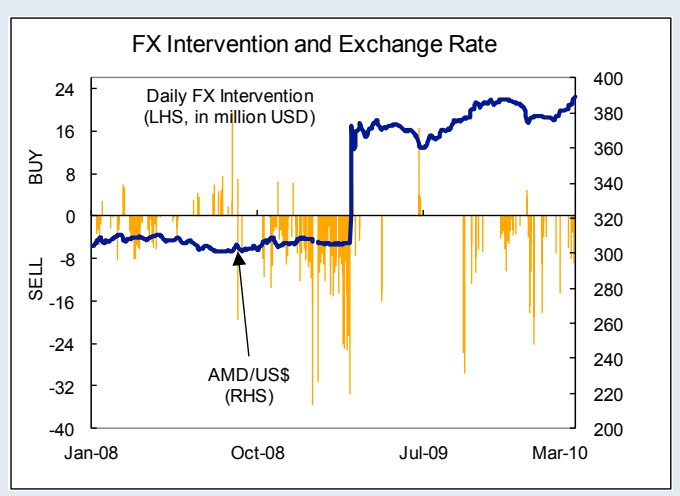

Sources: Armenian authorities; and Fund staff estimates.

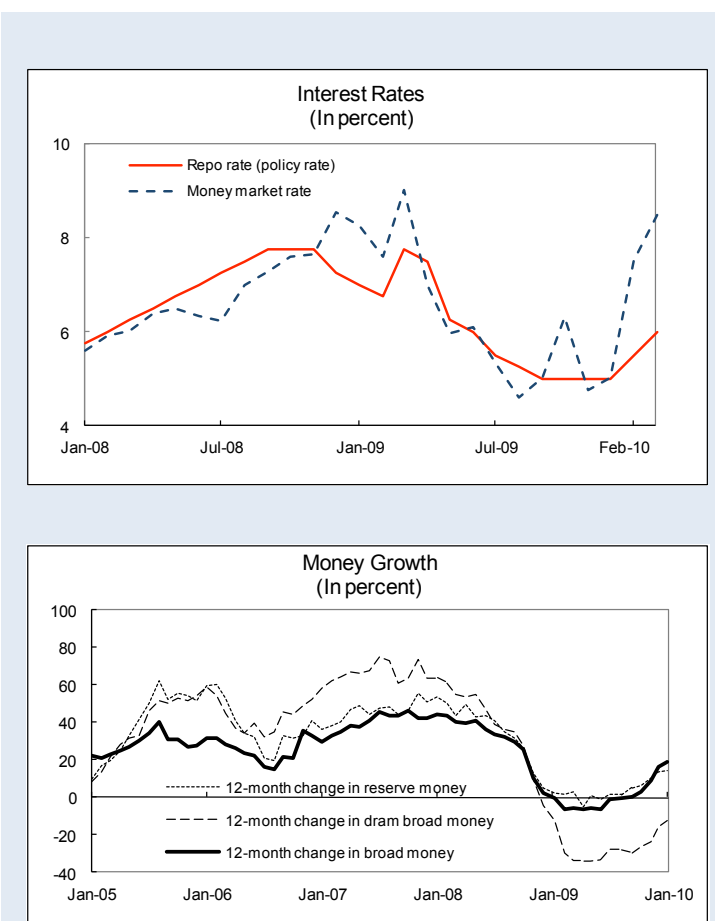

Sources: Armenian authorities; and Fund staff estimates. 
- $\quad$ The CBA is taking steps to strengthen its inflation targeting framework. It is initiating dedollarization measures, introducing trading mechanisms to deepen the secondary market, and using available instruments to manage liquidity (LOI 98 ). However, the public's persistently high preference for foreign currency has reduced the effectiveness of monetary policy. As a result, some consideration has been given to reverting to targeting monetary aggregates. Staff underlined that there were important limitations to any regime in the current setting, but that frequently changing monetary regimes undermines policy credibility. Moreover, targeting the monetary base has proved ineffective in the past, cannot overcome the underlying weaknesses of the transmission mechanism, and risks over-determining monetary and exchange rate policies.

16. ....and measures to limit vulnerabilities in the banking system to safeguard financial stability.

- $\quad$ The authorities are taking further steps to enhance banking supervision and regulations (LOI $\$ 11)$. The system remains highly capitalized with improved asset quality and profitability (see Appendix, Section C). However, significant risks remain from foreign currency exposure to unhedged borrowers. The CBA is thus planning to tighten foreign exchange-related prudential regulations regarding loanloss provisioning and capital requirements (structural benchmark, June 2010) to enhance banks' risk management as well as encourage dedollarization.

- $\quad$ The CBA continues to improve its crisis preparedness and contingency planning. This year, the CBA plans to formalize the Committee for Financial Stability and require banks to prepare their contingency plans (structural benchmarks for September and December 2010, respectively).

17. Fiscal policy will need to balance short and medium-term concerns, while maintaining adequate social spending.

- $\quad$ The overall fiscal stance is appropriate in 2010. Narrowing the fiscal deficit to about $5 \frac{1}{2}$ percent of GDP strikes a balance between the need to start bringing down the deficit — in light of debt sustainability and financing concerns — and avoiding an overly negative impulse to economic activity. The deficit target implies a slightly contractionary stance, given the output gap cycle (see Appendix, Section B). The authorities intend to implement contingency measures should revenue diverge from 
projections (LOI $\llbracket 13$ ). In particular, in the event of revenue shortfalls, non-priority expenditure would be cut or postponed. On the other hand, any revenue overperformance would largely be saved.

- $\quad$ The authorities agreed that the deficit should gradually decline below 3 percent of GDP over the medium term. This would imply an annual adjustment of about 1 percent of GDP in 2011-13, which would come mainly from higher revenue due to enhanced tax administration and limiting spending increases in nominal terms.

\section{- $\quad$ Social spending will be protected in} 2010. With poverty picking up in the wake of the crisis, average pensions and family benefits have increased over the past two years, while targeting of the latter has improved. Going forward, to protect the poor, the authorities aim to maintain social spending in 2010 broadly at the nominal level of 2009. This would allow savings from enhanced targeting of the family benefit

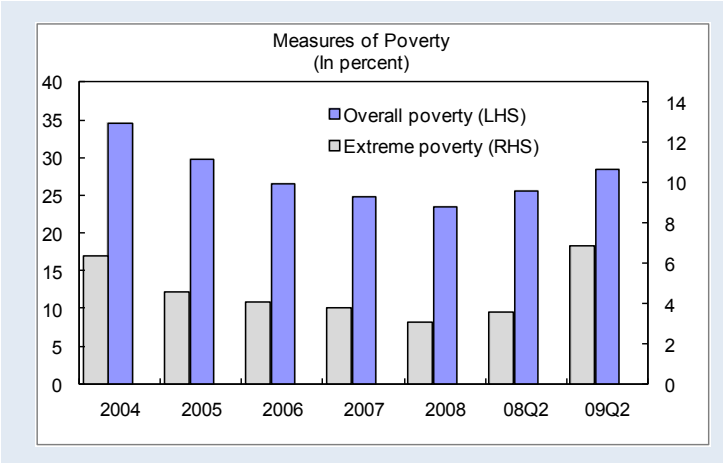

Sources: Armenian authorities; and Fund staff estimates. program to be extended to other eligible families. Moreover, the authorities plan to establish a social indicator that would help assess the effectiveness of their social policies in reducing poverty (LOI $\mid 20$ ).

18. The authorities should step up their structural reforms to bolster macroeconomic stability and boost growth.

- $\quad$ Progress in tax reforms has been mixed. On tax administration, while delays in VAT refunds have been shortened, the introduction of risk-based auditing and e-filing is progressing slowly, and the challenge of reducing tax credits persists. Continued efforts are being directed at boosting collections from large taxpayers. Regarding tax policy, the authorities plan to abolish the current presumptive taxation regimes for all products, notably for tobacco and fuel, by January 2011 (LOI $\$ 17$ ), and will introduce a number of other tax policy changes in a revised tax code, which is expected to be submitted to parliament by end- 2010 .

- $\quad$ The fast erosion of fiscal space calls for an early adoption of a debt management strategy. Although Armenia's debt is expected to remain sustainable over the medium term, future official borrowing needs to be selective in terms of ensuring adequate concessionality and efficiency and a manageable schedule of debt service payments. To this end, a strengthened MTEF for 2011-13 will be reintroduced this year (structural benchmark, July 2010, LOI $\uparrow 14$ and Table 2) and an action plan for implementing a debt management strategy will be adopted by June (LOI $₫ 18$ ). 
- $\quad$ The authorities are committed to other broad-based structural reforms to enhance productive capacity and promote long-term growth. These include maintaining an open trade regime, improving the business environment, focusing on the ease of doing business and anti-corruption efforts, and increasing competition to eliminate market domination in key sectors (LOI $₫ 19$ ).

\section{PROGRAM ISSUES}

19. Risks to the program have lessened somewhat, but still subsist. Policymakers face several challenges, in particular the need to support the fragile economic recovery, address external vulnerabilities - including rising external debt and debt service obligations - as well as the need to advance with a credible fiscal consolidation plan over the medium term.

\section{The attached $L O I$ describes the authorities' progress in implementing their} economic program, and sets out conditionality through end-2010:

- The authorities request a waiver of nonobservance for the end-December performance criterion on net domestic assets of the central bank, which was narrowly missed due to strong temporary liquidity demands in the last few days of the year in advance of the unusually long holiday period.

- The LOI sets quantitative performance criteria for end-June 2010 and new structural benchmarks for the year. Also, given the changing economic outlook, the authorities are requesting the modification of the end-March performance criteria. In addition, the authorities would like to reintroduce the indicative target on reserve money.

21. Armenia's capacity to repay the Fund broadly remains good and is in line with the assessment made at the time of the last review. The CBA and the ministry of finance have signed a Memorandum of Understanding to safeguard Fund resources directed for budget support.

22. The authorities have signaled their interest in possibly moving to a new program at the time of the next review (LOI $\mid 22$ ). Staff agrees that as the crisis recedes and important medium-term challenges emerge, shifting to a Fund facility more tailored to such challenges could be warranted. On this basis, and in light of the new blend criteria, the new arrangement would likely be an EFF/ECF blend. Several changes to program design would be considered, including revising the targets on debt limits in line with the recently adopted debt limit framework. 
Table 1. Armenia: Selected Economic and Financial Indicators, 2006-10

\begin{tabular}{|c|c|c|c|c|c|c|}
\hline & $\begin{array}{l}2006 \\
\text { Act. }\end{array}$ & $\begin{array}{l}2007 \\
\text { Act. }\end{array}$ & $\begin{array}{l}2008 \\
\text { Act. }\end{array}$ & $\begin{array}{c}\frac{2009}{\text { Country Report }} \\
\text { No. } 09 / 316\end{array}$ & $\frac{2009}{\text { Prel. }}$ & $\begin{array}{l}2010 \\
\text { Proj. }\end{array}$ \\
\hline \multicolumn{7}{|l|}{ National income and prices } \\
\hline Real GDP (percent change) & 13.2 & 13.7 & 6.8 & -15.6 & -14.4 & 1.8 \\
\hline Gross domestic product (in billions of drams) & 2,656 & 3,149 & 3,646 & 3,116 & 3,166 & 3,337 \\
\hline Gross domestic product (in millions of U.S. dollars) & 6,384 & 9,206 & 11,917 & 8,683 & 8,714 & 8,271 \\
\hline Gross domestic product per capita (in U.S. dollars) & 1,982 & 2,853 & 3,685 & 2,658 & 2,668 & 2,507 \\
\hline $\mathrm{CPI}$ (period average; percent change) & 2.9 & 4.4 & 9.0 & 3.2 & 3.4 & 6.8 \\
\hline CPI (end of period; percent change) & 5.2 & 6.6 & 5.2 & 5.2 & 6.5 & 6.2 \\
\hline GDP deflator (percent change) & 4.6 & 4.2 & 8.4 & 1.3 & 1.5 & 3.6 \\
\hline Unemployment rate (in percent) & 7.5 & 7.0 & 6.3 & $\ldots$ & 6.9 & $\ldots$ \\
\hline Poverty rate (in percent) $1 /$ & 26.5 & 25.0 & 23.5 & $\ldots$ & 28.0 & $\ldots$ \\
\hline \multicolumn{7}{|l|}{ Investment and saving (in percent of GDP) } \\
\hline Investment & 33.6 & 38.2 & 42.8 & 36.0 & 36.5 & 36.5 \\
\hline National savings & 31.7 & 31.8 & 31.2 & 22.2 & 22.7 & 23.5 \\
\hline \multicolumn{7}{|l|}{ Money and credit (end of period) } \\
\hline Reserve money (percent change) & 41.1 & 50.9 & 5.3 & 11.2 & 13.8 & 10.0 \\
\hline Broad money (percent change) & 32.9 & 42.3 & 2.4 & 13.0 & 16.4 & 12.0 \\
\hline Commercial banks' 3-month lending rate (in percent) & 17.1 & 18.6 & 17.9 & $\ldots$ & 19.1 & $\ldots$ \\
\hline \multicolumn{7}{|l|}{ Central government operations (in percent of GDP) } \\
\hline Revenue and grants & 18.0 & 20.1 & 20.0 & 20.5 & 20.7 & 22.1 \\
\hline Of which: tax revenue & 14.5 & 16.0 & 16.4 & 15.9 & 16.0 & 16.4 \\
\hline Expenditure 2/ & 20.0 & 22.4 & 21.8 & 28.0 & 28.2 & 27.7 \\
\hline Overall balance on a cash basis & -2.2 & -2.2 & -1.1 & -7.5 & -7.8 & -5.6 \\
\hline Overall balance (excl. projects related to the Russian loan) & $\ldots$ & $\ldots$ & $\ldots$ & -6.7 & -6.7 & -4.9 \\
\hline Government and government-guaranteed debt & 18.7 & 16.1 & 15.9 & 37.4 & 39.8 & 50.8 \\
\hline Share of foreign currency debt (in percent) & 88.1 & 86.7 & 83.7 & 89.2 & 88.9 & 90.0 \\
\hline \multicolumn{7}{|l|}{ External sector } \\
\hline Exports of goods and services (in millions of U.S. dollars) & 1,510 & 1,777 & 1,711 & 1,272 & 1,328 & 1,509 \\
\hline Imports of goods and services (in millions of U.S. dollars) & $-2,536$ & $-3,589$ & $-4,692$ & $-3,588$ & $-3,663$ & $-3,806$ \\
\hline Exports of goods and services (percent change) & 6.7 & 17.6 & -3.7 & -25.6 & -22.4 & 13.6 \\
\hline Imports of goods and services (percent change) & 19.4 & 41.5 & 30.7 & -23.5 & -21.9 & 3.9 \\
\hline Current account balance (in percent of GDP) & -1.8 & -6.4 & -11.5 & -13.7 & -13.8 & -13.0 \\
\hline FDI (net, in millions of U.S. dollars) & 450 & 701 & 929 & 263 & 478 & 525 \\
\hline External debt (in percent of GDP) 3/ & 18.9 & 15.7 & 13.2 & 31.1 & 34.0 & 43.0 \\
\hline Debt service ratio (in percent of exports of goods and services) & 3.9 & 2.9 & 3.2 & 6.5 & 5.4 & 6.3 \\
\hline Gross international reserves (in millions of U.S. dollars) 4/ & 1,072 & 1,659 & 1,407 & 1,910 & 2,003 & 2,172 \\
\hline Import cover 5/ & 3.6 & 4.2 & 4.6 & 6.1 & 6.3 & 6.5 \\
\hline Nominal effective exchange rate (percent change) $6 /$ & 10.1 & 15.0 & 9.0 & $\ldots$ & -8.9 & $\ldots$ \\
\hline Real effective exchange rate (percent change) 6/ & 9.1 & 15.3 & 11.7 & $\ldots$ & -6.0 & $\ldots$ \\
\hline End-of-period exchange rate (dram per dollar) & 364 & 304 & 307 & $\ldots$ & 378 & $\ldots$ \\
\hline Average exchange rate (dram per dollar) & 416 & 342 & 306 & $\ldots$ & 363 & $\ldots$ \\
\hline \multicolumn{7}{|l|}{ Memorandum item: } \\
\hline Population (in millions) & 3.2 & 3.2 & 3.2 & $\ldots$ & $\ldots$ & $\ldots$ \\
\hline
\end{tabular}

Sources: Armenian authorities; and Fund staff estimates and projections.

1/ For 2009, Q3 preliminary estimates.

2/ Including the gas subsidy in 2006-08.

$3 /$ Based on government and government-guaranteed debt.

4/ Excluding the special privatization account (SPA), but including the Russian project loan.

$5 /$ Gross international reserves in months of next year's imports of goods and services, including the SDR allocation.

6/ A positive sign denotes appreciation.

\section{CInternational Monetary Fund. Not for Redistribution}


Table 2. Armenia: Balance of Payments, 2007-15

(In millions of U.S. dollars, unless otherwise indicated)

\begin{tabular}{|c|c|c|c|c|c|c|c|c|c|}
\hline & 2007 & 2008 & 2009 & 2010 & 2011 & 2012 & 2013 & 2014 & 2015 \\
\hline & Act. & Act. & Prel. & \multicolumn{6}{|c|}{ Projections } \\
\hline Current account & -589 & $-1,372$ & $-1,205$ & $-1,072$ & $-1,047$ & -994 & -913 & -847 & -800 \\
\hline Trade balance & $-1,600$ & $-2,654$ & $-2,080$ & $-2,102$ & $-2,148$ & $-2,239$ & $-2,332$ & $-2,427$ & $-2,559$ \\
\hline Exports, fob & 1,197 & 1,066 & 729 & 838 & 939 & 1,033 & 1,136 & 1,250 & 1,375 \\
\hline Imports, fob & $-2,797$ & $-3,720$ & $-2,809$ & $-2,940$ & $-3,087$ & $-3,272$ & $-3,469$ & $-3,677$ & $-3,934$ \\
\hline Services (net) & -213 & -327 & -237 & -195 & -167 & -155 & -139 & -130 & -118 \\
\hline Credits & 580 & 645 & 599 & 670 & 751 & 818 & 892 & 963 & 1,040 \\
\hline Debits & -793 & -972 & -836 & -866 & -918 & -973 & $-1,031$ & $-1,093$ & $-1,159$ \\
\hline Income (net) & 279 & 471 & 304 & 338 & 355 & 371 & 386 & 399 & 412 \\
\hline Transfers (net) & 945 & 1,138 & 808 & 888 & 913 & 1,028 & 1,172 & 1,311 & 1,465 \\
\hline Private & 850 & 1,062 & 742 & 800 & 895 & 1,003 & 1,123 & 1,258 & 1,409 \\
\hline Official & 94 & 75 & 66 & 88 & 17 & 25 & 49 & 53 & 56 \\
\hline Capital and financial account & 1,191 & 1,124 & 1,318 & 970 & 915 & 971 & 947 & 1,029 & 1,014 \\
\hline Capital transfers (net) & 143 & 149 & 98 & 116 & 127 & 140 & 154 & 169 & 182 \\
\hline Foreign direct investment (net) & 701 & 929 & 478 & 525 & 568 & 613 & 662 & 715 & 758 \\
\hline Portfolio investment (net) & -9 & 8 & 0 & 0 & 0 & 0 & 0 & 0 & 0 \\
\hline Public sector (net) & 133 & 145 & 1,023 & 449 & 309 & 288 & 192 & 198 & 116 \\
\hline Disbursements & 149 & 160 & 907 & 474 & 337 & 319 & 270 & 280 & 215 \\
\hline Amortization & -17 & -15 & -21 & -25 & -28 & -31 & -78 & -82 & -99 \\
\hline CBA & 0 & 0 & 137 & 0 & 0 & 0 & 0 & 0 & 0 \\
\hline Other capital (net) & 224 & -107 & -280 & -120 & -89 & -70 & -61 & -54 & -41 \\
\hline Errors and omissions & -2 & 15 & 16 & 0 & 0 & 0 & 0 & 0 & 0 \\
\hline Overall balance & 600 & -233 & 129 & -102 & -132 & -23 & 34 & 182 & 215 \\
\hline Financing & -600 & 233 & -129 & -189 & 66 & 23 & -34 & -182 & -215 \\
\hline Gross international reserves ("-" means increase) 1/ & -587 & 252 & -597 & -169 & 87 & 182 & 222 & -68 & -210 \\
\hline Use of Fund credit, net & -14 & -20 & 466 & -23 & -23 & -161 & -258 & -115 & -7 \\
\hline Purchases/disbursements & 10 & 7 & 468 & $\ldots$ & $\ldots$ & $\ldots$ & $\ldots$ & $\ldots$ & $\ldots$ \\
\hline Repurchases/repayments & -24 & -27 & -2 & -23 & -23 & -161 & -258 & -115 & -7 \\
\hline Exceptional financing $2 /$ & 1 & 0 & 2 & 2 & 2 & 2 & 2 & 2 & 2 \\
\hline $\begin{array}{l}\text { Financing gap } \\
\text { Identified financing }\end{array}$ & 0 & 0 & 0 & 291 & 66 & 0 & 0 & 0 & 0 \\
\hline IMF SBA & 0 & 0 & 0 & 291 & 56 & 0 & 0 & 0 & 0 \\
\hline Other & 0 & 0 & 0 & 0 & 10 & 0 & 0 & 0 & 0 \\
\hline \multicolumn{10}{|l|}{ Memorandum items: } \\
\hline Financing gap (Country Report No. 09/316) & 0 & 0 & 58 & 440 & 66 & 0 & 0 & 0 & 0 \\
\hline Current account (in percent of GDP) & -6.4 & -11.5 & -13.8 & -13.0 & -12.6 & -11.6 & -10.1 & -8.8 & -7.7 \\
\hline Trade balance (in percent of GDP) & -17.4 & -22.3 & -23.9 & -25.4 & -25.9 & -26.0 & -25.8 & -25.1 & -24.8 \\
\hline Gross international reserves (end of period) & 1,659 & 1,407 & 2,003 & 2,172 & 2,085 & 1,903 & 1,680 & 1,749 & 1,959 \\
\hline In months of next year's imports & 4.2 & 4.6 & 6.3 & 6.5 & 5.9 & 5.1 & 4.2 & 4.1 & 4.4 \\
\hline Net international reserves (program definition) & 1,350 & 1,057 & 1,019 & 889 & 853 & 779 & 688 & 716 & 801 \\
\hline Merchandise export growth, percent change & 16.7 & -10.9 & -31.6 & 15.0 & 12.0 & 10.0 & 10.0 & 10.0 & 10.0 \\
\hline Merchandise import growth, percent change & 45.6 & 33.0 & -24.5 & 4.7 & 5.0 & 6.0 & 6.0 & 6.0 & 7.0 \\
\hline Nominal external debt $3 /$ & 1,449 & 1,577 & 2,967 & 3,553 & 3,727 & 3,593 & 3,225 & 2,771 & 2,540 \\
\hline Nominal external debt stock (in percent of GDP) 3/ & 15.7 & 13.2 & 34.0 & 43.0 & 44.9 & 41.8 & 35.6 & 28.6 & 24.6 \\
\hline External debt-to-exports ratio (in percent) $3 /$ & 81.6 & 92.2 & 223.5 & 235.5 & 220.6 & 194.1 & 159.0 & 125.2 & 105.2 \\
\hline External debt service in percent of exports $3 /$ & 2.9 & 3.2 & 5.4 & 6.3 & 6.2 & 13.4 & 21.6 & 18.1 & 11.0 \\
\hline
\end{tabular}

Sources: Armenian authorities; and Fund staff estimates and projections.

1/ Gross international reserves include the SDR allocation.

2/ Debt relief from the United Kingdom through 2015 (in respect of IDA credits).

3 / Based on government and government-guaranteed debt. 
Table 3. Armenia: Monetary Accounts, 2006-10

(n billions of drams, unless otherwise indicated)

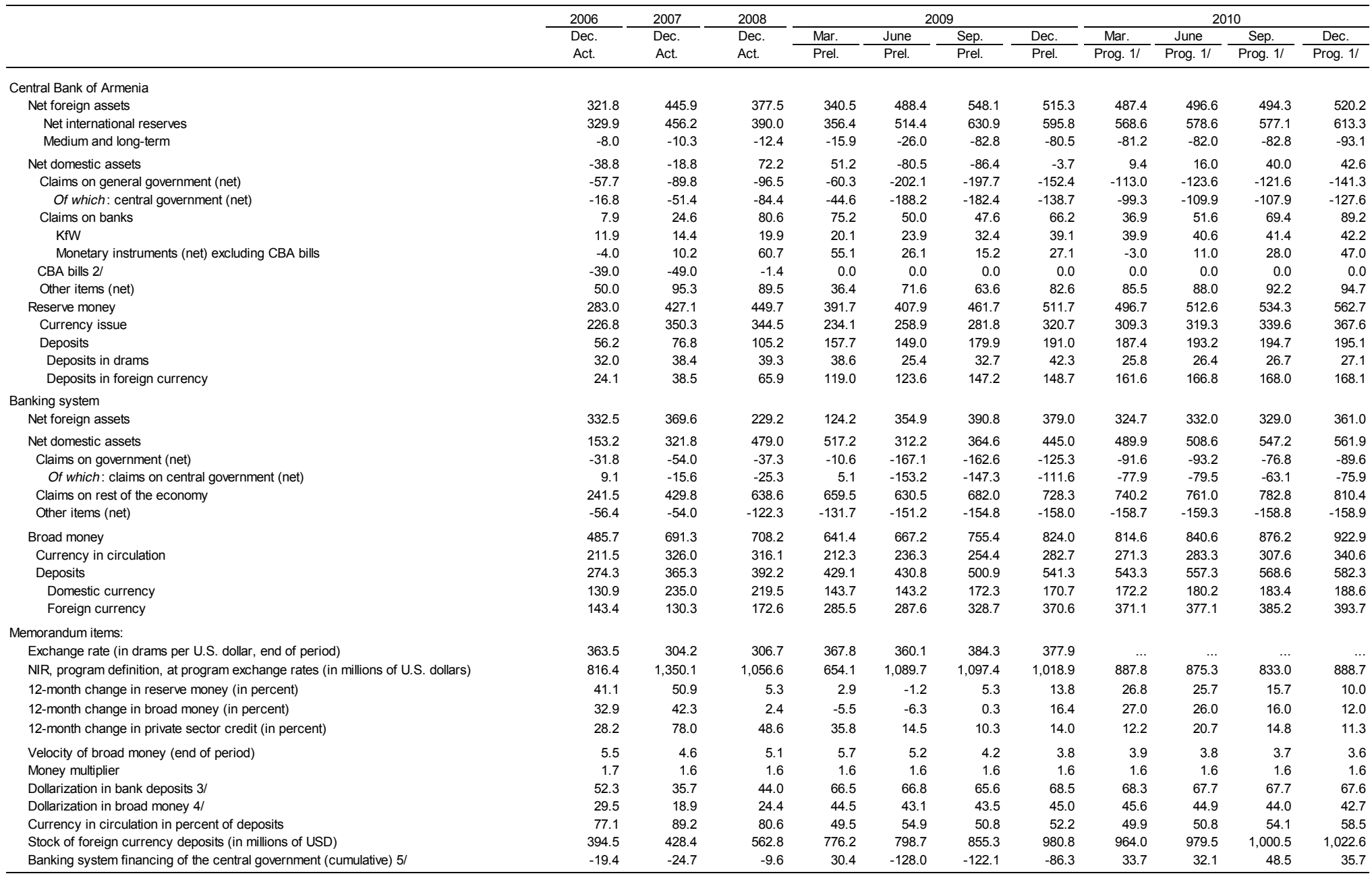

Sources: Central Bank of Armenia; and Fund staff estimates and projections.

1/ At the program exchange rate.

2/ Following the agreement between the CBA and the Ministry of Finance, the issue of new CBA bills was terminated in 2008.

3/ Ratio of foreign currency deposits to total deposits (in percent).

4/ Ratio of foreign currency deposits to broad money (in percent).

5/ Discrepancy between the fiscal and monetary accounts in 2009Q3-Q4, 2010Q1 is explained by government lending to the economy through commercial banks. 
Table 4. Armenia: Financial Soundness Indicators for the Banking Sector, 2004-09 (In percent, unless otherwise indicated)

\begin{tabular}{|c|c|c|c|c|c|c|c|c|c|c|c|c|}
\hline & \multirow{2}{*}{$\begin{array}{l}2004 \\
\text { Dec. }\end{array}$} & \multirow{2}{*}{$\begin{array}{l}2005 \\
\text { Dec. }\end{array}$} & \multirow{2}{*}{$\begin{array}{c}2006 \\
\text { Dec. }\end{array}$} & \multirow{2}{*}{$\begin{array}{l}2007 \\
\text { Dec. }\end{array}$} & \multicolumn{4}{|c|}{2008} & \multicolumn{4}{|c|}{2009} \\
\hline & & & & & Mar. & Jun. & Sep. & Dec. & Mar. & Jun. & Sep. & Dec. \\
\hline \multicolumn{13}{|l|}{ Capital adequacy } \\
\hline Total regulatory capital to risk-weighted assets & 32.3 & 33.7 & 34.9 & 30.1 & 27.0 & 26.0 & 27.2 & 27.5 & 26.1 & 28.0 & 28.3 & 28.3 \\
\hline Tier I regulatory capital to risk-weighted assets & 30.2 & 31.7 & 32.7 & 29.0 & 26.1 & $\ldots$ & & $\ldots$ & $\ldots$ & $\ldots$ & $\ldots$ & $\ldots$ \\
\hline Capital (net worth) to assets & 17.8 & 21.5 & 22.9 & 22.5 & 22.7 & 22.1 & 22.5 & 23.0 & 21.2 & 22.3 & 21.0 & 21.0 \\
\hline \multirow{2}{*}{\multicolumn{13}{|c|}{$\begin{array}{l}\text { Asset composition } \\
\text { Sectoral distribution of loans (billions of drams) }\end{array}$}} \\
\hline & & & & & & & & & & & & \\
\hline Industry (excluding energy sector) & 29.0 & 30.4 & 34.3 & 49.1 & 57.4 & 59.9 & 65.7 & 66.2 & 78.0 & 76.0 & 89.6 & 115.3 \\
\hline Energy sector & 6.6 & 8.7 & 5.0 & 7.2 & 7.4 & 8.3 & 18.5 & 19.7 & 17.3 & 18.6 & 26.7 & 31.7 \\
\hline Agriculture & 8.6 & 11.3 & 14.2 & 22.4 & 24.1 & 30.3 & 31.7 & 36.5 & 44.6 & 45.9 & 45.2 & 44.2 \\
\hline Construction & 5.3 & 7.9 & 11.5 & 22.0 & 25.6 & 31.7 & 37.4 & 39.5 & 43.3 & 44.0 & 48.9 & 54.1 \\
\hline Transport and communication & 1.2 & 3.7 & 3.9 & 5.8 & 7.1 & 10.6 & 9.8 & 10.2 & 10.3 & 9.8 & 14.7 & 15.4 \\
\hline $\begin{array}{l}\text { Trade/commerce } \\
\text { Sectoral distribution of loans to total loans (percent of total) }\end{array}$ & 31.1 & 42.2 & 49.6 & 86.8 & 97.6 & 109.6 & 126.0 & 132.0 & 140.4 & 131.0 & 143.6 & 145.5 \\
\hline Industry (excluding energy sector) & 22.2 & 17.0 & 16.2 & 11.9 & 12.4 & 11.3 & 11.1 & 10.7 & 12.2 & 12.5 & 13.7 & 16.5 \\
\hline Energy sector & 5.0 & 4.8 & 2.3 & 1.7 & 1.6 & 1.6 & 3.1 & 3.2 & 2.7 & 3.1 & 4.1 & 4.5 \\
\hline Agriculture & 6.6 & 6.3 & 6.7 & 5.4 & 5.2 & 5.7 & 5.3 & 5.9 & 7.0 & 7.6 & 6.9 & 6.3 \\
\hline Construction & 4.0 & 4.4 & 5.5 & 5.3 & 5.5 & 6.0 & 6.3 & 6.4 & 6.8 & 7.3 & 7.5 & 7.7 \\
\hline Transport and communication & 0.9 & 2.0 & 1.9 & 1.4 & 1.5 & 2.0 & 1.6 & 1.7 & 1.6 & 1.6 & 2.2 & 2.2 \\
\hline Trade/commerce & 23.8 & 23.5 & 23.4 & 21.1 & 21.1 & 20.8 & 21.2 & 21.4 & 22.0 & 21.6 & 22.0 & 20.8 \\
\hline Foreign exchange loans to total loans & 70.4 & 63.7 & 52.8 & 40.7 & 39.0 & 37.5 & 38.2 & 38.7 & 48.7 & 51.5 & 54.3 & 54.0 \\
\hline \multicolumn{13}{|l|}{ Asset quality } \\
\hline Nonperforming loans (billions of drams) & 3.1 & 3.8 & 6.0 & 10.3 & 18.7 & 19.2 & 23.3 & 27.9 & 50.2 & 64.6 & 64.5 & 36.3 \\
\hline Watch (up to 90 days past due) & 1.5 & 2.9 & 3.6 & 5.8 & 13.3 & 11.9 & 13.3 & 21.8 & 36.6 & 38.8 & 27.0 & 14.9 \\
\hline Substandard (91-180 days past due) & 0.4 & 0.5 & 1.0 & 1.3 & 2.0 & 4.8 & 2.8 & 3.4 & 11.4 & 19.3 & 23.2 & 10.1 \\
\hline Doubfful (181-270 days past due) & 1.1 & 0.5 & 1.4 & 3.1 & 3.3 & 2.6 & 7.2 & 2.7 & 2.1 & 6.5 & 14.3 & 11.3 \\
\hline Loss ( $>270$ days past due) & & & & 10.1 & 9.7 & 9.4 & 10.0 & 10.2 & 12.7 & 14.3 & 20.9 & 26.2 \\
\hline Nonperforming loans to gross loans & 2.1 & 1.9 & 2.5 & 2.4 & 4.0 & 3.6 & 3.9 & 4.4 & 7.6 & 10.2 & 9.3 & 4.8 \\
\hline Provisions to nonperforming loans & 77.0 & 70.7 & 64.3 & 66.6 & 43.9 & 46.4 & 50.1 & 38.2 & 26.9 & 26.6 & 33.1 & 46.7 \\
\hline Spread between highest and lowest rates of interbank borrowing in AMD & 2.0 & 3.7 & 3.0 & 0.5 & 5.0 & 7.0 & 8.0 & 3.0 & 4.5 & 5.0 & 7.0 & 2.5 \\
\hline Spread between highest and lowest rates of interbank borrowing in foreign currency & 1.0 & 1.0 & 2.3 & 0.0 & 0.0 & 0.0 & 0.0 & 1.0 & 8.0 & 11.3 & 5.8 & 3.0 \\
\hline \multicolumn{13}{|l|}{ Earnings and profitability } \\
\hline ROA (profits to period average assets) & 3.2 & 3.1 & 3.6 & 3.4 & 3.0 & 2.8 & 2.9 & 3.1 & -0.1 & -0.1 & 0.0 & 0.7 \\
\hline ROE (profits to period average equity) & 18.4 & 15.5 & 15.9 & 15.0 & 13.0 & 12.4 & 13.1 & 13.6 & -0.7 & -0.3 & 0.1 & 3.4 \\
\hline Interest margin to gross income & 44.2 & 41.1 & 47.1 & 47.9 & 48.8 & 48.2 & 47.7 & 45.9 & 47.1 & 44.4 & 42.2 & 42.2 \\
\hline Interest income to gross income & 63.7 & 59.8 & 66.3 & 68.6 & 74.4 & 74.0 & 73.4 & 72.7 & 86.2 & 83.0 & 79.5 & 78.3 \\
\hline Noninterest expenses to gross income & 46.5 & 49.7 & 45.1 & 44.5 & 42.1 & 43.5 & 41.0 & 42.0 & 45.3 & 44.1 & 41.5 & 40.7 \\
\hline \multicolumn{13}{|l|}{ Liquidity } \\
\hline Liquid assets to total assets & 47.1 & 44.2 & 41.2 & 33.7 & 30.5 & 27.1 & 25.5 & 23.8 & 29.1 & 32.0 & 35.2 & 34.2 \\
\hline Liquid assets to total short-term liabilities & 98.7 & 110.5 & 106.1 & 98.2 & 101.0 & 95.6 & 92.4 & 103.1 & 135.4 & 145.3 & 146.2 & 142.1 \\
\hline Customer deposits to total (non-interbank) loans & 177.3 & 140.5 & 130.8 & 106.2 & 96.4 & 91.4 & 87.5 & 81.4 & 92.1 & 96.3 & 100.7 & 96.4 \\
\hline Foreign exchange liabilities to total liabilities & 73.3 & 66.8 & 56.0 & 48.3 & 48.7 & 50.0 & 50.2 & 55.1 & 69.4 & 70.9 & 68.9 & 67.6 \\
\hline \multicolumn{13}{|l|}{ Sensitivity to market risk } \\
\hline Gross open positions in foreign exchange to capital & 7.4 & 4.9 & 4.4 & 8.8 & 6.9 & 4.8 & 4.1 & 11.5 & 13.8 & 8.4 & 7.1 & 3.4 \\
\hline
\end{tabular}

Source: Central Bank of Armenia 
Table 5. Armenia: Central Government Operations, 2008-10

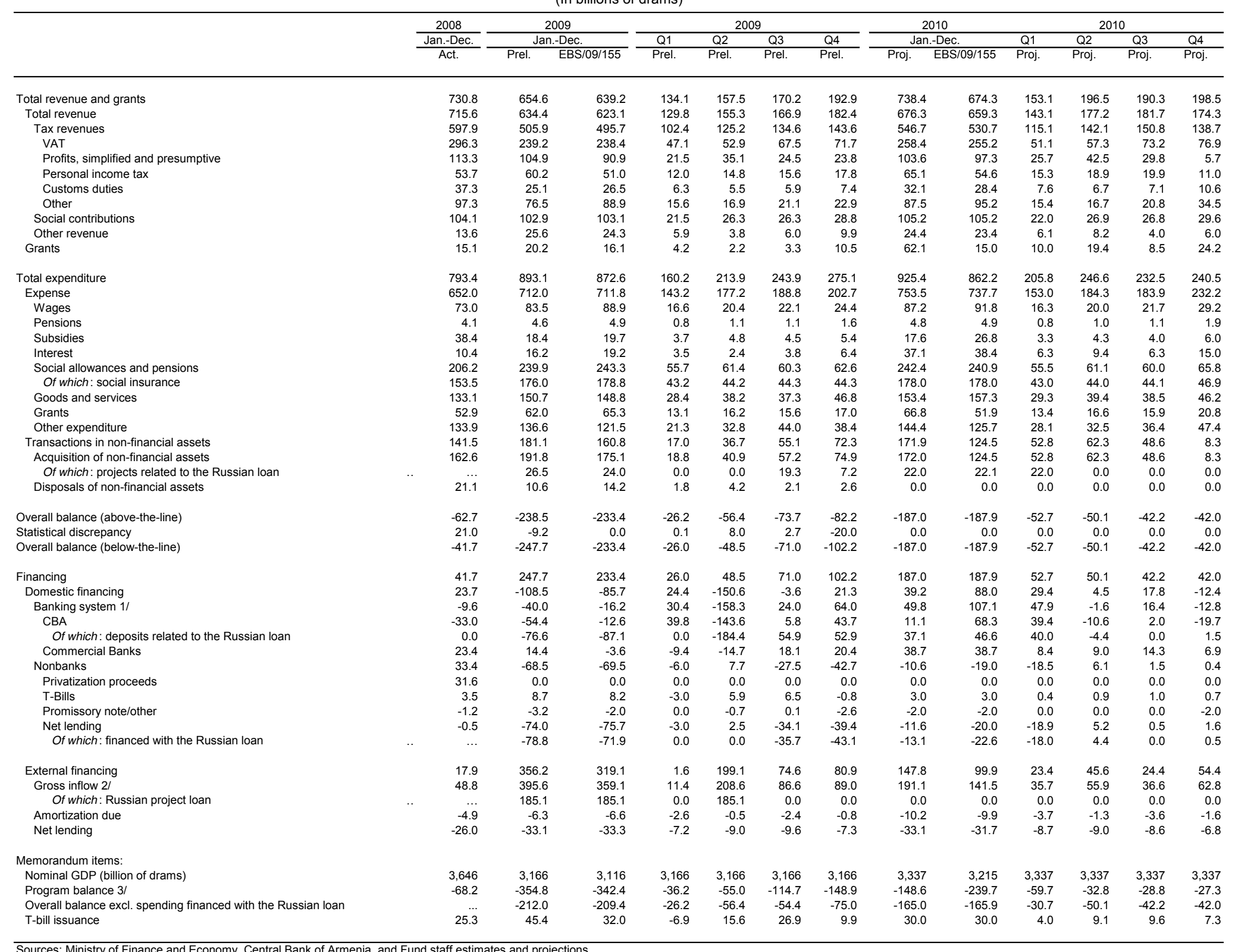

Sources: Ministry of Finance and Economy, Central Bank of Armenia, and Fund staff estimates and projections.

1/ Discrepancy between the fiscal and monetary accounts in 2009Q3-Q4, 2010Q1 is explained by government lending to the economy through commercial banks.

3/ The program balance until 2009 is measured as below-the-line overall balance minus net lending. From 2010 (Proj.), it is measured as in 2009 less project financing. 
Table 6. Armenia: Central Government Operations, 2008-10 (In percent of GDP, unless otherwise specified)

\begin{tabular}{|c|c|c|c|c|c|c|c|c|c|c|c|c|c|}
\hline & \multirow{3}{*}{$\frac{2008}{\frac{\text { Jan.-Dec. }}{\text { Act. }}}$} & \multicolumn{2}{|c|}{2009} & \multicolumn{4}{|c|}{2009} & \multicolumn{2}{|c|}{2010} & \multicolumn{4}{|c|}{2010} \\
\hline & & \multirow{2}{*}{\multicolumn{2}{|c|}{\begin{tabular}{l}
\multicolumn{2}{c}{ Jan.-Dec. } \\
Prel. EBS/09/155
\end{tabular}}} & \multirow{2}{*}{$\begin{array}{l}\text { Q1 } \\
\text { Prel. }\end{array}$} & \multirow{2}{*}{$\begin{array}{c}\text { Q2 } \\
\text { Prel. }\end{array}$} & \multirow{2}{*}{$\begin{array}{l}\text { Q3 } \\
\text { Prel. }\end{array}$} & \multirow{2}{*}{$\begin{array}{l}\text { Q4 } \\
\text { Prel. }\end{array}$} & \multirow{2}{*}{\multicolumn{2}{|c|}{$\begin{array}{l}\text { Jan.-Dec. } \\
\text { Proj. }\end{array}$}} & \multirow{2}{*}{$\begin{array}{l}\text { Q1 } \\
\text { Proj. }\end{array}$} & \multirow{2}{*}{$\begin{array}{l}\text { Q2 } \\
\text { Proj. }\end{array}$} & \multirow{2}{*}{$\begin{array}{c}\text { Q3 } \\
\text { Proj. }\end{array}$} & \multirow{2}{*}{$\begin{array}{l}\text { Q4 } \\
\text { Proj. }\end{array}$} \\
\hline & & & & & & & & & & & & & \\
\hline Total revenue and grants & 20.0 & 20.7 & 20.5 & 4.2 & 5.0 & 5.4 & 6.1 & 22.1 & 21.0 & 4.6 & 5.9 & 5.7 & 5.9 \\
\hline Total revenue & 19.6 & 20.0 & 20.0 & 4.1 & 4.9 & 5.3 & 5.8 & 20.3 & 20.5 & 4.3 & 5.3 & 5.4 & 5.2 \\
\hline Tax revenues & 16.4 & 16.0 & 15.9 & 3.2 & 4.0 & 4.3 & 4.5 & 16.4 & 16.5 & 3.4 & 4.3 & 4.5 & 4.2 \\
\hline VAT & 8.1 & 7.6 & 7.7 & 1.5 & 1.7 & 2.1 & 2.3 & 7.7 & 7.9 & 1.5 & 1.7 & 2.2 & 2.3 \\
\hline Profits, simplified and presumptive & 3.1 & 3.3 & 2.9 & 0.7 & 1.1 & 0.8 & 0.8 & 3.1 & 3.0 & 0.8 & 1.3 & 0.9 & 0.2 \\
\hline Personal income tax & 1.5 & 1.9 & 1.6 & 0.4 & 0.5 & 0.5 & 0.6 & 1.9 & 1.7 & 0.5 & 0.6 & 0.6 & 0.3 \\
\hline Customs duties & 1.0 & 0.8 & 0.9 & 0.2 & 0.2 & 0.2 & 0.2 & 1.0 & 0.9 & 0.2 & 0.2 & 0.2 & 0.3 \\
\hline Other & 2.7 & 2.4 & 2.9 & 0.5 & 0.5 & 0.7 & 0.7 & 2.6 & 3.0 & 0.5 & 0.5 & 0.6 & 1.0 \\
\hline Social contributions & 2.9 & 3.3 & 3.3 & 0.7 & 0.8 & 0.8 & 0.9 & 3.2 & 3.3 & 0.7 & 0.8 & 0.8 & 0.9 \\
\hline Other revenue & 0.4 & 0.8 & 0.8 & 0.2 & 0.1 & 0.2 & 0.3 & 0.7 & 0.7 & 0.2 & 0.2 & 0.1 & 0.2 \\
\hline Grants & 0.4 & 0.6 & 0.5 & 0.1 & 0.1 & 0.1 & 0.3 & 1.9 & 0.5 & 0.3 & 0.6 & 0.3 & 0.7 \\
\hline Total expenditure & 21.8 & 28.2 & 28.0 & 5.1 & 6.8 & 7.7 & 8.7 & 27.7 & 26.8 & 6.2 & 7.4 & 7.0 & 7.2 \\
\hline Expense & 17.9 & 22.5 & 22.8 & 4.5 & 5.6 & 6.0 & 6.4 & 22.6 & 22.9 & 4.6 & 5.5 & 5.5 & 7.0 \\
\hline Wages & 2.0 & 2.6 & 2.9 & 0.5 & 0.6 & 0.7 & 0.8 & 2.6 & 2.9 & 0.5 & 0.6 & 0.7 & 0.9 \\
\hline Pensions & 0.1 & 0.1 & 0.2 & 0.0 & 0.0 & 0.0 & 0.1 & 0.1 & 0.2 & 0.0 & 0.0 & 0.0 & 0.1 \\
\hline Subsidies & 1.1 & 0.6 & 0.6 & 0.1 & 0.2 & 0.1 & 0.2 & 0.5 & 0.8 & 0.1 & 0.1 & 0.1 & 0.2 \\
\hline Interest & 0.3 & 0.5 & 0.6 & 0.1 & 0.1 & 0.1 & 0.2 & 1.1 & 1.2 & 0.2 & 0.3 & 0.2 & 0.4 \\
\hline Social allowances and pensions & 5.7 & 7.6 & 7.8 & 1.8 & 1.9 & 1.9 & 2.0 & 7.3 & 7.5 & 1.7 & 1.8 & 1.8 & 2.0 \\
\hline Of which: social insurance & 4.2 & 5.6 & 5.7 & 1.4 & 1.4 & 1.4 & 1.4 & 5.3 & 5.5 & 1.3 & 1.3 & 1.3 & 1.4 \\
\hline Goods and services & 3.7 & 4.8 & 4.8 & 0.9 & 1.2 & 1.2 & 1.5 & 4.6 & 4.9 & 0.9 & 1.2 & 1.2 & 1.4 \\
\hline Grants & 1.5 & 2.0 & 2.1 & 0.4 & 0.5 & 0.5 & 0.5 & 2.0 & 1.6 & 0.4 & 0.5 & 0.5 & 0.6 \\
\hline Other expenditure & 3.7 & 4.3 & 3.9 & 0.7 & 1.0 & 1.4 & 1.2 & 4.3 & $\begin{array}{l}3.0 \\
3.9\end{array}$ & 0.8 & 1.0 & 1.1 & 1.4 \\
\hline Transactions in non-financial assets & 3.9 & 5.7 & 5.2 & 0.5 & 1.2 & 1.7 & 2.3 & 5.2 & 3.9 & 1.6 & 1.9 & 1.5 & 0.2 \\
\hline Acquisition of non-financial assets & 4.5 & 6.1 & 5.6 & 0.6 & 1.3 & 1.8 & 2.4 & 5.2 & 3.9 & 1.6 & 1.9 & 1.5 & 0.2 \\
\hline Of which: projects related to the Russian loan & & 0.8 & 0.8 & 0.0 & 0.0 & 0.6 & 0.2 & 0.7 & 0.7 & 0.7 & 0.0 & 0.0 & 0.0 \\
\hline Disposals of non-financial assets & 0.6 & 0.3 & 0.5 & 0.1 & 0.1 & 0.1 & 0.1 & 0.0 & 0.0 & 0.0 & 0.0 & 0.0 & 0.0 \\
\hline Overall balance (above-the-line) & -1.7 & -7.5 & -7.5 & -0.8 & -1.8 & -2.3 & -2.6 & -5.6 & -5.8 & -1.6 & -1.5 & -1.3 & -1.3 \\
\hline Statistical discrepancy & 0.6 & -0.3 & 0.0 & 0.0 & 0.3 & 0.1 & -0.6 & 0.0 & 0.0 & 0.0 & 0.0 & 0.0 & 0.0 \\
\hline Overall balance (below-the-line) & -1.1 & -7.8 & -7.5 & -0.8 & -1.5 & -2.2 & -3.2 & -5.6 & -5.8 & -1.6 & -1.5 & -1.3 & -1.3 \\
\hline Financing & 1.1 & 7.8 & 7.5 & 0.8 & 1.5 & 2.2 & 3.2 & 5.6 & 5.8 & 1.6 & 1.5 & 1.3 & 1.3 \\
\hline Domestic financing & 0.7 & -3.4 & -2.8 & 0.8 & -4.8 & -0.1 & 0.7 & 1.2 & 2.7 & 0.9 & 0.1 & 0.5 & -0.4 \\
\hline Banking system 1/ & -0.3 & -1.3 & -0.5 & 1.0 & -5.0 & 0.8 & 2.0 & 1.5 & 3.3 & 1.4 & 0.0 & 0.5 & -0.4 \\
\hline CBA & -0.9 & -1.7 & -0.4 & 1.3 & -4.5 & 0.2 & 1.4 & 0.3 & 2.1 & 1.2 & -0.3 & 0.1 & -0.6 \\
\hline Of which: deposits related to the Russian loan & & -2.4 & -2.8 & 0.0 & -5.8 & 1.7 & 1.7 & 1.1 & 1.5 & 1.2 & -0.1 & 0.0 & 0.0 \\
\hline Commercial Banks & 0.6 & 0.5 & -0.1 & -0.3 & $\begin{array}{l}-0.0 \\
-0.5\end{array}$ & 0.6 & 0.6 & 1.2 & 1.2 & 0.3 & 0.3 & 0.4 & 0.2 \\
\hline Nonbanks & 0.9 & -2.2 & -2.2 & -0.2 & 0.2 & -0.9 & -1.3 & -0.3 & -0.6 & -0.6 & 0.2 & 0.0 & 0.0 \\
\hline Privatization proceeds & 0.9 & 0.0 & 0.0 & 0.0 & 0.0 & 0.0 & 0.0 & 0.0 & 0.0 & 0.0 & 0.0 & 0.0 & 0.0 \\
\hline T-Bills & 0.1 & 0.3 & 0.3 & -0.1 & 0.2 & 0.2 & 0.0 & 0.1 & 0.1 & 0.0 & 0.0 & 0.0 & 0.0 \\
\hline Promissory note/other & 0.0 & -0.1 & -0.1 & 0.0 & 0.0 & 0.0 & -0.1 & -0.1 & -0.1 & 0.0 & 0.0 & 0.0 & -0.1 \\
\hline Net lending & 0.0 & $\begin{array}{l}-0.1 \\
-2.3\end{array}$ & -2.4 & -0.1 & 0.1 & -1.1 & -1.2 & -0.3 & -0.6 & -0.6 & 0.2 & 0.0 & 0.0 \\
\hline Of which: financed with the Russian loan & $\ldots$ & -2.5 & -2.3 & 0.0 & 0.0 & -1.1 & -1.4 & -0.4 & -0.7 & -0.5 & 0.1 & 0.0 & 0.0 \\
\hline External financing & 0.5 & 11.3 & 10.2 & 0.1 & 6.3 & 2.4 & 2.6 & 4.4 & 3.1 & 0.7 & 1.4 & 0.7 & 1.6 \\
\hline Gross inflow 21 & 1.3 & 12.5 & 11.5 & 0.4 & 6.6 & 2.7 & 2.8 & 5.7 & 4.4 & 1.1 & 1.7 & 1.1 & 1.9 \\
\hline Of which: Russian project loan & & 5.8 & 5.9 & 0.0 & 5.8 & 0.0 & 0.0 & 0.0 & 0.0 & 0.0 & 0.0 & 0.0 & 0.0 \\
\hline Amortization due & -0.1 & -0.2 & -0.2 & -0.1 & 0.0 & -0.1 & 0.0 & -0.3 & -0.3 & -0.1 & 0.0 & -0.1 & 0.0 \\
\hline Net lending & -0.7 & -1.0 & -1.1 & -0.2 & -0.3 & -0.3 & -0.2 & -1.0 & -1.0 & -0.3 & -0.3 & -0.3 & -0.2 \\
\hline Memorandum items: & & & & & & & & & & & & & \\
\hline Nominal GDP (billion of drams) & 3,646 & 3,166 & 3,116 & 3,166 & 3,166 & 3,166 & 3,166 & 3,337 & 3,215 & 3,337 & 3,337 & 3,337 & 3,337 \\
\hline Program balance $3 /$ & -1.9 & -11.2 & -11.0 & -1.1 & -1.7 & -3.6 & -4.7 & -4.5 & -7.5 & -1.8 & -1.0 & -0.9 & -0.8 \\
\hline Overall balance excl. spending financed with the Russian loan & & -6.7 & -6.7 & -0.8 & -1.8 & -1.7 & -2.4 & -4.9 & -5.2 & -0.9 & -1.5 & -1.3 & -1.3 \\
\hline T-bill issuance & 0.7 & 1.4 & 1.0 & -0.2 & 0.5 & 0.9 & 0.3 & 0.9 & 0.9 & 0.1 & 0.3 & 0.3 & 0.2 \\
\hline
\end{tabular}

Sources: Ministry of Finance and Economy, Central Bank of Armenia, and Fund staff estimates and projections.

1/ Discrepancy between the fiscal and monetary accounts in 2009Q3-Q4, 2010Q1 is explained by government lending to the economy through commercial banks.

3/ The program balance until 2009 is measured as below-the-line overall balance minus net lending. From 2010 (Proj.), it is measured as in 2009 less project financing. 
Table 7. Armenia: Public Sector Debt Sustainability Framework, 2005-15 (In percent of GDP, unless otherwise indicated)

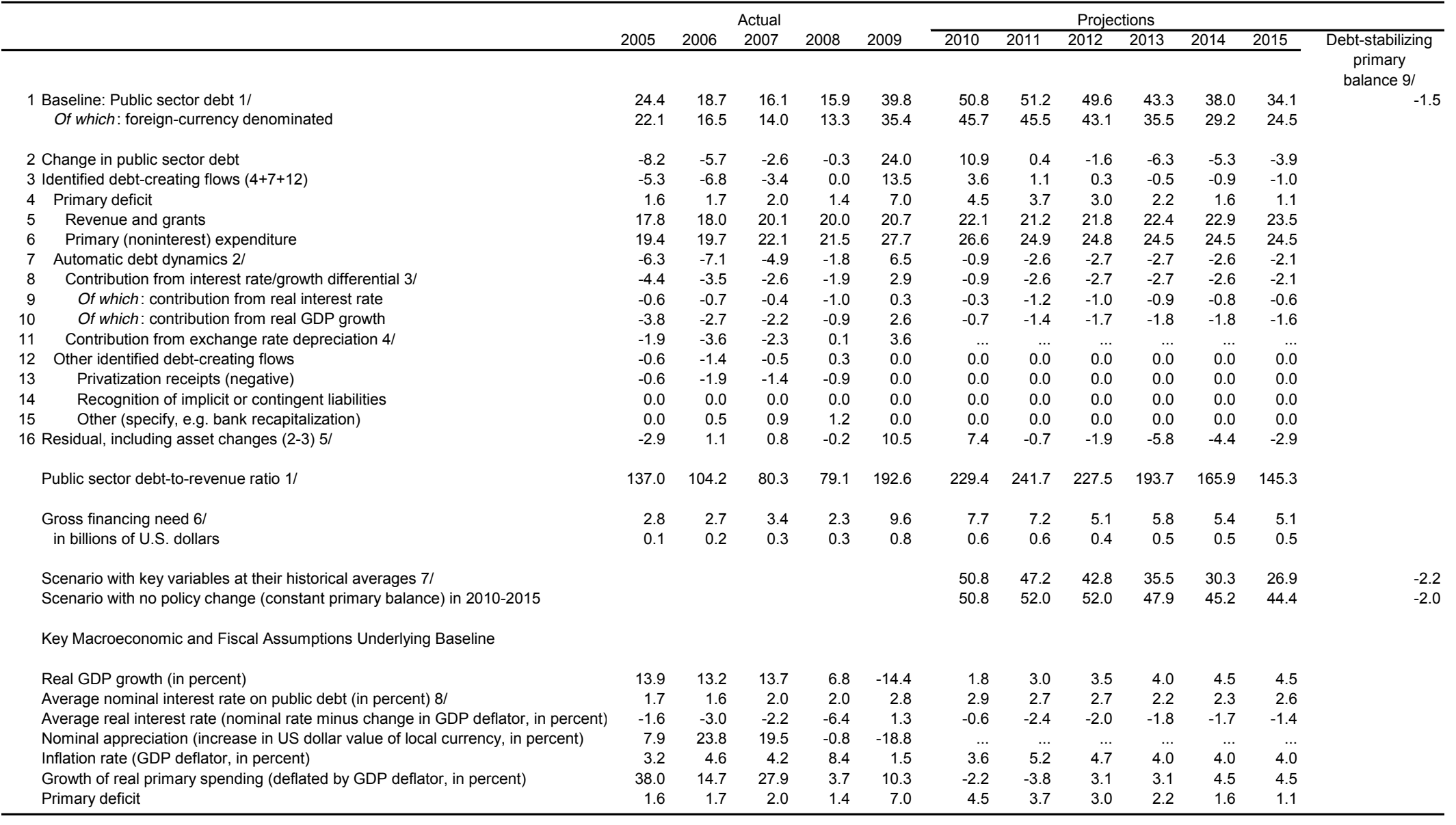

$1 /$ Indicate coverage of public sector, (e.g., general government or nonfinancial public sector). Also whether net or gross debt is used.

2/ Derived as $[(r-\pi(1+g)-g+\alpha \varepsilon(1+r)] /(1+g+\pi+g \pi))$ times previous period debt ratio, with $r=$ interest rate; $\pi=$ growth rate of GDP deflator; $g=$ real GDP growth rate; $\alpha=$ share of foreign-currency denominated debt; and $\varepsilon=$ nominal exchange rate depreciation (measured by increase in local currency value of U.S. dollar).

$3 /$ The real interest rate contribution is derived from the denominator in footnote $2 /$ as $r-\pi(1+g)$ and the real growth contribution as $-g$.

$4 /$ The exchange rate contribution is derived from the numerator in footnote $2 /$ as $\alpha \varepsilon(1+r)$.

$5 /$ For projections, this line includes exchange rate changes.

6/ Defined as public sector deficit, plus amortization of medium and long-term public sector debt, plus short-term debt at end of previous period.

7/ The key variables include real GDP growth; real interest rate; and primary balance in percent of GDP.

8/ Derived as nominal interest expenditure divided by previous period debt stock.
/ Assumes that key variables (real GDP growth, real interest rate, and other identified debt-creating flows) remain at the level of the last projection year. 
Table 8. Armenia: External Debt Sustainability Framework, 2005-15

(In percent of GDP, unless otherwise indicated)

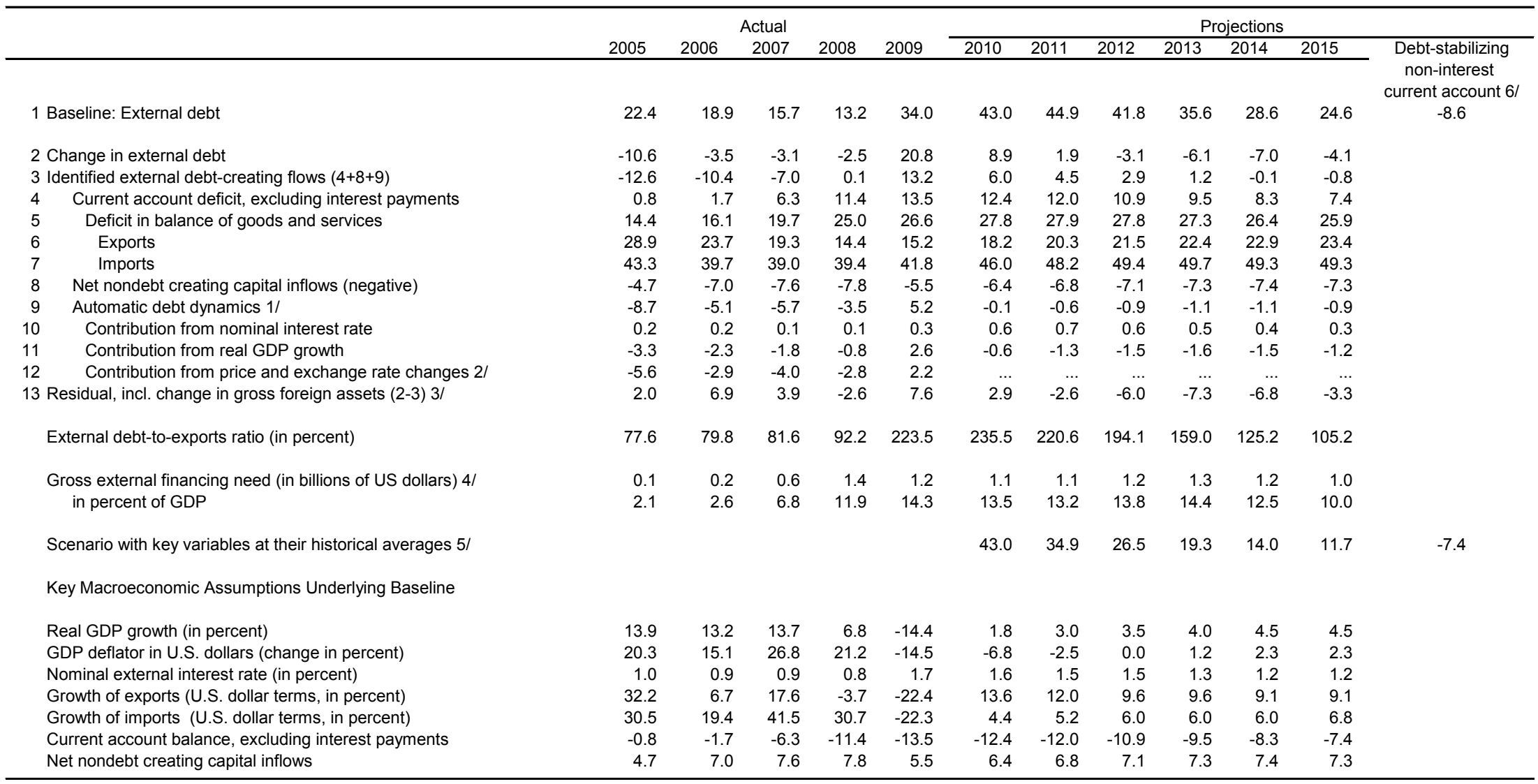

$1 /$ Derived as $[r-g-\rho(1+g)+\varepsilon \alpha(1+r)] /(1+g+\rho+g \rho)$ times previous period debt stock, with $r=$ nominal effective interest rate on external debt; $\rho=$ change in domestic GDP deflator in US dollar terms, $g=$ real GDP growth rate $\varepsilon=$ nominal appreciation (increase in dollar value of domestic currency), and $\alpha=$ share of domestic-currency denominated debt in total external debt.

$2 /$ The contribution from price and exchange rate changes is defined as $[-\rho(1+g)+\varepsilon \alpha(1+r)] /(1+g+\rho+g \rho)$ times previous period debt stock. $\rho$ increases with an appreciating domestic currency $(\varepsilon>0)$ and rising inflation (based on GDP deflator) $3 /$ For projection, line includes the impact of price and exchange rate changes.

4/ Defined as current account deficit, plus amortization on medium- and long-term debt, plus short-term debt at end of previous period.

5/ The key variables include real GDP growth; nominal interest rate; dollar deflator growth; and both non-interest current account and nondebt inflows in percent of GDP.

6/ Long-run, constant balance that stabilizes the debt ratio assuming that key variables (real GDP growth, nominal interest rate, dollar deflator growth, and non-debt inflows in percent of GDP) remain at their levels

of the last projection year. 
Table 9. Armenia: Medium-Term Macroeconomic Framework, 2007-15

(In percent of GDP, unless otherwise specified)

\begin{tabular}{|c|c|c|c|c|c|c|c|c|c|}
\hline & 2007 & 2008 & 2009 & 2010 & 2011 & 2012 & 2013 & 2014 & 2015 \\
\hline & Act. & Act. & Prel. & \multicolumn{6}{|c|}{ Projections } \\
\hline \multicolumn{10}{|l|}{ National income and prices } \\
\hline Real GDP (percent change) & 13.7 & 6.8 & -14.4 & 1.8 & 3.0 & 3.5 & 4.0 & 4.5 & 4.5 \\
\hline Gross domestic product (in millions of U.S. dollars) & 9,206 & 11,917 & 8,714 & 8,271 & 8,306 & 8,601 & 9,055 & 9,675 & 10,338 \\
\hline Gross national income per capita (in U.S. dollars) & 2,940 & 3,830 & 2,761 & 2,609 & 2,599 & 2,666 & 2,777 & 2,934 & 3,100 \\
\hline CPI inflation, end-of-period (percent change) & 6.6 & 5.2 & 6.5 & 6.2 & 4.7 & 4.0 & 4.0 & 4.0 & 4.0 \\
\hline \multicolumn{10}{|l|}{ Investment and saving } \\
\hline Investment & 38.2 & 42.8 & 36.5 & 36.5 & 35.9 & 36.4 & 36.9 & 37.4 & 37.9 \\
\hline Private & 32.9 & 38.9 & 30.8 & 31.3 & 31.8 & 32.3 & 32.8 & 33.3 & 33.8 \\
\hline Public & 5.2 & 3.9 & 5.7 & 5.2 & 4.1 & 4.1 & 4.1 & 4.1 & 4.1 \\
\hline National savings & 31.8 & 31.2 & 22.7 & 23.5 & 23.2 & 24.8 & 26.8 & 28.6 & 30.1 \\
\hline Private & 28.9 & 29.1 & 24.5 & 23.9 & 24.2 & 25.0 & 25.9 & 27.1 & 28.1 \\
\hline Public & 2.9 & 2.2 & -1.8 & -0.5 & -0.9 & -0.2 & 0.9 & 1.5 & 2.1 \\
\hline \multicolumn{10}{|l|}{ Central government operations } \\
\hline Revenue and grants & 20.1 & 20.0 & 20.7 & 22.1 & 21.2 & 21.8 & 22.4 & 22.9 & 23.5 \\
\hline Of which: tax revenue & 16.0 & 16.4 & 16.0 & 16.4 & 16.7 & 17.2 & 17.7 & 18.2 & 18.7 \\
\hline grants & 0.7 & 0.4 & 0.6 & 1.9 & 0.5 & 0.5 & 0.5 & 0.5 & 0.5 \\
\hline Expenditure & 22.4 & 21.8 & 28.2 & 27.7 & 26.1 & 26.0 & 25.5 & 25.4 & 25.4 \\
\hline Current expenditure & 17.2 & 17.9 & 22.5 & 22.6 & 22.1 & 22.0 & 21.5 & 21.4 & 21.4 \\
\hline Capital expenditure & 5.2 & 3.9 & 5.7 & 5.2 & 4.1 & 4.1 & 4.1 & 4.1 & 4.1 \\
\hline Overall balance (including grants) & -2.2 & -1.1 & -7.8 & -5.6 & -5.0 & -4.2 & -3.2 & -2.5 & -2.0 \\
\hline Domestic financing & 1.0 & 0.7 & -3.4 & 1.2 & 1.2 & 1.1 & 1.1 & 1.0 & 1.0 \\
\hline External financing & 1.2 & 0.5 & 11.3 & 4.4 & 3.8 & 3.1 & 2.1 & 1.5 & 1.0 \\
\hline Government and government-guaranteed debt & 16.1 & 15.9 & 39.8 & 50.8 & 51.2 & 49.6 & 43.3 & 38.0 & 34.1 \\
\hline \multicolumn{10}{|l|}{ External sector } \\
\hline Exports of goods and services & 19.3 & 14.4 & 15.2 & 18.2 & 20.3 & 21.5 & 22.4 & 22.9 & 23.4 \\
\hline Imports of goods and services & 39.0 & 39.4 & 42.0 & 46.0 & 48.2 & 49.4 & 49.7 & 49.3 & 49.3 \\
\hline Current account (in percent of GDP) & -6.4 & -11.5 & -13.8 & -13.0 & -12.6 & -11.6 & -10.1 & -8.8 & -7.7 \\
\hline Current account (in millions of U.S. dollars) & -589 & $-1,372$ & $-1,205$ & $-1,072$ & $-1,047$ & -994 & -913 & -847 & -800 \\
\hline Capital and financial account (in millions of U.S. dollars) & 1,191 & 1,124 & 1,318 & 970 & 915 & 971 & 947 & 1,029 & 1,014 \\
\hline Of which: direct foreign investment & 701 & 929 & 478 & 525 & 568 & 613 & 662 & 715 & 758 \\
\hline public sector disbursements & 149 & 160 & 907 & 474 & 337 & 319 & 270 & 280 & 215 \\
\hline Change in gross international reserves (in millions of U.S. dollars) 1/ & -587 & 252 & -597 & -169 & 87 & 182 & 222 & -68 & -210 \\
\hline Arrears and debt relief (in millions of U.S. dollars) & 1 & 0 & 2 & 2 & 2 & 2 & 2 & 2 & 2 \\
\hline Financing/gap (in millions of U.S. dollars) & 0 & 0 & 0 & 291 & 66 & 0 & 0 & 0 & 0 \\
\hline Of which: IMF & 0 & 0 & 0 & 291 & 56 & 0 & 0 & 0 & 0 \\
\hline Other & 0 & 0 & 0 & 0 & 10 & 0 & 0 & 0 & 0 \\
\hline Gross international reserves in months of imports & 4.2 & 4.6 & 6.3 & 6.5 & 5.9 & 5.1 & 4.2 & 4.1 & 4.4 \\
\hline
\end{tabular}

Sources: Armenian authorities; and Fund staff estimates and projections. 
Table 10. Armenia: Fund Disbursements and Timing of Reviews Under the Twenty-Eight Month Stand-By Arrangement, 2009-11 (SDR millions)

\begin{tabular}{|c|c|c|c|c|}
\hline Date of Availability & Conditions & SBA & Augmentation & Total \\
\hline 6 March, 2009 & Board approval of the Stand -By arrangement & 161.552 & & 161.552 \\
\hline \multirow[t]{2}{*}{22 June, 2009} & Observance of end -March 2009 performance criteria and completion of first review & 36.800 & & 36.800 \\
\hline & Board approval of the SBA augmentation & & 65.868 & 65.868 \\
\hline 23 October, $2009^{*}$ & Observance of end -September 2009 performance criteria and completion of second review & 37.720 & & 37.720 \\
\hline 15 February, 2010 & Observance of end -December 2009 performance criteria and completion of third review & 23.552 & 24.933 & 48.485 \\
\hline 15 May, 2010 & Observance of end -March 2010 performance criteria and completion of fourth review & 23.552 & 24.933 & 48.485 \\
\hline 15 August, 2010 & Observance of end -June 2010 performance criteria and completion of fifth review & 23.552 & 24.933 & 48.485 \\
\hline 15 November, 2010 & Observance of end -September 2010 performance criteria and completion of sixth review & 23.552 & 24.933 & 48.485 \\
\hline 15 February, 2011 & Observance of end -December 2010 performance criteria and completion of seventh review & 18.860 & & 18.860 \\
\hline 15 May, 2011 & Observance of end -March 2011 performance criteria and completion of eighth review & 18.860 & & 18.860 \\
\hline
\end{tabular}

Source: Fund staff estimates and projections.

*This review is the combination of the second and third reviews under the original program. 
Table 11. Armenia: Indicators of Capacity to Repay the Fund, 2010-15 1/

\begin{tabular}{|c|c|c|c|c|c|c|}
\hline & 2010 & 2011 & 2012 & 2013 & 2014 & 2015 \\
\hline & \multicolumn{6}{|c|}{ Projections } \\
\hline \multicolumn{7}{|l|}{$\begin{array}{l}\text { Fund obligations based on existing credit } \\
\text { (in millions of SDRs) }\end{array}$} \\
\hline Principal & 14.1 & 14.4 & 101.0 & 162.0 & 72.4 & 4.5 \\
\hline Charges and interest & 2.9 & 3.8 & 3.8 & 2.3 & 0.5 & 0.1 \\
\hline \multicolumn{7}{|l|}{$\begin{array}{l}\text { Fund obligations based on existing and prospective credit } \\
\text { (in millions of SDRs) }\end{array}$} \\
\hline Principal & 14.1 & 14.4 & 101.0 & 198.4 & 181.1 & 84.0 \\
\hline Charges and interest & 4.6 & 6.7 & 6.6 & 5.1 & 2.6 & 0.7 \\
\hline \multicolumn{7}{|l|}{ Total obligations based on existing and prospective credit } \\
\hline In millions of SDRs & 18.7 & 21.1 & 107.6 & 203.5 & 183.7 & 84.7 \\
\hline In millions of US\$ & 29.8 & 33.6 & 171.5 & 324.3 & 292.5 & 134.0 \\
\hline In percent of gross international reserves & 1.4 & 1.6 & 9.0 & 19.3 & 16.7 & 6.8 \\
\hline In percent of exports of goods and services & 2.0 & 2.0 & 9.3 & 16.0 & 13.2 & 5.5 \\
\hline In percent of debt service $2 /$ & 31.5 & 32.0 & 69.2 & 74.1 & 72.9 & 50.6 \\
\hline In percent of GDP & 0.4 & 0.4 & 2.0 & 3.6 & 3.0 & 1.3 \\
\hline In percent of quota & 20.3 & 22.9 & 117.0 & 221.2 & 199.7 & 92.1 \\
\hline \multicolumn{7}{|l|}{ Outstanding Fund credit 2/ } \\
\hline In millions of SDRs & 554.1 & 577.3 & 476.3 & 277.9 & 96.8 & 12.8 \\
\hline In billions of US\$ & 0.9 & 0.9 & 0.8 & 0.4 & 0.2 & 0.0 \\
\hline In percent of gross international reserves & 40.7 & 44.1 & 39.9 & 26.4 & 8.8 & 1.0 \\
\hline In percent of exports of goods and services & 58.5 & 54.4 & 41.0 & 21.8 & 7.0 & 0.8 \\
\hline In percent of debt service $2 /$ & 933.6 & 875.9 & 306.3 & 101.2 & 38.4 & 7.6 \\
\hline In percent of GDP & 10.7 & 11.1 & 8.8 & 4.9 & 1.6 & 0.2 \\
\hline In percent of quota & 602.2 & 627.5 & 517.8 & 302.1 & 105.2 & 13.9 \\
\hline Net use of Fund credit (millions of SDRs) & 179.8 & 23.3 & -101.0 & -198.4 & -181.1 & -84.0 \\
\hline Disbursements & 193.9 & 37.7 & 0.0 & 0.0 & 0.0 & 0.0 \\
\hline Repayments and repurchases & 14.1 & 14.4 & 101.0 & 198.4 & 181.1 & 84.0 \\
\hline \multicolumn{7}{|l|}{ Memorandum items: } \\
\hline Nominal GDP (in millions of US\$) & $8,270.6$ & $8,306.1$ & $8,600.8$ & $9,054.7$ & $9,675.2$ & $10,338.1$ \\
\hline Exports of goods and services (in millions of US\$) & $1,508.8$ & $1,689.8$ & $1,851.3$ & $2,028.3$ & $2,213.3$ & $2,415.3$ \\
\hline Gross international reserves (in millions of US\$) & $2,172.0$ & $2,085.0$ & $1,902.8$ & $1,680.3$ & $1,748.8$ & $1,958.5$ \\
\hline Debt service (in millions of US\$) 2/ & 94.6 & 105.0 & 247.8 & 437.5 & 401.5 & 265.1 \\
\hline Quota (millions of SDRs) & 92.0 & 92.0 & 92.0 & 92.0 & 92.0 & 92.0 \\
\hline
\end{tabular}

Source: Fund staff estimates and projections.

$1 /$ Indicators cover both GRA and PRGF credit.

2/ Total debt service includes IMF repurchases and repayments. 
Table 12. Armenia: Macro-Criticality of Structural Benchmarks

\begin{tabular}{|c|c|c|}
\hline Item & Measure & Rationale for Macro-Criticality \\
\hline 1 & $\begin{array}{l}\text { Tax administration } \\
\text { As a necessary condition for implementing a fully functional risk-based approach to } \\
\text { VAT refund processing, submit legislation to parliament that allows only high-risk VAT } \\
\text { refunds to be subject to review (structural benchmark for end-March 2010). } \\
\text { Adopt a government decree establishing a mechanism for implementing a fully } \\
\text { functional risk management approaches in VAT refund processing (structural } \\
\text { benchmark for end-December 2010). }\end{array}$ & $\begin{array}{l}\text { Improve the business environment by introducing best practice in modern tax } \\
\text { administration, while boosting revenue collection and ensuring the integrity of the VAT } \\
\text { system. }\end{array}$ \\
\hline 3 & $\begin{array}{l}\text { Tax and social policy } \\
\text { Submit legislation to parliament amending the Law on Presumptive Taxes to allow } \\
\text { transfer of certain types of activities identified in the Law on Presumptive Taxes to the } \\
\text { general taxation system (structural benchmark for end-September 2010). }\end{array}$ & $\begin{array}{l}\text { Develop a sustainable revenue base by increasing revenue collection, while } \\
\text { enhancing tax efficiency and equity. }\end{array}$ \\
\hline 4 & $\begin{array}{l}\text { Fiscal sustainability } \\
\text { Submit a medium-term fiscal framework (2011-13) to the government (structural } \\
\text { benchmark for end-July 2010). }\end{array}$ & $\begin{array}{l}\text { Strengthen the fiscal framework by anchoring fiscal policy in a credible and realistic } \\
\text { medium-term framework to ensure fiscal and debt sustainability over the medium- to } \\
\text { long-term. }\end{array}$ \\
\hline 5 & $\begin{array}{l}\text { Financial sector } \\
\text { Issue prudential regulations to specifically address currency-induced credit risk, } \\
\text { including increased loan-loss provisioning requirements and higher risk weights in } \\
\text { capital requirements for foreign currency loans (structural benchmark for end-June } \\
\text { 2010). }\end{array}$ & $\begin{array}{l}\text { Reduce vulnerabilities of the financial sector and enhance banks' risk management in } \\
\text { light of increased dollarization and exchange rate flexibility. }\end{array}$ \\
\hline 6 & $\begin{array}{l}\text { Formalize the Committee for Financial Stability in an MOU (structural benchmark for } \\
\text { end-September 2010). } \\
\text { Issue prudential regulation requiring banks to prepare their contingency plans } \\
\text { (structural benchmark for end-December 2010). }\end{array}$ & $\begin{array}{l}\text { Ensure financial sector stability by enhancing contingency planning and crisis } \\
\text { preparedness. }\end{array}$ \\
\hline
\end{tabular}




\section{APPENDiX: AnALYTICAL BACKGROUND}

\section{A. Price Developments in 2009 and Projections for Inflation in 2010-11}

1. End-of-period inflation in 2009 exceeded the authorities' target of $4 \pm \mathbf{1 . 5}$ percent. The component of the CPI driving inflation was in particular the rent and fuel and power (RFP) subindex, for which average inflation was 14 percent. ${ }^{1}$ Looking at other components of the CPI, transport and communication (TC) prices increased by only 2 percent, although the contribution of TC to inflation increased sharply in the last quarter of 2009, with an average year-on-year inflation of 10 percent. Food prices have been stable on average, with a period average inflation of -0.9 , but their contribution to inflation increased in the last two months of 2009 and January 2010. Medical care and recreation, entertainment, and education prices have also recently shown some pickup.

2. These price developments are largely explained by pass-through effects of the March 2009 exchange rate depreciation, developments in world commodity prices, and administrative price increases. Food price developments in Armenia are closely linked to international food prices, with a lag of approximately 3 months. The TC component of CPI shows sharp month-on-month increases in March, April, and November 2009, which are explained by world petrol prices and exchange rates since airfare is a large component of transport. RFP prices are determined by administrative tariffs. Month-on-month RFP prices spiked in May 2008 and April 2009 due to adjustments to administrative prices, but have otherwise remained constant.

3. CPI projections indicate that end-of-period inflation in 2010 will continue to exceed the authorities' target range, but will fall within the range from mid-2011 onwards. These forecasts are based on regressions of food and TC prices on world commodity prices. Given that food prices have a weight of 48 percent in the CPI basket, it is not surprising that the projected series of food price inflation predicts the direction of actual inflation in Armenia. With the exception of RFP, the average month-on-month price increase for all other CPI components over the last two years is used to estimate the month-on-month increases in 2010 and 2011. As a result of administrative tariff increases, RFP prices are assumed to show a month-on-month increase in April 2010, which is equal to the average of the month-on-month increases in May 2008 and April 2009.

\footnotetext{
${ }^{1}$ The rent in the RFP component of CPI mostly comprises utilities.
} 
Figure 1. Armenia: Inflation Developments

Year-on-year inflation in 2009 was mostly driven by rent and fuel and power (RFP), and transport and communication prices whilst food prices recently showed some pickup.

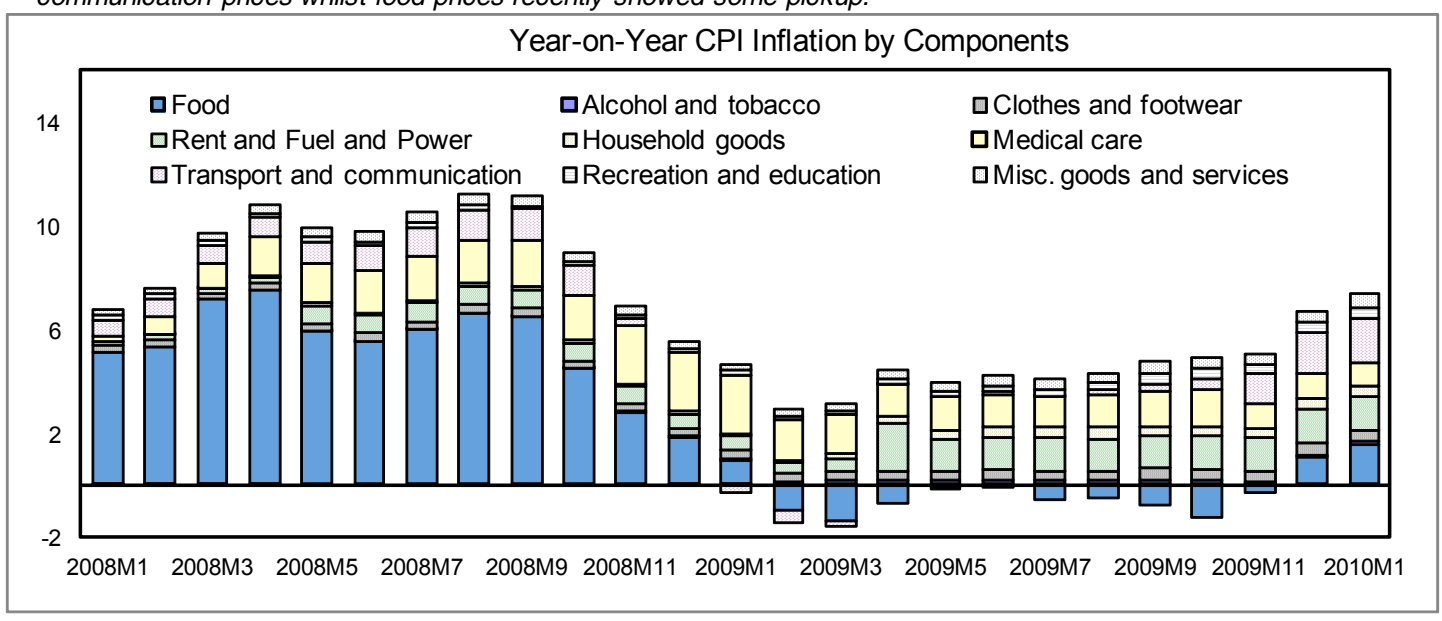

Food prices in Armenia follow world food prices closely...

...while transport and communication prices are linked to world petrol prices.
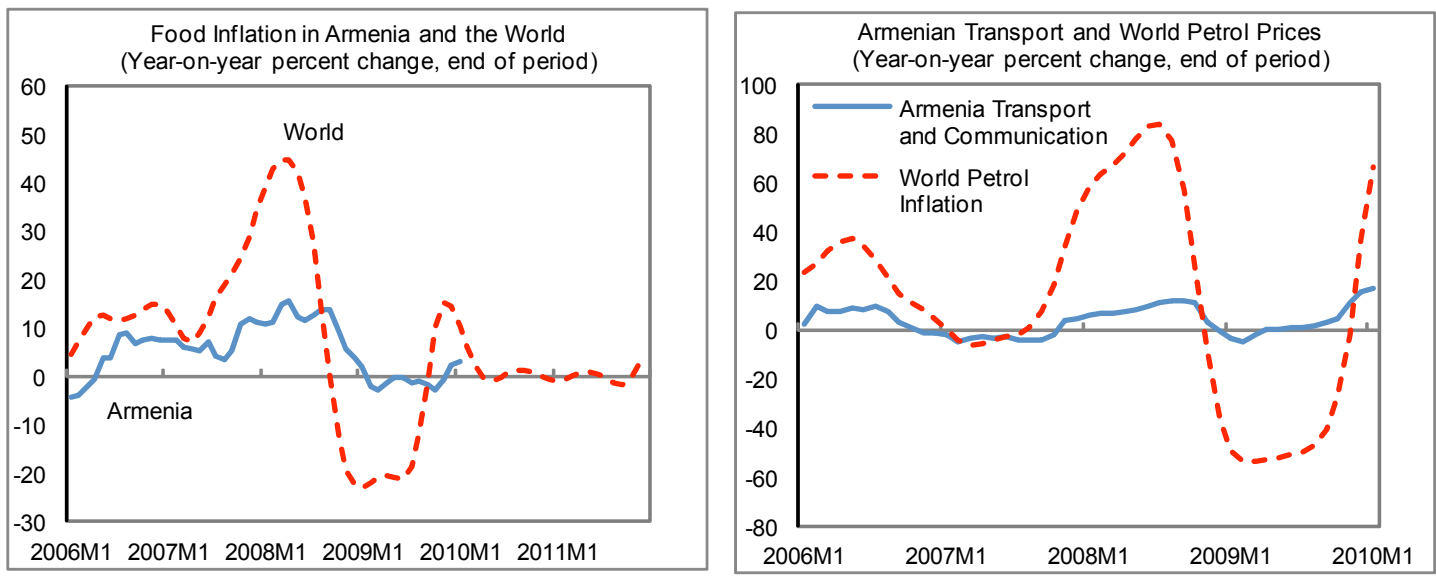

RFP prices are determined by administrative tariffs while transport and communication prices increased in March 2009 in response to the depreciation.

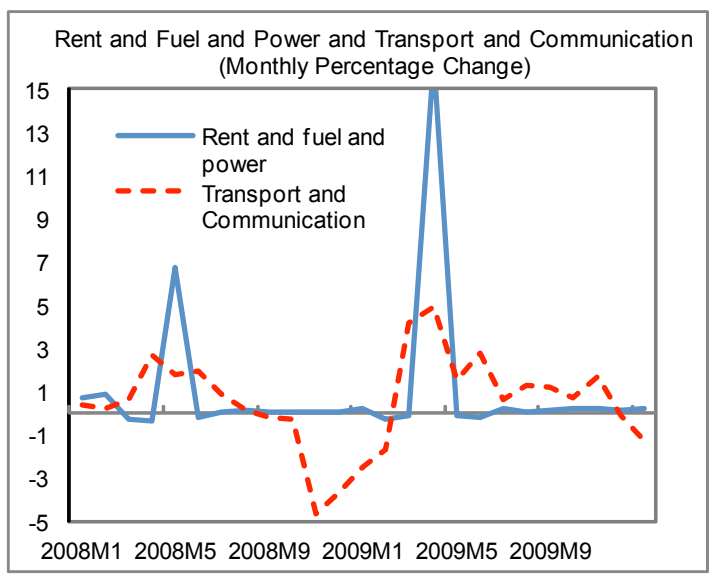

Projections of food price inflation largely explain the direction of the CPI.

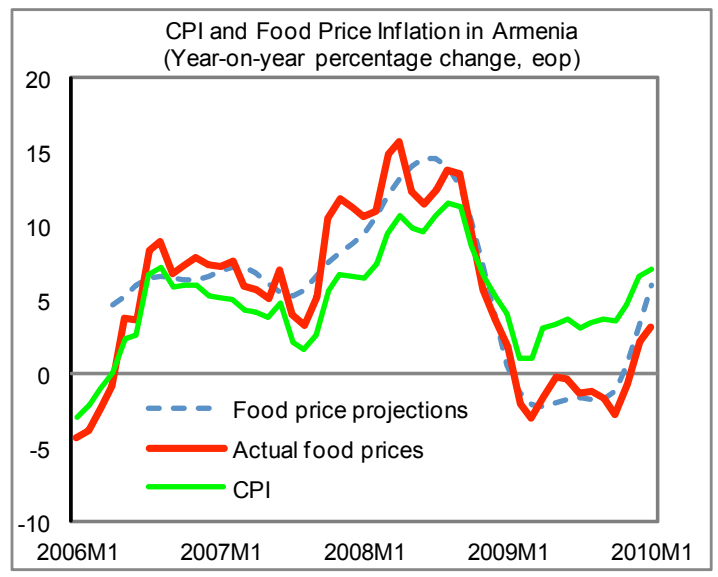

Sources: Armenian authorities, WEO, and Fund staff estimates. 


\section{B. Estimating the Output Gap and the Cyclically-Adjusted Fiscal Balance}

4. This section attempts to estimate the cyclically-adjusted fiscal balance for Armenia using estimates of the output gap based on different econometric methods: (i) the HP filter; (ii) the production function approach; (iii) a simple univariate Kalman filter; (iv) a multivariate Kalman filter; and (v) a Bayesian multivariate Kalman filter. The output gap in these estimations is measured as the percent deviation of real seasonally-adjusted GDP from its potential.

5. Armenia's GDP is estimated to have dropped below potential in 2009-10. All econometric methods show that the negative output gap in 2006 narrows considerably in 2007 and turns positive in 2008. It then becomes significantly negative in 2009 in the face of the global economic crisis. However, econometric techniques based on a variant of the Kalman filter suggest significantly less overheating of the economy in 2008 and a smaller and a less negative output gap in 2009. These differences are partly due to the end-point bias of the HP filter and the production function approach, which is based on an HP filter methodology. Another possible explanation is that the growth rate of potential GDP has not been constant over time. The Kalman filter and Bayesian methodologies treat the growth rate of potential as time-varying and are able to extract cyclical fluctuations from the data. However, as a result, potential output may see large swings. Projections based on the Kalman filter and Bayesian methodologies indicate broadly similar results, with the output gap remaining significantly negative for a number of years.
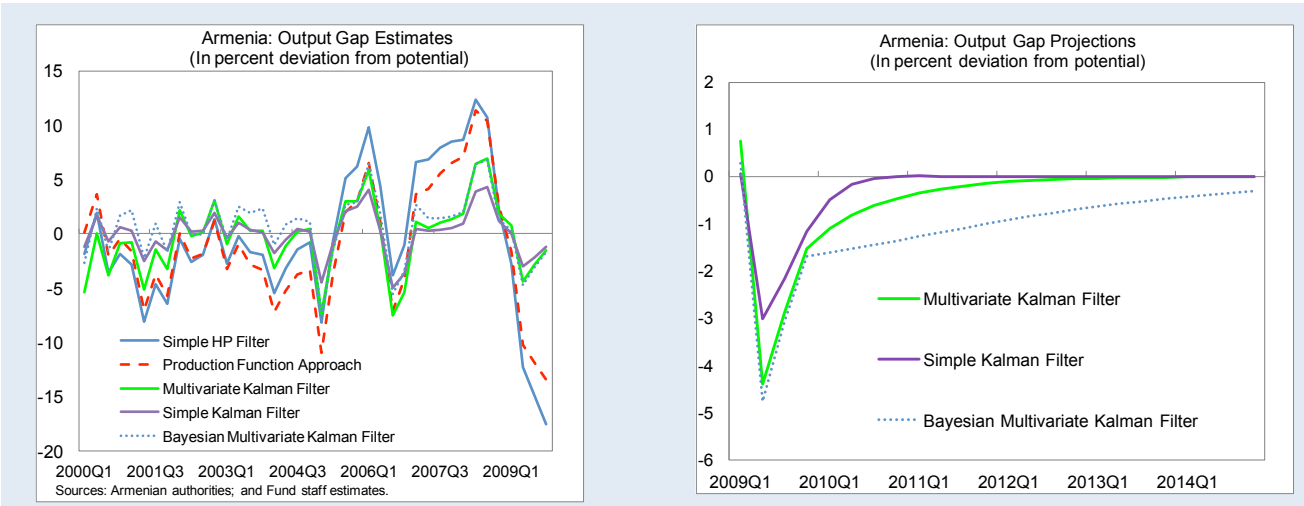

Sources: Armenian authorities; and Fund staff estimates.

6. Estimates of the underlying fiscal stance confirm that fiscal policy was expansionary in 2009 as the cyclically-adjusted primary balance shows a considerable fiscal stimulus in 2009. The deterioration in the structural primary balance in 2009 under the Kalman filter and Bayesian methodologies is about 5 percentage points of GDP on average. 
7. As output has stabilized and economic recovery is under way, fiscal policy is expected to play less of a role in boosting the country's output in 2010. With debt sustainability and financing concerns emerging, a slight tightening in the underlying fiscal stance by about 1 percent of GDP is projected for 2010. Furthermore, continued adjustment is projected over the medium term to put the fiscal position on a sustainable path.

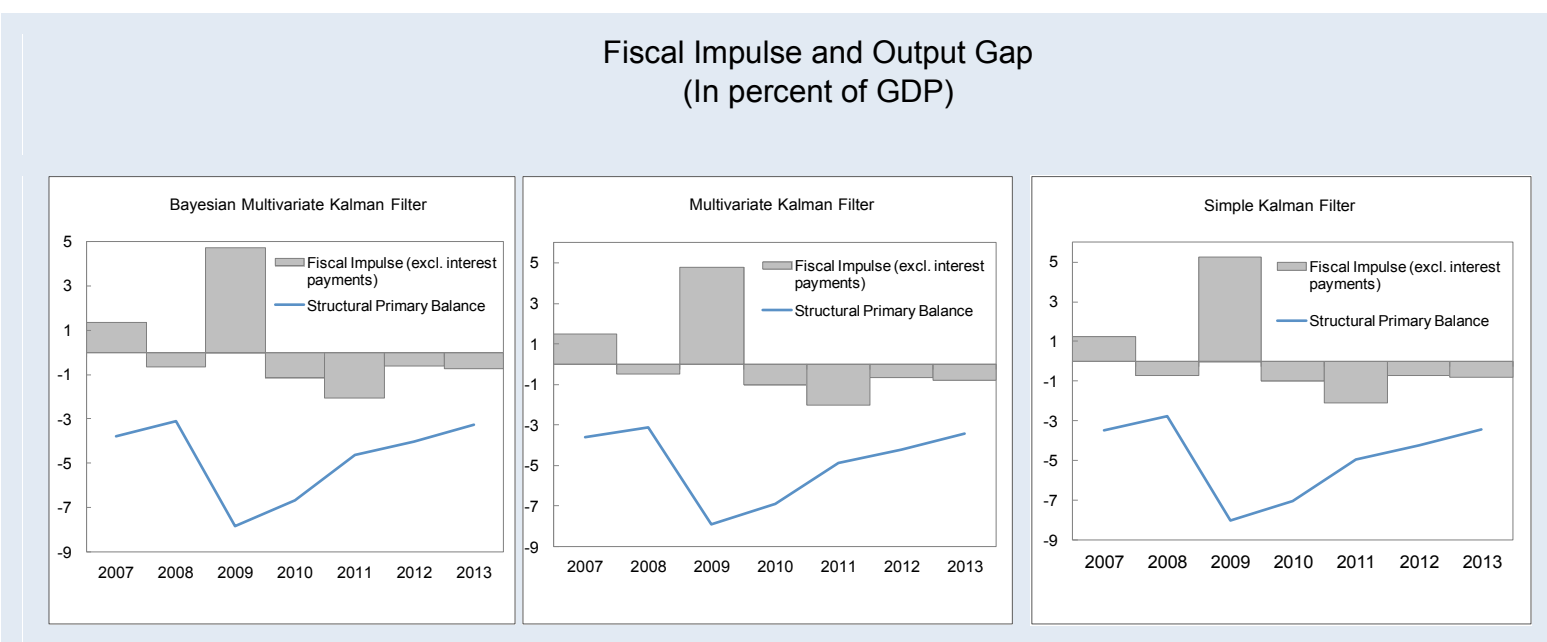

Sources: Armenian authorities; and Fund staff estimates.

8. Measures of the fiscal policy stance shown in the table below are based on the Bayesian methodology. The Bayesian methodology is the most robust of these econometric techniques because it estimates by maximum likelihood a structural model of the Armenian economy, including core inflation, GDP, and unemployment. And while there is inherently some uncertainty in such estimates, the results show the relatively large fiscal impulse in 2009 compared to the size of automatic stabilizers, which are relatively weak in Armenia. It further confirms the contractionary stance in 2010, given the output gap.

Armenia: Fiscal Policy Measurement (In percent of GDP)

\begin{tabular}{lrrrr}
\hline & 2007 & 2008 & 2009 & 2010 \\
\hline Primary balance 1/ & -3.4 & -2.2 & -8.5 & -7.1 \\
Structural primary balance 2/ & -3.8 & -3.1 & -7.8 & -6.7 \\
Cyclical primary balance 3/ & 0.4 & 0.9 & -0.6 & -0.4 \\
Automatic stabilizers 4/ & -0.4 & -0.5 & 1.5 & -0.2 \\
Fiscal impulse (excluding interest payments) 5/ & 1.4 & -0.7 & 4.7 & -1.1 \\
Output gap 6/ & 1.8 & 4.1 & -2.3 & -1.5 \\
\hline
\end{tabular}

Sources: Armenian authorities; and Fund staff estimates.

VPrimary Balance is defined as the overall balance excluding other revenues, grants, and interest payments. 2/The Structural Primary Balance is calculated assuming revenue elasticity of one and spending elasticity of zero. 3/The Cyclical Primary Balance is calculated as the difference between the primary balance and the structural primary balance. 4/First difference in the cyclical primary balance. A deterioration in the cyclical primary balance implies the operation of automatic stabilizers. 5/First difference in the structural primary balance. A deterioration in the primary structural balance implies a positive fiscal impulse. 6/The output gap is calculated using the Baeysian Multivariate Kalman Filter. 


\section{Resilience in the Banking Sector}

9. The Armenian banking sector has proved resilient to the crisis.

Substantial capital and liquidity buffers, due in part to low leverage ratios, have enabled the banking sector to absorb shocks. Despite a significant increase in NPLs and considerable losses from the dram depreciation last March, the aggregate capital adequacy ratio remained strong at 28.3 percent at end-2009, more than double the prudential minimum of 12 percent. As of end-December 2009, only 3 of the sector's 22 banks had capital ratios below 20 percent. Liquidity ratios remained well above minimum prudential requirements throughout the year. On top of an effective supervision framework, the authorities have implemented measures to help contain the negative impact of the crisis. For example, they have strengthened the financial safety nets (lender of last resort facility and deposit insurance scheme), tightened prudential regulations (reinstating foreign currency exposure limits), and encouraged capital injections to provide increased cushion through its subordinated debt facility. ${ }^{2}$

\section{Banking sector balance sheets} have imp roved since September 2009. After a marked deterioration during the first 8 months of 2009, NPLs under both the CBA and the IMF definitions have fallen to 7 percent in January 2010. Profitability improved, but remains low. Profits turned positive in September 2009

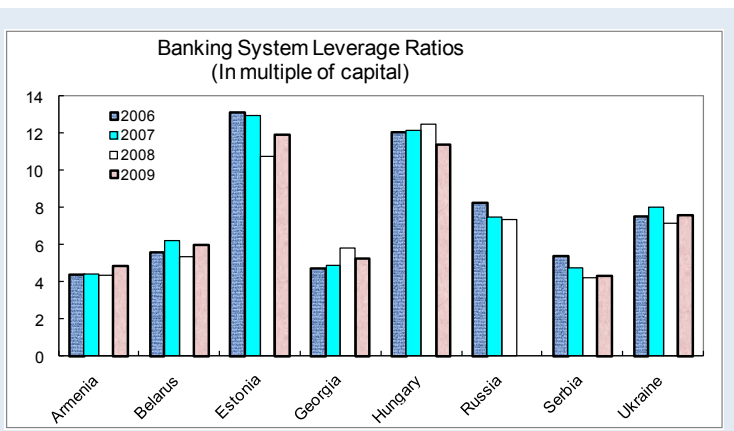

Source: GFSR. In the GFSR, leverage is depicted by the ratio of capital to total assets. Here, the leverage ratio is defined as total assets divided by capital.

for the first time since March 2009,

although the ROA and ROE at end-2009 were 0.75 and 3.4 percent respectively, still significantly less than the figures of 3.1 and 13.6 percent at end-2008.

\footnotetext{
${ }^{2}$ The CBA intends to terminate the capital injection-matching subordinated debt facility to minimize risk to its balance sheet and potential conflict of interest. In 2009, the CBA extended a total of approximately AMD 15 billion in 5-year subordinated loans under this facility to 4 banks, amounting to around 5 percent of total capital of the banking sector. These loans also helped improve banks' access to long-term funding.
} 
11. Latest stress test results indicate that banks are able to withstand a variety of shocks, thanks to the relatively high capitalization. The large capital cushion allows most banks to absorb losses and remain adequately capitalized even under extreme credit shock scenarios. Under all scenarios except for combined shocks, the CAR would decline by no more than 4 percentage points for the system as a whole. A few banks, however, appear to be more vulnerable than others to various risks, due to their relatively low capitalization level. However, the risks are contained and low, as capital injections appear to be readily available for these banks. The CBA is closely monitoring these cases.

12. However, continued vigilance is still needed as risks to balance sheets from indirect foreign currency exposure remain. Since March 2009, deposit and loan dollarization have stabilized at around 70 and 50 percent, respectively. Exposure to unhedged borrowers represents a main source of vulnerability in the banking sector, especially in light of increased exchange rate flexibility. The CBA is in the process of strengthening prudential regulations to specifically address indirect FX risks by increasing provisioning requirements and risk weights in capital requirements for foreign currency loans. This will also provide the CBA with adequate information on the extent of unhedged lending by banks to enhance supervisory monitoring.

13. In addition, efforts to

encourage banking sector

competition should continue to increase efficiency and enhance financial deepening. The high capital or low leverage in the banking sector is a source of resilience, but it has led to high interest rate spreads and hampered financial deepening. By regional standards, financial intermediation in Armenia is relatively low, with bank

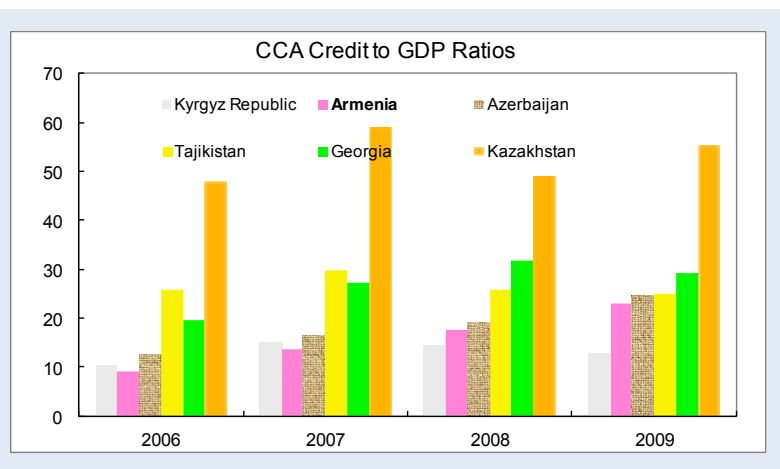

Sources: Armenian authorities; and Fund staff estimates. loans-to-GDP ratio at 22 percent in 2009, up from 17 percent in 2008 largely as a result of GDP decline. 


\section{External Debt Analysis}

14. Since the onset of the global crisis, Armenia's debt dynamics-driven by external debt, which accounts for 95 percent of public debt-have evolved, and its rapid accumulation calls for initiating fiscal consolidation over the medium term. The external debt stock, which was only 13 percent of GDP at end-2008, had almost tripled by end-2009, reaching 34 percent of GDP and is expected to peak at about 45 percent of GDP in 2011, before gradually declining over the medium term. The projected debt-to-GDP levels do not appear excessive, and standard stress tests show that Armenia's debt remains sustainable. However, rollover risk is high, mainly due to the short maturity of Fund financing with repurchase obligations during 2012-14.

15. While debt levels are manageable under the current policy scenario, the outlook is subject to risks. The standard bound tests show that the combined shocks lead to an increase in the debt-to-GDP ratio by several percentage points, to almost 50 percent of GDP. However, the effect of a real exchange rate shock is particularly pronounced, reflecting the rising weight of external debt in total public debt. 
Figure 2. Armenia: External Debt Sustainability: Bound Tests 1/

(External debt in percent of GDP)
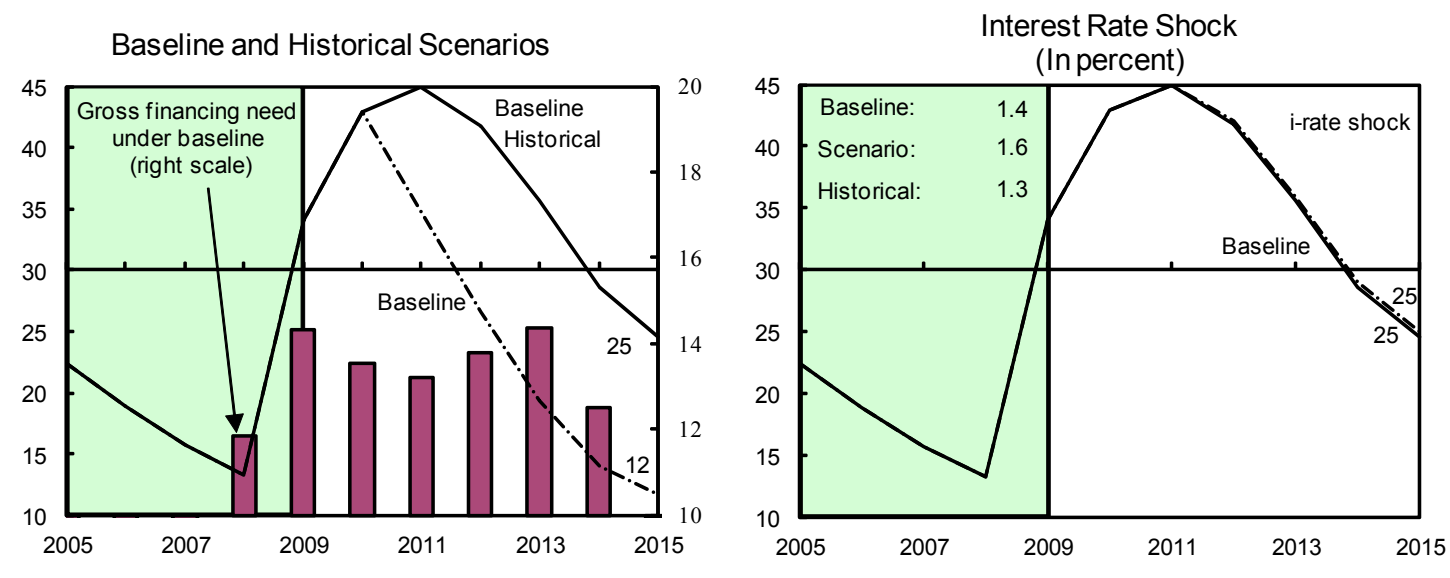

Growth Shock (In percent per year)
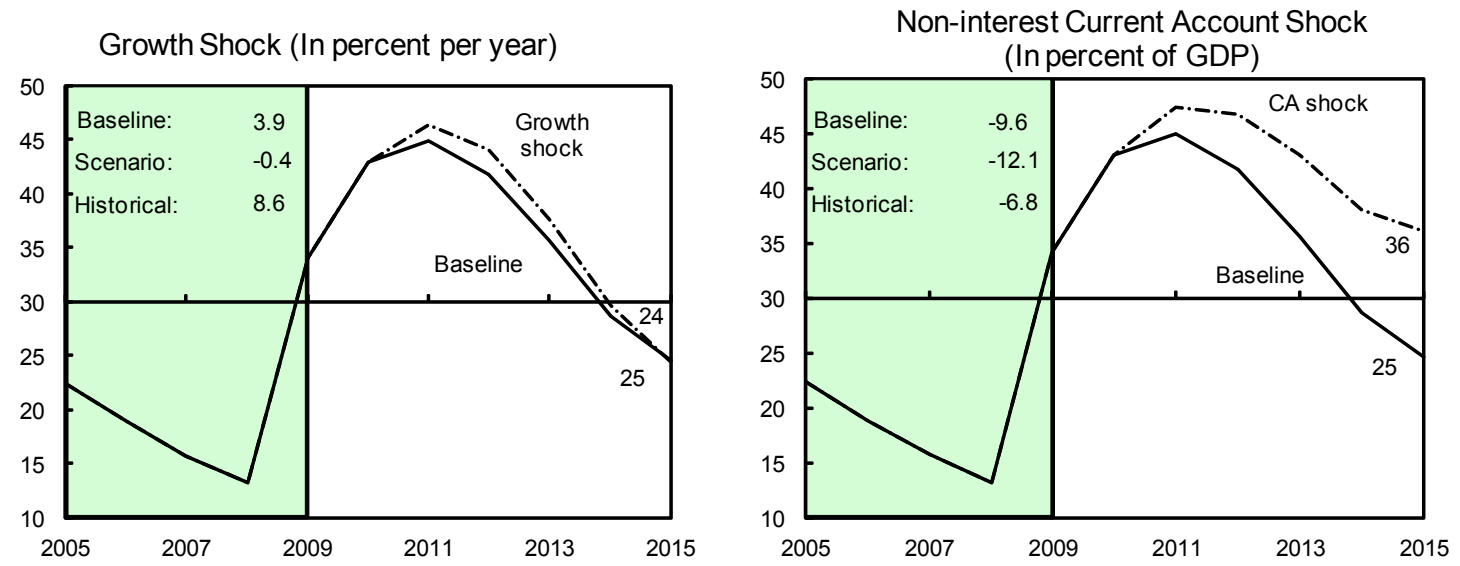

Combined Shock 2/
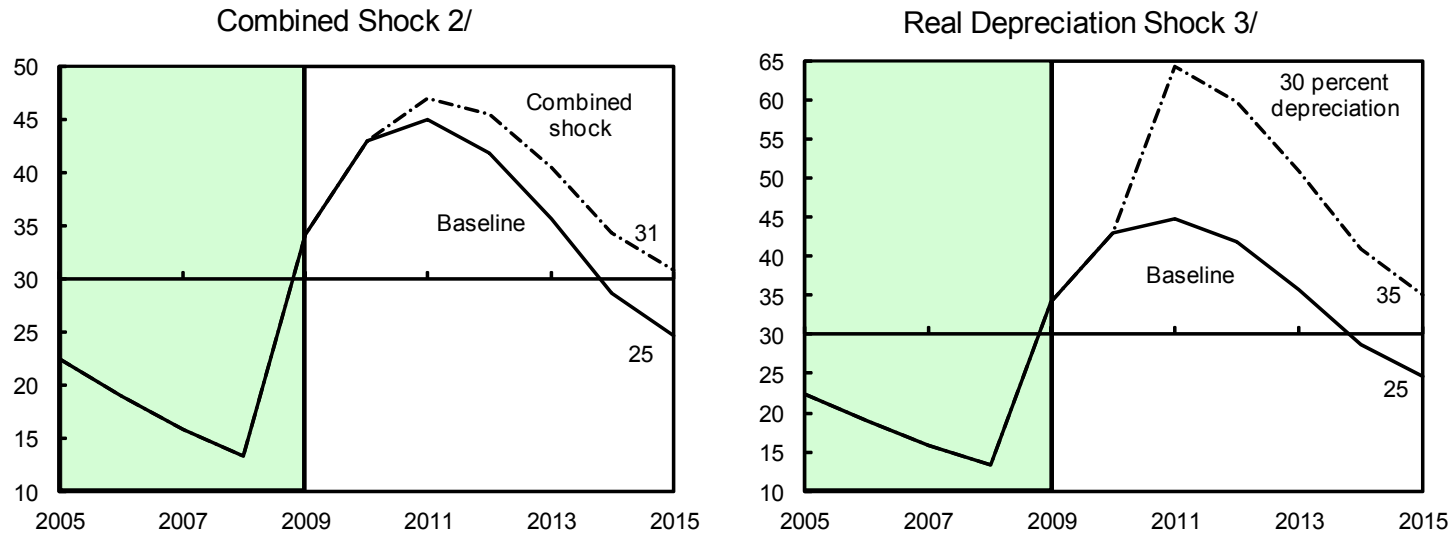

Sources: International Monetary Fund, Country desk data, and staff estimates.

1/ Shaded areas represent actual data. Individual shocks are permanent one-half standard deviation shocks. Figures in the boxes represent average projections for the respective variables in the baseline and scenario being presented. Ten-year historical average for the variable is also shown.

2/ Permanent 1/4 standard deviation shocks applied to real interest rate, growth rate, and current account balance. 3/ One-time real depreciation of 30 percent occurs in 2010. 


\section{AtTACHMEnt I. ARMENIA: LeTter OF InTENT}

March 10, 2010

Mr. Dominique Strauss-Kahn

Managing Director

International Monetary Fund

Washington, D.C. 20431

Dear Mr. Strauss-Kahn:

1. On the back of a strong policy response, Armenia is leaving behind a crisis of enormous proportions. Since the last review, our continued fiscal and monetary stimulus has stabilized the economy. Our exchange rate policy stabilized the dollarization process and has been instrumental in allaying concerns for financial stability. Structural reforms in the program are building the foundation for increased tax collection and improving safety nets to minimize the effects of the crisis on the poor.

2. Our performance under the program continues to be very strong. Almost all quantitative targets for end-December were met. The fiscal deficit, while providing key support to the economy, has been kept under control, allowing us to attain the endDecember targets for the fiscal balance and net banking system credit to the government. We also met the end-September target for fiscal balance, for which, with provisional data, we had cautiously asked for a waiver of nonobservance at the time of the last review. The net international reserves target was comfortably met. However, despite our prudent monetary policy, the end-December performance criterion on net domestic assets of the Central Bank was narrowly missed due to strong temporary liquidity demands in the last few days of the year in advance of the unusually long holiday period. Also, the indicative target on the stock of tax credits for end-December was missed. As outlined below, structural benchmarks were implemented largely as planned.

3. This Letter of Intent builds on these achievements, laying out an agenda for 2010 that supports the exit path from the crisis. Our macroeconomic policies will need to strike a balance between the risk of choking off economic recovery and containing macroeconomic pressures that may emerge. We will also continue efforts on structural reforms to increase tax revenue, develop a sound financial system, and build the foundations for sustained diversified economic growth and poverty reduction. We remain committed to implementing the measures contained in previous letters of intent.

\section{Recent Developments and Outlook for 2010}

4. Economic activity has stabilized, while inflation has increased. Domestic demand, mainly for non-durable goods, has held steady thanks to our stimulus package. Recovery is evident in some sectors, including the mining and metallurgy industries. Inflation has increased on the basis of strengthening international commodity prices, some lagged 
pass-through effects from the exchange rate depreciation observed in the first part of 2009, and initial signs of pressure in selected services.

5. We expect a mild recovery in 2010. Prospects for the world economy and the Russian economy in particular have improved moderately, providing support for remittances and the tradable sector. Financial sector intermediation is picking up, and will support growth and domestic demand. Changes in private consumption and investment, which were contributing to the negative GDP growth in 2009, should make a positive contribution in 2010, whilst public consumption is expected to continue to show positive growth.

6. The external position remains vulnerable, but we aim to reduce the current account deficit over time. Despite the contraction in domestic demand and real depreciation, the 2009 current account deficit diminished only moderately in dollar terms and stands close to 14 percent of GDP, strongly influenced by the effect of regional trends in exports and remittances. External imbalances are expected to persist in 2010, reflecting the weak recovery of our main trading partners and continued strong public investment, while our gross financing needs broadly remain as envisaged in the beginning of the program.

\section{Monetary, Exchange Rate and Financial Policies}

7. We are adjusting our monetary stance in line with inflation developments. Inflation has now fallen out of our target band, so consistent with our price stability objective, we increased our policy rate by 100 basis points since the beginning of the year. We have also decreased the amount of outstanding repos significantly, while tight liquidity conditions have created a moderate wedge between our policy and market rates. We will further gradually adjust the policy rate to become positive in real terms. In this setting, inflation will come down from highs in the first quarter, and we will continue pursuing policies to bring it within the target band in the near future.

8. We will continue to strengthen our monetary framework. In light of increased dollarization, we will pay more attention to monetary aggregates, including base money, and consider the effectiveness of current rules of monetary policy implementation and communication in consultation with the Fund, including if necessary on-site discussions, assistance or studies by IMF experts. We aim to strengthen the transmission mechanism by implementing several dedollarization measures. And to enhance the effectiveness of our policy rate, we will use more frequently our available instruments to offset government's lumpy spending, therefore reducing the volatility of short-term market rates. To deepen the secondary market, we will also introduce an overnight interbank market trading platform in NASDAQ-OMX. Lastly, we will outline an effective communications strategy to explain to the public the temporary nature of price developments behind the headline index.

9. We remain committed to the floating exchange rate regime. We have intervened in the foreign exchange market to smooth excessive volatility and counter speculative 
pressures to prevent large depreciations from threatening monetary and financial stability. We will continue to allow increased flexibility in exchange rate movements aiming at creating two-way risks in the market. In order to facilitate economic adjustments needed to maintain external stability, we will not intervene to resist fundamental trends in the exchange rate.

10. The health of the banking sector is improving, but we continue to closely monitor the situation. Banking sector balance sheets are improving steadily. Non-performing loans have been falling and profitability has turned positive since September. Lending activities have started recovering in recent months, fueled in part by our on-lending programs. We expect lending to continue to grow in 2010, although only at a moderate pace because of current and prospective prudential regulations. In the near term, dram lending is likely to be limited by high dollarization of deposits (as banks strive to balance their foreign currency position), but will still be supported by the continuation of the government's refinancing operations through the banking system. Capital and liquidity ratios remain strong and latest stress tests continue to show financial soundness.

11. We have taken concrete steps to limit vulnerabilities of the financial sector and we continue to improve our crisis preparedness and contingency planning. In April 2010, the limits on net open foreign exchange positions of $+/-7$ percent of capital will come into full effect. We also plan to strengthen prudential regulations to address currencyinduced credit risk to ensure that banks' capital buffer would be sufficient to deal with a deterioration in the FX loan portfolio. In particular, loan-loss provisioning requirements and risk weights in capital requirements for foreign currency loans will be increased (structural benchmark, June 2010). This year, we plan to formalize the Committee for Financial Stability (structural benchmark, September 2010), after we receive further assistance from Fund TA on contingency planning, specifically to set out modalities for policy makers to coordinate their policies and responses, including the division of responsibilities and information sharing among stakeholders (CBA, MOF, and DGF). We will also issue a prudential regulation requiring banks to prepare their contingency plans (structural benchmark, December 2010). Furthermore, we would welcome the opportunity to undergo a Stability FSAP Module to help diagnose and address remaining vulnerabilities.

12. Given these improvements, we plan to phase out the temporary crisis-related supporting measures this year. Specifically, the capital injection-matching subordinated debt facility and guarantee on interbank lending are no longer needed and will be discontinued to minimize risks to the CBA's balance sheet and potential conflict of interest.

\section{Fiscal Policy}

13. The fiscal deficit will be reduced in 2010, whilst social and capital spending will be maintained at an adequate level. We recognize that early withdrawal of fiscal stimulus could break the virtuous circle associated with an economic recovery. However, given positive signs in economic activity and debt sustainability concerns, we do not plan to increase the stimulus further. As such, the 2010 budget envisages broadly stable spending 
in nominal terms, while revenues will increase due to greater economic activity and improved tax administration. This will still imply a lowering in the deficit to around 6 percent of GDP, down from 7.5 percent of GDP in 2009. We intend to save any revenue over-performance above budgeted amounts. In the unlikely event that revenues fall below expectations, we will implement contingency measures to ensure that the deficit target is respected. In absolute terms, the deficit will continue to be significant, but financing is already secured through external support from donors, and we intend to issue t-bills to cover the remaining financing needs.

14. We remain firmly committed to medium-term fiscal sustainability. To this end, our fiscal consolidation program envisages a gradual reduction in the deficit. We will meet the requirements of our law that the deficit must be brought below 3 percent of the average last three years' GDP when debt levels surpass 50 percent of GDP. The mediumterm adjustment will rely on both revenue and expenditure measures, while ensuring sufficient social and capital spending. In order to strengthen our fiscal framework, we will submit to the government a medium term budget framework for 2011-13 laying out our revenue projections, assumptions, and risks, spending priorities, funding sources, debt dynamics, as well as specific measures to deal with transitory shocks and/or the materialization of contingent liabilities (structural benchmark, July 2010).

\section{Fiscal Structural Reforms}

15. The crisis did not hinder progress on our ambitious tax administration reforms. All VAT refund claims filed in 2009 have been processed within the statutory 90 -day processing deadline, with the exception of a few cases in which delays were temporary due to taxpayers' failure to provide necessary documentation. We will continue to process them within that timeframe during 2010. We have also made progress in implementing reforms in other areas, including (i) the introduction of mandatory e-filing of tax returns in 2009 for large taxpayers, which will be expanded over the course of 2010 to all other taxpayers; (ii) the development of a concept note on risk-based selection of taxpayers subject to audit, which was approved by the cabinet; and (iii) the improvement of analytical capacity of the tax agents. In addition, in close cooperation with CBA, we aim to start efforts at the SRC to enforce currency regulations.

16. Going forward, we remain committed to our revenue administration reforms to enhance the business environment and ensure a sustainable revenue base. The overall stock of tax credits was marginally reduced in 2009, although the indicative target for end-December 2009 was missed. Nonetheless, we remain strongly committed to addressing the systemic problems underlying tax credits, and to implement measures to ensure that unwarranted advance tax payments do not arise. Moreover, we will continue to focus on further strengthening VAT refund processing, including by implementing a fully functional risk-management approaches in VAT refund processing for which we will (i) submit legislation to parliament to allow only high risk VAT refunds to be subject to review (structural benchmark, March 2010), and (ii) adopt a government decree establishing a mechanism for implementing such a system (structural benchmark, December 2010 with actual implementation taking place by June 2011). To further strengthen the penalty regime, we will submit legislation to parliament allowing 
consolidation of VAT returns and refund claims in a single application, which will also contribute to streamlining the process. Fund TA is helping us in all these efforts, and we welcome the support provided by an IMF tax administration resident advisor who will commence his duties in March 2010.

17. Progress has been also made in tax policy to increase tax collection over the medium term. Specifically, and in line with our commitment to abolishing presumptive taxation for fuel and tobacco products, we have submitted legislation to parliament to bring these products within the regular VAT regime effective January 2011. Moreover, we will submit legislation to parliament to abolish the presumptive taxation regime for certain activities (structural benchmark, September 2010). Finally, we intend to review the selection criteria to optimize the amount of taxpayers in the large taxpayers unit.

18. We are committed to strengthening public financial management and our medium-term debt management capacity. We intend to move the accounts of the Project Implementation Units (PIUs) from commercial banks to treasury accounts. As such, we intend to strengthen our debt monitoring and planning capacity, in line with our objectives set at the time of the last review. Furthermore, we will adopt a time-bound action plan to develop and implement a comprehensive medium-term debt management strategy. Reflecting the adjustment of the current account and the projected rebound in growth, the external debt-to-GDP ratio is expected to remain sustainable despite the rapid rise in public debt in the last two years.

\section{Other Reforms}

19. We will continue our efforts to deepen structural reforms that will sustain economic recovery, enhance the productive capacity of the economy, and promote longterm economic growth. These reforms include substantial investments in transportation infrastructure and information technology. We continue to be committed to maintaining an open trade regime. We are carrying out a number of initiatives to improve Armenia's business environment, with a focus on improving the capacity of regulatory bodies and the ease of doing business. We also intend to continue our anti-corruption efforts, notably by addressing conflict of interest issues involving public officials. Finally, we are considering measures to increase competition and level the playing field, with a view to eliminating market domination in key sectors. We expect that structural reforms will result in considerable competitiveness gains over the medium term.

20. We remain committed to reducing poverty and protecting the poorest members of our society. To that effect, and in collaboration with the World Bank, we have developed a strategy to further strengthen the targeting of social safety nets. Going forward, we intend to identify an indicator that reflects spending efforts in this area, which will enable us to assess the effectiveness of our social policies in tackling poverty. 


\section{Conclusion}

21. We request the completion of the Third Review under the Stand-By Arrangement in light of the performance under the program and our continued commitment to strong policies. Given the changed outlook, we also request modification of the end-March performance criteria for net international reserves, net domestic assets of the CBA, net banking system credit to the government, and the program fiscal balance. On the latter, we request a change in its definition to ease monitoring. In addition, we wish to reintroduce the indicative target on reserve money ceiling starting March 2010. Finally, we request the establishment of performance criteria for end-June 2010, and a waiver for the end-December 2009 performance criterion on net domestic assets of the CBA, given that the deviation was minor and temporary. We expect to complete the fourth review on or after May 14, 2010, and the fifth review on or after August 15. We will maintain the close policy dialogue with the Fund and stand ready to take additional measures, as appropriate, to ensure the achievement of the government social and economic objectives under the Stand-By Agreement. We will continue to consult with the Fund on the adoption of measures, and in advance of revisions of the policies contained in the LOI, in accordance with the Fund's policies on such consultation. We will also provide the Fund with information it requests for monitoring progress during program implementation. The program's quantitative performance criteria and indicative targets for 2010 and structural benchmarks are set out in Tables 1 and 2.

22. As we enter the post-crisis period, we are considering the merits of shifting to a Fund facility more tailored to our medium term challenges. In particular, weaknesses in our balance of payments and a large structural reform agenda will remain, and we will be in close contact with Fund staff on the facility most appropriate to address these challenges.

23. We authorize the IMF to publish the Letter of Intent and its attachments as well as the accompanying staff report.

Very truly yours,

$/ \mathrm{s} /$

Tigran Sargsyan

Prime Minister Republic of Armenia

$/ \mathrm{s} /$

Tigran Davtyan

Minister of Finance

Republic of Armenia /s/

Artur Javadyan

Chairman of the Central Bank

Republic of Armenia 
Table 1. Armenia: Quantitative Targets, 2008-10 1/

(In billions of drams, at program exchange rates, unless otherwise specified)

\begin{tabular}{|c|c|c|c|c|c|c|c|c|c|c|c|c|c|c|c|}
\hline & \multirow{3}{*}{$\begin{array}{l}2008 \\
\text { Dec. }\end{array}$} & \multicolumn{9}{|c|}{2009} & \multicolumn{5}{|c|}{$20102 /$} \\
\hline & & \multicolumn{2}{|c|}{ Mar. } & \multicolumn{2}{|c|}{ Jun. } & \multicolumn{2}{|c|}{ Sep. } & \multicolumn{3}{|c|}{ Dec. } & \multicolumn{2}{|l|}{ Mar. } & \multirow{2}{*}{$\begin{array}{l}\text { Jun. } \\
\text { Prog. }\end{array}$} & \multirow{2}{*}{$\begin{array}{l}\text { Sep. } \\
\text { Prog. }\end{array}$} & \multirow{2}{*}{$\begin{array}{l}\text { Dec. } \\
\text { Prog. }\end{array}$} \\
\hline & & Adj. Prog. & Act. & Adj. Prog & Act. & Adj. Prog & Act. & $\begin{array}{c}\text { Country Report } \\
\text { No. } 09 / 316\end{array}$ & Adj. Prog & Prel. & $\begin{array}{c}\text { Country Report } \\
\text { No. } 09 / 316\end{array}$ & Prog. & & & \\
\hline \multicolumn{16}{|l|}{ Performance Criteria } \\
\hline Net official international reserves (floor, in millions of dollars) & $1,056.6$ & 455.9 & 654.1 & 990.7 & $1,089.7$ & 828.7 & $1,097.4$ & 976.8 & 989.8 & 1018.9 & 897.8 & 887.8 & 875.3 & 833.0 & 888.7 \\
\hline Net domestic assets of the CBA (ceiling) & 75.3 & 143.6 & 32.3 & -27.5 & -115.9 & -23.4 & -87.4 & -11.4 & -12.1 & -11.7 & 31.2 & 8.9 & 14.8 & 38.0 & 30.3 \\
\hline Net banking system credit to the government (ceiling) & -37.3 & -23.6 & -10.6 & -120.9 & -167.1 & -113.5 & -162.6 & -50.6 & & -125.3 & 4.2 & -91.6 & -93.2 & -76.8 & -89.6 \\
\hline Program fiscal balance (floor) 3/ & -68.2 & -29.9 & -36.2 & -123.4 & -91.2 & -212.3 & -205.9 & -342.4 & -385.8 & -354.8 & -89.0 & -59.7 & -92.5 & -121.3 & -148.6 \\
\hline External public debt arrears (continuous criterion) & $\cdot$ & 0 & 0 & 0 & 0 & 0 & 0 & 0 & & 0 & 0 & 0 & 0 & 0 & 0 \\
\hline \multicolumn{16}{|l|}{ Indicative Targets } \\
\hline Reserve money (ceiling) 4/ & 449.7 & 381.3 & 391.7 & $\ldots$ & $\ldots$ & $\ldots$ & $\ldots$ & $\ldots$ & $\ldots$ & $\ldots$ & $\ldots$ & 496.7 & 512.6 & 534.3 & 562.7 \\
\hline Stock of tax credits (ceiling) $5 /$ & 154.4 & 154.4 & 147.0 & 147.0 & 134.9 & 145.0 & 143.3 & 134.9 & & 152.8 & $\ldots$ & 148.0 & $\ldots$ & $\ldots$ & $\ldots$ \\
\hline \multicolumn{8}{|c|}{ Contracting or guaranteeing of new non-concessional debt (ceiling, in millions of dollars) 6/ } & 0 & & 0 & 195.0 & 195.0 & 225.0 & 300.0 & 325.0 \\
\hline
\end{tabular}

1/ All items as defined in the TMU. The figures in bold indicate when a target has not been met.

2/ Indicative targets for September and December.

3/ Below-the-line overall balance excluding net lending until 2009. Below-the-line overall balance excluding net lending and project financing from 2010.

4/ Reintroduced starting March 2010.

5/ Indicative target up to end-March 2010.

6/ For 2009, cumulative beginning the second half and therefore excludes the Russian loan contracted in June 2009 
Table 2. Armenia: Structural Benchmarks for the Third and Fourth Reviews

\begin{tabular}{|c|c|c|c|}
\hline Item & Measure & $\begin{array}{l}\text { Proposed Time } \\
\text { Frame } \\
\text { (End of Period) }\end{array}$ & Outcome \\
\hline & $\underline{\text { Tax administration }}$ & & \\
\hline 1 & Meet the statutory 90-day processing deadline for all VAT refund claims filed in 2009. & Continuous in 2009 & Met \\
\hline 2 & $\begin{array}{l}\text { As a necessary condition for implementing a fully functional risk-based approach to VAT } \\
\text { refund processing, submit legislation to parliament that allows only high-risk VAT refunds } \\
\text { to be subject to review. }\end{array}$ & March 2010 & \\
\hline \multirow[t]{2}{*}{3} & $\begin{array}{l}\text { Adopt a government decree establishing a mechanism for implementing a fully functional } \\
\text { risk management approaches in VAT refund processing. }\end{array}$ & December 2010 & \\
\hline & $\underline{\text { Tax and social policy }}$ & & \\
\hline 4 & $\begin{array}{l}\text { In close collaboration with the World Bank, develop a strategy to further strengthen the } \\
\text { targeting of social safety nets. }\end{array}$ & December 2009 & Met \\
\hline 5 & $\begin{array}{l}\text { Submit legislation to parliament to bring petroleum and tobacco products within the regular } \\
\text { tax regimes (excise tax, customs duties, profit tax, and VAT), effective January } 2011 \text {. }\end{array}$ & December 2009 & Met \\
\hline \multirow[t]{2}{*}{6} & $\begin{array}{l}\text { Submit legislation to parliament amending the Law on Presumptive Taxes to allow transfer } \\
\text { of certain types of activities identified in the Law on Presumptive Taxes to the general } \\
\text { taxation system. }\end{array}$ & September 2010 & \\
\hline & Fiscal sustainability & & \\
\hline \multirow[t]{2}{*}{7} & Submit a medium-term fiscal framework $(2011-13)$ to the government. & July 2010 & \\
\hline & Financial sector & & \\
\hline 8 & $\begin{array}{l}\text { Issue prudential regulations to specifically address currency-induced credit risk, including } \\
\text { increased loan-loss provisioning requirements and higher risk weights in capital } \\
\text { requirements for foreign currency loans. }\end{array}$ & June 2010 & \\
\hline 9 & Formalize the Committee for Financial Stability in an MOU. & September 2010 & \\
\hline 10 & Issue prudential regulation requiring banks to prepare their contingency plans. & December 2010 & \\
\hline
\end{tabular}




\section{Attachment II. Armenia: Technical Memorandum of Understanding}

1. This memorandum sets out the understandings between the Armenian authorities and the IMF staff regarding the definition of performance criteria and indicative targets, their adjusters, and data reporting requirements for the Stand-by Arrangement. This memorandum updates and replaces the TMU dated October 14, 2009. It sets out the definitions for quantitative performance criteria, indicative targets, benchmarks, adjusters, as well as the reporting modalities referred to in the Letter of Intent dated March 10, 2010, under which Armenia's performance under the program supported by the Stand-by Arrangement (SBA) will be assessed.

2. For program monitoring purposes, all foreign currency-related assets, liabilities, and flows in the monetary accounts will be evaluated at program exchange rates. The program exchange rate of the Armenian dram to the U.S. dollar is set at dram 385 per one U.S. dollar. The cross-rates for other foreign currencies are provided in Table 1.

3. For purpose of monitoring, the central government is defined as general government less local government and less off-budget funds.

\section{Quantitative Targets}

4. The program sets performance criteria and indicative targets for defined test dates (see Table 1 in the Letter of Intent dated March 10, 2010). The program sets the following performance criteria:

- Floor on the net official international reserves (NIR) of the Central Bank of Armenia (CBA);

- Ceiling on the net domestic assets (NDA) of the CBA;

- Ceiling on the net banking system credit to the general government;

- Ceiling on external public debt arrears (continuous);

- Floor on the program fiscal balance;

The program sets the following indicative targets:

- Ceiling on reserve money;

- Ceiling on tax credits stock;

- Ceiling on contracting or guaranteeing of new nonconcessional external debt by the public sector.

5. The net official international reserves (stock) will be calculated as the difference between total gross official international reserves (excluding reserve money denominated in foreign currencies) and gross official reserve liabilities. Total gross official international reserves are defined as the CBA's holdings of monetary gold (excluding amounts pledged as collateral or in swaps), holdings of Special Drawing Rights (SDRs), including the August 28, 2009 General allocation and the September 9, 2009 Special allocation, any reserve position in the IMF, and holdings of convertible currencies in cash or in nonresident financial institutions (deposits, 
securities, or other financial instruments). Gross reserves held in the form of securities and other financial instruments are marked to market. Gross reserves are reported excluding the balance on the government's Special Privatization Account (SPA) and exclude capital subscriptions in foreign financial institutions and illiquid foreign assets. Official reserve liabilities shall be defined as the total outstanding liabilities of the government and the CBA to the IMF and convertible currency liabilities of the CBA to nonresidents with an original maturity of up to and including one year. NIR is monitored in U.S. dollars, and, for program monitoring purposes, assets and liabilities in currencies other than the U.S. dollar shall be converted into dollar-equivalent values using the exchange rates as specified in Table 1.

6. The net domestic assets are defined as reserve money minus NIR, minus reserve money denominated in foreign currencies, plus medium and long-term liabilities (i.e. liabilities with a maturity of one year or more) of the CBA, plus the balance of outstanding Fund purchases credited to the government account at the CBA. NDA is composed of net CBA credit to the general government; outstanding credit to domestic banks by the CBA (including overdrafts) minus liabilities not included in reserve money, and other items net. Reserve money is defined as the sum of currency issued, required and excess reserves, and current and time deposit accounts of certain resident agents. Liquidity absorbing transactions under reverse repurchase agreements, the CBA's deposit facility, foreign currency swaps, and securities issued by the CBA are excluded from the reserve money definition.

7. The banking system credit to the general government is defined as the sum of net credit from the CBA and net credit from commercial banks to the general government.

- The stock of net credit from the CBA to the general government includes the CBA's holdings of treasury bills and treasury bonds less all types of government deposits with the CBA (including the deposits in the Treasury Single Account, the Lincy foundation, and balances of proceeds from the sale of humanitarian assistance). Treasury bonds are valued at the purchase price and excluding accrued interest, and treasury bills are valued at the purchase price plus the implicit accrued interest.

- Net credit from commercial banks to the general government includes: (1) gross commercial bank credit to the general government less general government deposits with commercial banks; and (2) bank holdings of treasury bonds (valued at the purchase price and excluding accrued interest) and treasury bills (valued at the purchase price plus the implicit accrued interest).

8. External public debt arrears are defined as all unpaid debt-service obligations (i.e., payments of principal and interest) arising in respect of public sector loans contracted or 
guaranteed, including unpaid penalties or interest charges associated with these obligations that are overdue beyond 30 days after the due date. ${ }^{1}$ The ceiling on external payment arrears is set at zero.

9. The program fiscal balance is cumulative from the beginning of the fiscal year and is measured from the financing side as the negative of the sum of net domestic banking system credit to the central government, net domestic nonbank financing, and net external financing to the central government (excluding net project financing). Should a general subsidy be introduced offbudget, the overall balance will be measured including the subsidy as part of government spending.

- Net banking system credit to the central government equals the change during the period of net credit to the central government. Central government is defined as general government less local government and less off-budget funds.

- Net nonbank financing equals the sum of: (1) the change during the period of outstanding treasury bills and bonds to nonbanks (including accrued interest for treasury bills and excluding accrued interest for treasury bonds) $;^{2}(2)$ any other disbursement or transaction that increases nonbanks' claims on the central government plus withdrawals from the special privatization account or the treasury sub-account containing privatization proceeds in drams, less amortization paid by the central government to private resident nonbank agents.

- Net external financing equals total debt-increasing disbursements from non-residents to the central government (including Fund net purchases credited directly to the government accounts at the CBA) less total amortization from the central government to non-residents. All foreign currency-denominated transactions are recorded in drams using the prevailing exchange rate at the time of the transaction.

10. Those project implementation units, that carry out projects financed by the US-based Lincy Foundation, or other budget-related project implementation units maintain accounts at the CBA. The grants are recorded in the fiscal accounts as external grants on the revenue side and as foreignfinanced capital expenditure on the expenditure side. In addition, any loans to finance investments and that are intermediated through the banking system are recorded in the financial accounts as a financing item below the line and are thus excluded from net lending.

11. Foreign currency proceeds from selling enterprises are deposited into the Special Privatization Account (SPA). The account is held at the CBA and the proceeds are invested abroad together with the CBA's international reserves. These proceeds are included in the definition of the

\footnotetext{
${ }^{1}$ The public sector is defined following the Government Financial Statistics Manual(GFS 2001) and System of National Accounts (1993 SNA). It includes the general government and nonfinancial public enterprises.

${ }^{2}$ Domestic nonbank holdings of treasury bills and treasury bonds are defined as total outstanding treasury bills and bonds less holdings by the banking system and the State Fund for Social Insurance.
} 
monetary accounts of the CBA as part of net foreign assets with a counter entry in other items net. Any budgeted withdrawal from the SPA will be accounted for as privatization proceeds used to finance the budget and will be recorded below the line. Any unanticipated withdrawal from the SPA will be recorded below the line as privatization receipts; these withdrawals, however, will be replenished during the same fiscal year. Domestic currency proceeds from selling enterprises to residents are deposited in a sub-account of the treasury single account.

12. The program sets a ceiling on reserve money. Reserve money is defined as the sum of currency issued, required and excess reserves, and current and time deposit accounts of certain resident agents. The ceiling will be considered as met if the outcome is within AMD 5 billion of the indicative target set in Table 1 attached to the Letter of Intent dated March 10, 2010.

13. The stock of tax credits (indicative target) is defined as the sum of outstanding accumulated credit by the State Revenue Committee (SRC) of all types of tax revenues (VAT, profit tax, excises, income tax, presumptive payments, and others) resulting from advanced tax payments to be offset against future tax liabilities.

14. The program sets a ceiling on contracting or guaranteeing of new nonconcessional external debt by the public sector. The definition of debt, for the purposes of the program, is set out in Executive Board Decision No. 12274, Point 9, as revised on August 24, 2000. For program purposes, nonconcessional external loans are defined as loans from lenders other than the IMF with a grant element of less than 35 percent of the value of the loan. The grant element is to be calculated as follows: the grant element of a debt is the difference between the net present value (NPV) of debt and its nominal value, expressed as a percentage of the nominal value of the debt. The NPV of debt at the time of its contracting is calculated by discounting the future stream of payments of debt service due on this debt. The discount rates used for this purpose are the currency specific commercial interest reference rates (CIRRs), published by the Organization for Economic Cooperation Development (OECD). For debt with a maturity of at least 15 years, the ten-yearaverage CIRR will be used to calculate the NPV of debt and, hence, its grant element. For debt with a maturity of less than 15 years, the six month average CIRR will be used. For both the tenyear and six-month averages, the same margins for differing repayment periods as those used by the OECD would continue to be added ( 0.75 percent for repayment periods of less than 15 years, 1 percent for 15 to 19 years, 1.15 percent for 20 to 29 years, and 1.25 percent for 30 years or more). Loans provided by a private entity will not be considered concessional unless accompanied by a grant or grant element provided by a foreign official entity, such as both components constitute an integrated financing package with a combined grant element equal to at least 35 percent. Previously contracted nonconcessional external debt that has been rescheduled will be excluded from the definition of "new debt" for the purposes of this performance criterion.

\section{Adjusters}

15. The quantitative performance criteria and indicative targets under the program are subject to the following adjusters, calculated, where relevant, using program exchange rates: 
- Changes in reserve requirements: The ceiling on the NDA of the CBA will be adjusted downward (upward) by the amount of banks' reserves freed (seized) by any reduction (increase) of the reserve requirement ratio on both domestic currency and foreign currency deposits relative to the baseline assumption as per the following formula: $\Delta \mathrm{NDA}=\Delta \mathrm{rB}$, where $\mathrm{B}$ denotes the level of the deposits subject to reserve requirements in the initial definition and $\Delta \mathrm{r}$ is the change in the reserve requirement ratio.

- KfW and World Bank loan disbursements: the ceiling on the NDA of the CBA will be adjusted upward (downward) by the full amount of any excess (shortfall) of disbursements from the KfW and World Bank loans directed at SME financing compared to programmed amounts (Table 2). The floor on NIR will be adjusted upward (downward) by the cumulative amount of any excess (shortfall) of these disbursements compared to program amounts.

- External financing to the public sector, defined as disbursements of loans from bilateral and multilateral donors for budget support, and the $\$ 500$ million Russian loan disbursed in 2009 (including Fund purchases credited directly to the government accounts at the CBA), with the exception of the KfW and World Bank disbursements mentioned above:

- The floor on NIR will be adjusted upward (downward) by the cumulative amount of any excess (shortfall) of external financing in the form of budget support (excluding Fund disbursements to the government) compared to program amounts (Table 3).

- The ceiling on NDA will be adjusted upward by the amount of any shortfall of external financing in the form of budget support compared to program amounts.

- The ceiling on net banking sector credit to government will be adjusted upward by the cumulative amount of any shortfall of total external budget support financing compared to programmed amounts (Table 3 ).

- The floor on the program fiscal balance on a cash basis will be adjusted downward by the cumulative amount of any excess of total external budget support financing compared to programmed amounts (Table 3). The floor on the program fiscal balance will be adjusted downward by the amount of any shortfall in receipt of grants under the European Union budget support program.

- Recapitalization of the CBA: the ceiling on net credit of the banking system to the government will be adjusted upward by the full amount of the recapitalization of the CBA. 


\section{Data Reporting}

The government will provide the IMF the information specified in the following table.

\begin{tabular}{|c|c|c|c|c|}
\hline $\begin{array}{c}\text { Reporting } \\
\text { Agency }\end{array}$ & Type of Data & Description of Data & Frequency & Timing \\
\hline \multirow[t]{12}{*}{$\mathrm{CBA}^{3}$} & CBA balance sheet & Summary & Daily & $\begin{array}{l}\text { The following } \\
\text { working day }\end{array}$ \\
\hline & CBA balance sheet & $\begin{array}{l}\text { Summary at program exchange rates; } \\
\text { and by chart of accounts at actual } \\
\text { official exchange rates }\end{array}$ & Monthly & $\begin{array}{l}\text { Within seven days } \\
\text { of the end of each } \\
\text { month }\end{array}$ \\
\hline & Monetary survey & $\begin{array}{l}\text { Summary banking system balance sheet } \\
\text { for the central bank at both program } \\
\text { exchange rates and by chart of accounts } \\
\text { at actual official exchange rates; the } \\
\text { consolidated balance sheet of } \\
\text { commercial banks by chart of accounts } \\
\text { at actual official exchange rates }\end{array}$ & Monthly & $\begin{array}{l}\text { Within } 25 \text { days of } \\
\text { the end of each } \\
\text { month }\end{array}$ \\
\hline & International reserves & $\begin{array}{l}\text { By chart of accounts; at (i) program } \\
\text { exchange rates; and (ii) at actual } \\
\text { official exchange rates }\end{array}$ & Daily & $\begin{array}{l}\text { The following } \\
\text { working day }\end{array}$ \\
\hline & $\begin{array}{l}\text { Foreign exchange } \\
\text { market }\end{array}$ & $\begin{array}{l}\text { Official exchange rates (buying and } \\
\text { selling); daily trade volume, and } \\
\text { weighted average exchange rate of the } \\
\text { interbank, intrabank and Nasdaq-OMX }\end{array}$ & Daily & Within 1 day \\
\hline & $\begin{array}{l}\text { Foreign exchange } \\
\text { market }\end{array}$ & $\begin{array}{l}\text { CBA foreign exchange operations, } \\
\text { (exchange rate, volume, counterpart) }\end{array}$ & Daily & Within 1 day \\
\hline & $\begin{array}{l}\text { Foreign exchange } \\
\text { market }\end{array}$ & Exchange rate (buying and selling) & Daily & Within 1 day \\
\hline & Interest rates & Refinance rate & $\begin{array}{l}\text { At least } \\
\text { monthly }\end{array}$ & $\begin{array}{l}\text { Within } 1 \text { days of } \\
\text { the CBA Board } \\
\text { decision }\end{array}$ \\
\hline & $\begin{array}{l}\text { Interbank money } \\
\text { market }\end{array}$ & $\begin{array}{l}\text { Daily interbank repo volume and } \\
\text { interest rate and number of trades }\end{array}$ & Daily & Within 1 day \\
\hline & CBA operations & $\begin{array}{l}\text { Repo (reverse repo) operations, open } \\
\text { market operations, Lombard credits, } \\
\text { deposit facility, and foreign exchange } \\
\text { swaps (volumes, maturity, yields, } \\
\text { exchange rates) }\end{array}$ & Daily & Within 1 day \\
\hline & Bank liquidity & $\begin{array}{l}\text { Reserves and excess reserves, by } \\
\text { currency }\end{array}$ & Monthly & $\begin{array}{l}\text { Within } 15 \text { days of } \\
\text { the end of each } \\
\text { reference period }\end{array}$ \\
\hline & Interest rates and flows & By currency and maturity & Weekly & Last working day \\
\hline
\end{tabular}

${ }^{3}$ As defined in CBA resolution No. 201 (December 6, 1999). 


\begin{tabular}{|c|c|c|c|c|}
\hline & $\begin{array}{l}\text { of the funds attracted } \\
\text { and allocated by } \\
\text { commercial banks }\end{array}$ & & & of the week \\
\hline & $\begin{array}{l}\text { T-bill and coupon bond } \\
\text { financing, CBA } \\
\text { securities }\end{array}$ & $\begin{array}{l}\text { Auction data: date, original and } \\
\text { remaining maturities, issuance volume, } \\
\text { allocation, average yield and coupon } \\
\text { yield (if available) }\end{array}$ & Weekly & $\begin{array}{l}\text { Last working day } \\
\text { of the week }\end{array}$ \\
\hline & Banking data & $\begin{array}{l}\text { Sectoral distribution of loans and } \\
\text { deposits; dollarization of loans and } \\
\text { deposits; loan maturities; interbank } \\
\text { rate, by volume and maturity; T-bill } \\
\text { rate, bond yield; deposit and lending } \\
\text { rates, by maturity; monthly weighted } \\
\text { average interest rate on government } \\
\text { bonds }\end{array}$ & Monthly & $\begin{array}{l}\text { Within } 25 \text { days of } \\
\text { the end of each } \\
\text { month }\end{array}$ \\
\hline & Banking indicators & $\begin{array}{l}\text { Capital adequacy; asset composition } \\
\text { and quality; profitability; liquidity; } \\
\text { open FX positions; and compliance } \\
\text { with prudential norms }\end{array}$ & Monthly & $\begin{array}{l}\text { Within } 30 \text { days of } \\
\text { the end of each } \\
\text { month }\end{array}$ \\
\hline & $\begin{array}{l}\text { Banking sector stress } \\
\text { tests }\end{array}$ & $\begin{array}{l}\text { Results of stress tests on exchange rate, } \\
\text { liquidity, and credit risk }\end{array}$ & Monthly & $\begin{array}{l}\text { Within } 30 \text { days of } \\
\text { the end of each } \\
\text { month }\end{array}$ \\
\hline & CPI & Index of core inflation & Monthly & $\begin{array}{l}\text { Within } 21 \text { days of } \\
\text { the end of each } \\
\text { month }\end{array}$ \\
\hline & Transfers & $\begin{array}{l}\text { Non-commercial transfers of } \\
\text { individuals }\end{array}$ & Monthly & $\begin{array}{l}\text { Within } 30 \text { of the } \\
\text { end of each month }\end{array}$ \\
\hline & Other monetary data & IFS format & Monthly & $\begin{array}{l}\text { Within } 45 \text { days of } \\
\text { the end of each } \\
\text { month }\end{array}$ \\
\hline $\begin{array}{l}\text { Ministry of } \\
\text { Finance }\end{array}$ & $\begin{array}{l}\text { T-bill and coupon bond } \\
\text { financing }\end{array}$ & $\begin{array}{l}\text { By holders, i.e., CBA, resident banks, } \\
\text { resident nonbanks, and nonresidents }\end{array}$ & Monthly & $\begin{array}{l}\text { Within } 7 \text { days of } \\
\text { each month }\end{array}$ \\
\hline$(\mathrm{MOF})$ & External debt & $\begin{array}{l}\text { Disbursements and stock of outstanding } \\
\text { short-term and contracting or } \\
\text { guaranteeing and outstanding stock of } \\
\text { medium-and long-term external debt of } \\
\text { the government, the CBA, and state- } \\
\text { owned companies (by company); any } \\
\text { stock of arrears on external debt service } \\
\text { and outstanding stock of government } \\
\text { guarantees and external arrears }\end{array}$ & Monthly & $\begin{array}{l}\text { Within } 21 \text { days of } \\
\text { the end of each } \\
\text { month . } \\
\text { For project } \\
\text { implementation } \\
\text { units, within } 21 \\
\text { days of the end of } \\
\text { each month } \\
\text { (preliminary data) } \\
\text { and within } 45 \text { days } \\
\text { of the end of each } \\
\text { month (final data) }\end{array}$ \\
\hline & Revenue collection & $\begin{array}{l}\text { Total revenue collected separately by } \\
\text { the tax administration and customs } \\
\text { administration, including revenue by } \\
\text { individual tax, and social contributions }\end{array}$ & Monthly & $\begin{array}{l}\text { Within } 7 \text { days of } \\
\text { the end of each } \\
\text { month }\end{array}$ \\
\hline & $\begin{array}{l}\text { Domestic expenditure } \\
\text { arrears }\end{array}$ & $\begin{array}{l}\text { All unpaid claims outstanding at the } \\
\text { end of the month which includes } \\
\text { wages, social contributions (including }\end{array}$ & Monthly & $\begin{array}{l}\text { Within } 45 \text { days of } \\
\text { the end of each } \\
\text { month for }\end{array}$ \\
\hline
\end{tabular}




\begin{tabular}{|c|c|c|c|c|}
\hline & & $\begin{array}{l}\text { for pensions), family allowances, and } \\
\text { amortization and domestic interest } \\
\text { payments }\end{array}$ & & government arrears \\
\hline & Privatization receipts & $\begin{array}{l}\text { Balance on the SPA; gross inflows into } \\
\text { and outflows from the SPA during the } \\
\text { month, specifying the nature of each } \\
\text { transaction }\end{array}$ & Monthly & $\begin{array}{l}\text { Within } 7 \text { days of } \\
\text { the end of each } \\
\text { month }\end{array}$ \\
\hline & $\begin{array}{l}\text { Treasury single account } \\
\text { (TSA) }\end{array}$ & $\begin{array}{l}\text { Detailed breakdown of central treasury } \\
\text { account, including deposits at the } \\
\text { central treasury, community budgets, } \\
\text { off budget account, monetization } \\
\text { account, state budget account and the } \\
\text { Republic correspondent account- } \\
\text { flows during the month and end of } \\
\text { month stocks. }\end{array}$ & Monthly & $\begin{array}{l}\text { Within } 7 \text { days of } \\
\text { the end of each } \\
\text { month }\end{array}$ \\
\hline & $\begin{array}{l}\text { Consolidated central } \\
\text { government }\end{array}$ & State budget & Monthly & $\begin{array}{l}\text { Within } 30 \text { days of } \\
\text { the end of each } \\
\text { month }\end{array}$ \\
\hline & $\begin{array}{l}\text { Consolidated general } \\
\text { government }\end{array}$ & $\begin{array}{l}\text { Central and local governments, and } \\
\text { Non-Commercial Enterprises that } \\
\text { belong within the general government } \\
\text { (NCEs) }\end{array}$ & Quarterly & $\begin{array}{l}\text { Within } 60 \text { days of } \\
\text { the end of each } \\
\text { quarter }\end{array}$ \\
\hline & $\begin{array}{l}\text { Consolidated general } \\
\text { government }\end{array}$ & $\begin{array}{l}\text { Central and local governments, and } \\
\text { NCEs that belong within the general } \\
\text { government }\end{array}$ & Annual & $\begin{array}{l}\text { Within } 180 \text { days of } \\
\text { the end of each } \\
\text { year }\end{array}$ \\
\hline & Budget execution & $\begin{array}{l}\text { All cash receipts, cash expenditures, } \\
\text { including domestic and external debt- } \\
\text { service payments, external and } \\
\text { domestic borrowing operations, and } \\
\text { inflow of grants to the central } \\
\text { government; expenditure data will be } \\
\text { provided according to both economic } \\
\text { and functional classifications, } \\
\text { consistent with the GFSM2001 } \\
\text { methodology }\end{array}$ & Monthly & $\begin{array}{l}\text { Within one month } \\
\text { following the end } \\
\text { of each quarter. }\end{array}$ \\
\hline \multirow[t]{4}{*}{ NSS } & \multirow[t]{3}{*}{ Balance of payments } & Detailed export and import data & Monthly & $\begin{array}{l}\text { Within } 28 \text { days of } \\
\text { the end of each } \\
\text { month }\end{array}$ \\
\hline & & Detailed export and import data & Quarterly & $\begin{array}{l}\text { Within } 45 \text { days of } \\
\text { the end of each } \\
\text { quarter }\end{array}$ \\
\hline & & Detailed balance of payments data & quarterly & $\begin{array}{l}\text { Within } 60 \text { days of } \\
\text { the end of each } \\
\text { quarter }\end{array}$ \\
\hline & CPI & By category & Monthly & $\begin{array}{l}\text { Within } 5 \text { days of } \\
\text { the end of each } \\
\text { month }\end{array}$ \\
\hline
\end{tabular}




\begin{tabular}{|c|c|c|c|c|}
\hline \multirow[t]{6}{*}{$\begin{array}{l}\text { State } \\
\text { Revenue } \\
\text { Committee }\end{array}$} & \multirow[t]{2}{*}{ Tax arrears } & By type of tax & Monthly & $\begin{array}{l}\text { Within } 30 \text { days of } \\
\text { the end of each } \\
\text { quarter (monthly } \\
\text { data provided on a } \\
\text { quarterly basis) }\end{array}$ \\
\hline & & $\begin{array}{l}\text { For or the } 30 \text { largest debtors and for all } \\
\text { major companies in the energy, water, } \\
\text { and irrigation sectors }\end{array}$ & Quarterly & $\begin{array}{l}\text { Within } 30 \text { days of } \\
\text { the end of each } \\
\text { quarter }\end{array}$ \\
\hline & Tax credits & $\begin{array}{l}\text { Detailed data, by type of tax, of } \\
\text { outstanding tax credits for all types of } \\
\text { tax revenues }\end{array}$ & Monthly & $\begin{array}{l}\text { Within } 45 \text { days of } \\
\text { the end of each } \\
\text { month (monthly } \\
\text { data provided on a } \\
\text { quarterly basis) }\end{array}$ \\
\hline & $\begin{array}{l}\text { VAT refund claims in } \\
\text { arrears }\end{array}$ & $\begin{array}{l}\text { Detailed data on VAT refunds in } \\
\text { arrears which include all outstanding } \\
\text { VAT refunds that have not been } \\
\text { accepted (and refunded), or offset (in } \\
\text { full or in part), or rejected (in full or in } \\
\text { part) after the } 90 \text { day statutory } \\
\text { processing period. Number of refund } \\
\text { applications processed per month. }\end{array}$ & Monthly & $\begin{array}{l}\text { Within } 45 \text { days of } \\
\text { the end of each } \\
\text { month (monthly } \\
\text { data provided on a } \\
\text { quarterly basis) }\end{array}$ \\
\hline & Large taxpayers & $\begin{array}{l}\text { Data on the number of taxpayers and } \\
\text { amount of taxes managed by the large } \\
\text { tax inspectorate }\end{array}$ & Monthly & $\begin{array}{l}\text { Within } 45 \text { days } \\
\text { after the end of } \\
\text { each month }\end{array}$ \\
\hline & Import data & $\begin{array}{l}\text { 1. Total value of recorded imports, } \\
\text { breaking out raw diamond imports; } \\
\text { 2. Total value of non-duty free } \\
\text { recorded imports; } \\
\text { 3. Number of total transactions } \\
\text { involving recorded imports; } \\
\text { 4. Number of total transactions } \\
\text { involving non-duty free recorded } \\
\text { imports } \\
\text { 5. Value of recorded imports where } \\
\text { customs value was assessed using } \\
\text { transaction prices, breaking out raw } \\
\text { diamond imports; } \\
\text { 6. Value of non-duty free recorded } \\
\text { imports where customs value was } \\
\text { assessed using transaction prices; } \\
\text { 7. Number of transactions involving } \\
\text { recorded imports where customs value } \\
\text { was assessed using transaction prices; } \\
\text { 8. Number of transactions involving } \\
\text { non duty free recorded imports where } \\
\text { customs value was assessed using } \\
\text { transaction prices }\end{array}$ & Quarterly & $\begin{array}{l}\text { Within } 30 \text { days of } \\
\text { the end of each } \\
\text { quarter }\end{array}$ \\
\hline
\end{tabular}


Table 1. Armenia: (Program) Exchange Rates of the CBA (As of December 31, 2008 in U.S. dollars per currency rates)

\begin{tabular}{lcc}
\hline Country & $\begin{array}{c}\text { Drams } \\
\text { Per } \\
\text { Currency }\end{array}$ & $\begin{array}{c}\text { Dollars } \\
\text { Per } \\
\text { Currency }\end{array}$ \\
\hline Australian dollar & 266.57 & 0.6924 \\
Canadian dollar & 313.39 & 0.8140 \\
Swiss franc & 365.58 & 0.9496 \\
Danish krone & 73.26 & 0.1903 \\
Euro & 546.00 & 1.4182 \\
Pound sterling & 558.68 & 1.4511 \\
Japanese yen & 4.27 & 0.0111 \\
Norwegian krone & 55.20 & 0.1434 \\
Russian ruble & 13.13 & 0.0341 \\
Swedish krone & 18.21 & 0.0473 \\
SDR & 593.00 & 1.5403 \\
\hline
\end{tabular}

Table 2. Armenia: KfW and IBRD SME Loan Disbursments, 2009-10 1/ (In millions of U.S. dollars)

\begin{tabular}{|c|c|c|c|c|c|c|c|c|c|c|c|}
\hline \multicolumn{2}{|c|}{ Mar-09 } & \multicolumn{2}{|c|}{ Jun-09 } & \multicolumn{2}{|c|}{ Sep-09 } & \multicolumn{2}{|c|}{ Dec-09 } & Mar-10 & Jun-10 & Sep-10 & Dec-10 \\
\hline $\begin{array}{r}\text { Prog. } \\
24\end{array}$ & $\begin{array}{r}\text { Actual } \\
55\end{array}$ & $\begin{array}{r}\text { Prog. } \\
24\end{array}$ & $\begin{array}{r}\text { Actual } \\
319\end{array}$ & $\begin{array}{r}\text { Prog. } \\
336\end{array}$ & $\begin{array}{r}\text { Actual } \\
338\end{array}$ & $\begin{array}{r}\text { Prog. } \\
356\end{array}$ & $\begin{array}{r}\text { Actual } \\
338\end{array}$ & Prog. & $\begin{array}{r}\text { Prog. } \\
4.0\end{array}$ & Prog. & $\begin{array}{r}\text { Prog. } \\
329\end{array}$ \\
\hline
\end{tabular}

$1 /$ Cumulative from the end of the previous year.

Table 3. Armenia: External Financing to the Public Sector, 2009-10 (program) 1/

(In billions of drams)

\begin{tabular}{|c|c|c|c|c|c|c|c|c|c|c|c|c|}
\hline & \multicolumn{2}{|c|}{ Mar-09 } & \multicolumn{2}{|c|}{ Jun-09 } & \multicolumn{2}{|c|}{ Sep-09 } & \multicolumn{2}{|c|}{ Dec-09 } & \multirow{2}{*}{$\begin{array}{r}\text { Mar-10 } \\
\text { Prog. }\end{array}$} & \multirow{2}{*}{$\begin{array}{r}\text { Jun-10 } \\
\text { Prog. }\end{array}$} & \multirow{2}{*}{$\begin{array}{r}\text { Sep-10 } \\
\text { Prog. }\end{array}$} & \multirow{2}{*}{$\frac{\text { Dec-10 }}{\text { Prog. }}$} \\
\hline & Prog. & Actual & Prog. & Actual & Prog. & Actual & Prog. & Actual & & & & \\
\hline Project financing & 14.7 & 12.2 & 50.8 & 33.0 & 81.2 & 67.5 & 62.7 & 100.4 & 19.7 & 58.6 & 79.2 & 117.0 \\
\hline Budget financing & 3.1 & - & 78.9 & - & 97.3 & 60.9 & 111.3 & 117.0 & 14.4 & 47.7 & 62.1 & 103.0 \\
\hline Russia & - & - & 192.5 & 192.5 & 192.5 & 192.5 & 192.5 & 192.5 & - & - & - & - \\
\hline Total & 17.8 & 12.2 & 322.3 & 225.5 & 371.1 & 320.8 & 366.5 & 409.9 & 34.1 & 106.3 & 141.2 & 220.1 \\
\hline
\end{tabular}

$1 /$ Cumulative from the end of the previous year, excluding grants. 


\section{Guidelines on the Indicative Benchmark with Respect to Foreign Debt}

Excerpt from Executive Board Decision No. 12274, as revised on August 24, 2000.

(a) For the purpose of this guideline, the term "debt" will be understood to mean a current, i.e., not contingent, liability, created under a contractual arrangement through the provision of value in the form of assets (including currency) or services, and which requires the obligor to make one or more payments in the form of assets (including currency) or services, at some future point(s) in time; these payments will discharge the principal and/or interest liabilities incurred under the contract. Debts can take a number of forms, the primary ones being as follows:

(i) loans, that is, advances of money to obligor by the lender made on the basis of an undertaking that the obligor will repay the funds in the future (including deposits, bonds, debentures, commercial loans, and buyers' credits) and temporary exchanges of assets that are equivalent to fully collateralized loans under which the obligor is required to repay the funds, and usually pay interest, by repurchasing the collateral from the buyer in the future (such as repurchase agreements and official swap arrangements);

(ii) suppliers' credits, that is, contracts where the supplier permits the obligor to defer payments until some time after the date on which the goods are delivered or services are provided; and

(iii) leases, that is, arrangements under which property is provided which the lessee has the right to use for one or more specified period(s) of time that are usually shorter than the total expected service life of the property, while the lessor retains the title to the property. For the purpose of the guideline, the debt is the present value (at the inception of the lease) of all lease payments expected to be made during the period of the agreement excluding those payments that cover the operation, repair or maintenance of the property.

(b) Under the definition of debt set out in point 9 (a) above, arrears, penalties, and judicially awarded damages arising from the failure to make payment under a contractual obligation that constitutes debt are debt. Failure to make payment on an obligation that is not considered debt under this definition (for example, payment on delivery) will not give rise to debt. 


\title{
INTERNATIONAL MONETARY FUND
}

\author{
REPUBLIC OF ARMENIA \\ Third Review under the Stand-By Arrangement, \\ Request for Waiver of Nonobservance of Performance Criterion, and \\ Modification of Performance Criteria \\ Informational Annex \\ Prepared by the Middle East and Central Asia Department
}

March 11, 2010

Contents

Page

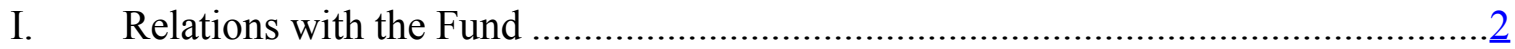

II. World Bank and IMF Collaboration - JMAP Implementation.................................. 6

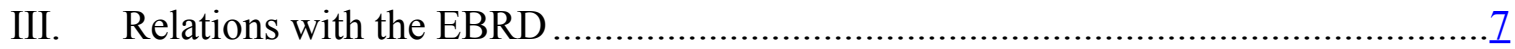

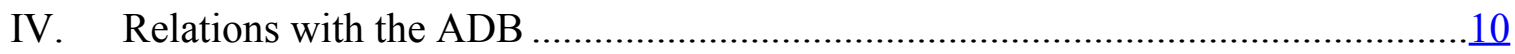

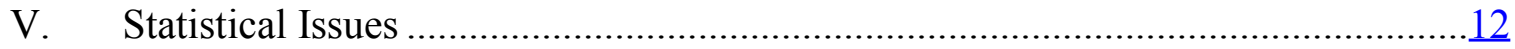


Annex I. Armenia: Relations with the Fund

(As of February 28, 2010)

I. Membership Status: Joined 05/28/1992; Article VIII

II. General Resources Account:

Quota

SDR Million

92.00

393.94

0.00

Reserve Tranche Position

III. SDR Department:

Net cumulative allocation

Holdings

IV. Outstanding Purchases and Loans:

Stand-by Arrangements

ECF arrangements
SDR Million

87.99

78.43

SDR Million

301.94

72.31
Percent of Quota

100.00

428.20

0.00

Percent of Allocation 100.00

89.13

Percent of Quota

328.20

78.60

V. Latest Financial Arrangements:

\begin{tabular}{|c|c|c|c|c|}
\hline Type & $\frac{\text { Approval }}{\underline{\text { Date }}}$ & $\frac{\text { Expiration }}{\underline{\text { Date }}}$ & $\begin{array}{l}\text { Amount Approved } \\
\text { (SDR Million) }\end{array}$ & $\begin{array}{l}\text { Amount Drawn } \\
\text { (SDR Million) }\end{array}$ \\
\hline Stand-By & 03/6/09 & $07 / 5 / 11$ & 533.60 & 301.94 \\
\hline $\mathrm{ECF}^{1 /}$ & $11 / 17 / 2008$ & 03/6/2009 & 9.20 & 1.31 \\
\hline $\mathrm{ECF}^{1 /}$ & $05 / 25 / 2005$ & $05 / 24 / 2008$ & 23.00 & 23.00 \\
\hline
\end{tabular}

${ }^{1 /}$ Formerly PRGF.

VI. Projected Payments to Fund ${ }^{2 /}$

(SDR Million; based on existing use of resources and present holdings of SDRs)

\begin{tabular}{lrrrrr} 
& \multicolumn{5}{c}{ Forthcoming } \\
\cline { 2 - 6 } & 2010 & 2011 & 2012 & 2013 & 2014 \\
Principal & 14.13 & 14.44 & 101.00 & 162.04 & 72.38 \\
Charges/interest & $\underline{3.24}$ & $\underline{4.32}$ & $\underline{4.09}$ & $\underline{2.28}$ & $\underline{0.52}$ \\
Total & 17.37 & 18.76 & 105.09 & 164.31 & 72.90
\end{tabular}

${ }^{2 /}$ When a member has overdue financial obligations outstanding for more than three months, the amount of such arrears will be shown in this section. 


\section{Safeguards Assessment}

Under the Fund's Safeguards Assessments policy, an update safeguards assessment of the Central Bank of Armenia (CBA) with respect to the PRGF approved on November 18, 2008, later replaced with the SBA approved on March 6, 2009 (and amended on June 22, 2009) was completed on May 4, 2009. The assessment found that the CBA's safeguards framework has been strengthened since the 2005 assessment in a number of areas, but some vulnerabilities remain. The CBA's governance structure remains to be modernized to allow for more independent oversight, and the CBA could further strengthen its internal audit function. A longer-term appointment of the external auditors would also improve audit efficiency and effectiveness. In case the authorities' interest in moving to a new program at the time of the next review materializes, an update safeguards assessment will be required.

\section{Exchange Rate Arrangement}

(a) The de jure arrangement is "free floating." The de facto arrangement was reclassified to "floating" from a "stabilized arrangement" effective March 3, 2009. The official exchange rate is quoted daily as a weighted average of the buying and selling rates in the foreign exchange market.

(b) Armenia maintains no exchange restrictions on the making of payments and transfers for current international transactions except for exchange restrictions maintained for security reasons, and notified to the Fund pursuant to Executive Board Decision No. 144-(52/51).

IX. Article IV Consultations

The 2008 Article IV consultation with Armenia was concluded on November 17, 2008. Armenia is subject to a 24-month consultation cycle.

\section{FSAP Participation and ROSCs}

A joint World Bank-International Monetary Fund mission assessed Armenia's financial sector as part of the Financial Sector Assessment Program (FSAP) update during February 16-March 4, 2005. The Financial Sector Stability Assessment (FSSA) report was discussed by the Executive Board on May 25, 2005.

\section{Resident Representatives}

Mr. Guillermo Tolosa, since January 2010.

\section{Technical Assistance}

The following table summarizes the Fund's technical assistance to Armenia since 2002. 
Armenia: Technical Assistance from the Fund, 2002-10

\begin{tabular}{|c|c|c|c|}
\hline Subject & Type of Mission & Timing & Counterpart \\
\hline \multicolumn{4}{|l|}{ Fiscal Affairs Department (FAD) } \\
\hline Tax policy and administration & Short-term & $\begin{array}{l}\text { September 17-October } \\
2,2003\end{array}$ & $\begin{array}{l}\text { MFE, State Tax Service } \\
\text { (STS), and Customs } \\
\text { Committee }\end{array}$ \\
\hline Tax policy & Short-term & April 22-May 6, 2004 & $\begin{array}{l}\text { MFE, STS, and Customs } \\
\text { Committee }\end{array}$ \\
\hline Tax administration & Short-term & July $13-27,2004$ & $\begin{array}{l}\text { MFE, STS, and Customs } \\
\text { Committee }\end{array}$ \\
\hline $\begin{array}{l}\text { Public expenditure management } \\
\text { advisor }\end{array}$ & & $\begin{array}{l}\text { November 7, 2003- } \\
\text { November 6, } 2004\end{array}$ & \\
\hline Tax administration & Short-term & October $5-18,2006$ & MFE, STS \\
\hline Public financial management reform & Short-term & $\begin{array}{l}\text { November } 27- \\
\text { December } 8,2006\end{array}$ & MFE \\
\hline Tax administration & Short-term & $\begin{array}{l}\text { October } 31 \text { - November } \\
13,2007\end{array}$ & MFE, STS \\
\hline Tax administration & Short-term & January $5-22,2008$ & MFE, STS \\
\hline Tax administration & Short-term & April 1-12, 2008 & MFE, STS \\
\hline Tax administration & Short-term & June 11-17, 2008 & MFE, STS \\
\hline Tax administration & Short-term & February 2-27, 2009 & MFE, STS \\
\hline Tax administration & Short-term & April 28 - May 22, 2009 & MFE, STS \\
\hline Tax administration & Short-term & $\begin{array}{l}\text { September } 23 \text { - October } \\
6,2009\end{array}$ & MoF, SRC \\
\hline Tax administration & Resident advisor & $\begin{array}{l}\text { March 1-September } \\
30,2010\end{array}$ & MoF, SRC \\
\hline Tax administration & Short-term & September 2010 & MoF, SRC \\
\hline \multicolumn{4}{|l|}{ Legal Department } \\
\hline Tax legislation & & $\begin{array}{l}\text { September 1, 2004- } \\
\text { December 31, } 2005\end{array}$ & \\
\hline Legislation Development \& FIU & Short-term & July 31-August 7, 2006 & \\
\hline Unified Tax Code & Short-term & June $16-23,2007$ & MFE \\
\hline Unified Tax Code & Short-term & April 13-18, 2008 & MoF, SRC \\
\hline \multicolumn{4}{|l|}{ Monetary and Capital Markets Department } \\
\hline Banking system issues & Short-term & April 15-19, 2002 & CBA \\
\hline $\begin{array}{l}\text { Banking system, deposit insurance, } \\
\text { foreign exchange market development, } \\
\text { and CBA monetary operations. }\end{array}$ & Short-term & June 24-July 4, 2002 & CBA \\
\hline
\end{tabular}


Unified financial supervision,

mortgage financing markets and

inflation targeting

Financial sector assessment program update

Recapitalization of the Central Bank of Short-term Armenia

Monetary policy and markets

Strengthening the implementation of monetary policy

Monetary policy implementation and money market development

AML/CFT preventive measures

Inflation Targeting, Foreign Exchange

Market Development and Responding

to Dedollarization

Exchange rate and collateral

Contingency planning, crisis

preparedness

Contingency planning, crisis

preparedness

\section{Statistics Department}

Data dissemination standards

Balance of payments: remittances

Multitopic bundled mission: national accounts, balance of payments, monetary and financial statistics

International Capital Market Department

Sovereign credit quality

Sovereign credit risk
Short-term

Short-term

Short-term

Short-term

Short-term

Short-term

Short-term

Short-term

Short-term

Short-term

Short-term

Short-term

Short-term
January 26-February 6 2004

February 16-

March 4, 2005

December 8-14, 2005

CBA

December 4, 2005-

December 31, 2006

March 8-21, 2006

CBA

October 5-17, 2006

CBA

April 1, 2006-April 30, 2007

August 29-September CBA 10, 2007

February 23-27, 2009 CBA

October 11-22, $2009 \quad$ CBA

March 29-April 15, CBA 2010

September 18-25, 2003 National Statistical Service

August 22-September CBA 5, 2006

January 25-February 5,2010

National Statistical Service, CBA

September 6-10, 2005 CBA

August 20, 2005- CBA

August 20, 2006 


\section{ANNEX II. ARMENIA: WORLD BANK AND IMF \\ COLLABORATION-JMAP IMPLEMENTATION}

\begin{tabular}{|c|c|c|c|}
\hline Title & Products & $\begin{array}{l}\text { Provisional timing of } \\
\text { missions }\end{array}$ & $\begin{array}{l}\text { Expected delivery } \\
\text { date (tentative) }\end{array}$ \\
\hline $\begin{array}{l}\text { 1. Bank work program } \\
\text { in next } 12 \text { months }\end{array}$ & $\begin{array}{l}\text { Economic policy report } \\
\text { DPO-2 } \\
\text { Programmatic fiscal work } \\
\text { Poverty monitoring and assessment } \\
\text { TA for DPO areas, including trade and } \\
\text { statistics } \\
\text { Public Debt Management }\end{array}$ & $\begin{array}{c}\text { Late } 2009 \\
\text { Quarterly } \\
\text { Late } 2009 \text { and early } 2010 \\
\text { Continuous } \\
\text { Ongoing } \\
\text { Ongoing }\end{array}$ & $\begin{array}{l}\text { January } 2010 \\
\text { Board discussion } \\
\text { expected mid-2010 } \\
\text { Draft report to } \\
\text { government in } \\
\text { mid-2010 } \\
\text { Mid-2010 } \\
\text { Ongoing } \\
\text { June } 2011\end{array}$ \\
\hline $\begin{array}{l}\text { 2. I M F work program in } \\
\text { next } 12 \text { months }\end{array}$ & $\begin{array}{l}\text { Third SBA Review } \\
\text { Fourth SBA Review } \\
\text { TA } \\
\text { - MCM (Contingency Planning, Crisis } \\
\text { Preparedness) Assessment Mission } \\
\text { - MCM (Contingency Planning, Crisis } \\
\text { Preparedness) Expert Follow Up } \\
\text { Mission } \\
\text { - MCM (Contingency Planning, Crisis } \\
\text { Preparedness) Expert Follow Up } \\
\text { Mission } \\
\text { - FAD (Tax administration-Various } \\
\text { operational issues to improve revenue } \\
\text { collection, resident advisor-four visits) }\end{array}$ & $\begin{array}{l}\text { February } 2010 \\
\text { May } 2010 \\
\text { October } 2009 \\
\text { April } 2010 \\
\text { July } 2010 \\
\text { March 2010- } \\
\text { September 2011 }\end{array}$ & $\begin{array}{l}\text { March } 2010 \\
\text { June } 2010 \\
\text { March } 2010 \\
\text { April } 2010 \\
\text { July } 2010 \\
\text { November } 2011\end{array}$ \\
\hline 3. Joint work program & $\begin{array}{l}\text { TA on banking sector assessment } \\
\text { Fiscal sustainability analysis inputs, } \\
\text { including debt sustainability analysis } \\
\text { JSAN for PRSP Update }\end{array}$ & $\begin{array}{l}\text { Late } 2009 \\
\text { Late } 2009 \\
\text { H1 } 2010\end{array}$ & $\begin{array}{l}\text { Mid-2010 } \\
\text { Mid-2010 } \\
\text { H2 } 2010\end{array}$ \\
\hline
\end{tabular}




\section{Annex III. Armenia: Relations With the European Bank for RECONSTRUCTION AND DEVELOPMENT (EBRD)}

(As of end-January 2010)

1. As of end January 2010 , the EBRD approved 77 projects in the power, transport, agribusiness, municipal and infrastructure, general industries, property, telecommunications and financial sectors. Total commitments amounted to around EUR 393 million.

2. There are three sovereign projects. First, the EBRD approved a sovereign guaranteed loan of EUR 54.8 million for construction of the Hrazdan Unit 5 thermal power plant in March 1993, partly aimed at the eventual closure of Armenia's nuclear plant in Medzamor. The government was contemplating the privatization of Hrazdan Unit 5 as the completion of this plant was constrained by limited budgetary resources. The EBRD had funded technical assistance for the Hrazdan privatization prospectus and followed the privatization process. The Hrazdan Thermal Power Complex was transferred to the Russian Federation in the context of the debt-for-equity deal. Second, in November 1994, the agreement on a EUR 21.8 million loan to build an air cargo terminal in Zvartnots airport was signed under a guarantee by the Armenian government. The airport was transferred to private management in 2002 (according to concession agreement). The new management has prepared a master plan for the development of the airport, which is expected to generate further cargo traffic for the cargo terminal. In April 2007, the EBRD approved a EUR 7 million loan to the State Committee for Water Systems, owner of the water and wastewater assets located in the small municipalities outside of Yerevan. The proceeds of this loan will be used to improve wastewater treatment in five municipalities located near Lake Sevan.

3. Most of the Bank's projects (97 percent) in Armenia are in the private sector. The Bank has committed EUR 85.2 million to Armenia in 2009 through 11 transactions, all in the private sector. In the end of December 2009, the Bank approved an additional loan to Zvartnots International Airport in the amount of EUR 29.6 million (to be supplemented by investments from $\mathrm{ADB}$ and $\mathrm{DEG}$ ). This project follows on from the successful completion, in May 2007, of the first phase of the Passenger Terminal, for which the Bank provided a EUR 14.8 million loan together with DEG (USD 10 million). This project involves the construction and purchase of equipment for the second phase of the Passenger Terminal complex at Zvartnots International Airport, Armenia and will facilitate the completion of Airport Terminal development reallocating all operations (arrivals and departures) from the old Airport building. The loan was a commercial facility with no sovereign support. Other private sector finance includes relatively smaller loans to private companies and equity participation in a number of companies in various sectors of the industry. In June 2009, EUR 4.2 million loan was signed with Elite Holding, for the construction of a modern residential building in Yerevan.

4. In 2009, EBRD approved a number of agribusiness projects. In November 2009, EBRD has approved a loan and equity contribution to Star Divide CSJC, the largest supermarket chain in Armenia operating 13 stores, in the amount of EUR 3.6 million. In the end of 2009, the Bank approved two loans to Saranist LLC (EUR 2.08 million) and Armglass LLC (EUR 2.1 million), two affiliated companies, leading producers of glass bottles and jars 
in Armenia. Also, there was a EUR 347,000 loan to Kotayk Brewery Limited Company, to finance its working capital needs.

5. In the banking sector, a first equity participation in the Commercial Bank of GreeceArmenia (EUR 1.1 million) was approved in late 1999. Now there are four local banks where EBRD participate in equity: Armeconombank, Byblos Bank Armenia, Ararat bank and Procredit Bank. The Bank also acquired an equity stake in an Armenian non-bank financial intermediary - Cascade Insurance and Reinsurance Company, an insurance subsidiary of Cascade Capital Holding.

6. The Armenia Multi-Bank Framework Facility II (AMBFF II), established to provide loans and equity to commercial banks and leasing companies in Armenia, was originally approved by the Board on 8 March 2006 for an amount of $\$ 40$ million, and then the facility was extended for $\$ 80$ million on 9 November 2007. In late 2009, the EBRD has approved a further $\$ 100$ million extension to AMBFF II (AMBFF II extension II) in order to support increased financial intermediation and the development of the financial sector in Armenia, to contribute to economic development by providing medium to long-term funding to selected Armenian financial intermediaries. The Facility will seek to develop new products for financial institutions, including provision of local currency loans.

7. The EBRD expanded its relationship with the partner banks in Armenia from four to twelve. Nine banks were provided with new credit facilities under the AMBFF. One institution (Armeconombank) was provided with a mortgage facility, and the first leasing facility in Armenia was signed with ACBA Leasing in 2008 for the amount of EUR 5.9 million. Co-financing facility with four local banks was also extended resulting in ten subloans to Armenian corporates. By means of co-financing lines the Bank has entered such new sectors as healthcare and telecom, in addition to significantly expanding its portfolio of agribusiness loans. A Trade Facilitation Program with the purpose to facilitate access of Armenian banks to trade financing was also made available to nine Armenian banks.

8. Supporting development of renewable energy was another core activity of the Bank. To that end, the EBRD joined forces with the WB, USAID, and Cascade Credit (a financing arm of Cafesdjian Foundation) to launch the Armenian Renewable Energy Programme (AREP). The Bank's participation took the form of a loan to Cascade Credit. The Bank also continued to finance renewable energy projects on its own through Direct Lending Facility, with two such projects signed. In addition to renewable energy, the Bank returned to the mainstream segment of the sector, seeking to support post-privatisation development of the sector with a loan to the Armenian privately owned power distribution company. In April 2009, the EBRD signed a EUR 42 million loan with Electric Networks of Armenia to upgrade and modernize the obsolete low-voltage infrastructure and improve energy efficiency.

9. The EBRD has launched the Turn Around Management (TAM) and Business Advisory Service programs in Armenia in 2003, originally funded by the EU-Tacis program but now funded from the ETC Fund, to support micro, small, and medium-sized enterprises. Since 2003 BAS has completed 623 projects in the amount of EUR 2.3 million, while TAM delivered 20 projects. 
10. Projects identified by the Bank for future development are well diversified across sectors, and include several relatively large transactions. Additional business opportunities are offered by the country's infrastructure sector, including projects in the public sector (mainly municipal). In this respect, the EBRD is exploring opportunities in public transportation, water, sanitation and solid waste treatment. The Bank is about to launch a USD 25 million program to finance projects for industrial energy efficiency and renewable energy through local banks.

11. The EBRD's current country strategy was approved in April 2009. The key priorities of the EBRD for the coming years are: (i) financial sector; (ii) enterprise sector, particularly SME and micro-enterprises financing through credit lines to Armenian banks or direct loans and equity investments, (iii) infrastructure investments in the development of alternative energy sources and municipal infrastructure projects; and (iv) policy dialogue with the government, other multilateral and bilateral donors and other stakeholders. 


\section{Annex IV. Armenia: Relations With the Asian Development Bank (ADB)}

(As of end-February 2010)

1. As of end-February 2010, ADB approved 5 projects in the transport, municipal infrastructure, and general budget support sectors. Total commitments amounted to about USD 224 million.

2. All approved projects are sovereign. The first project is Rural Roads Rehabilitation Sector Loan (USD 30.6 million) for rehabilitation of $220 \mathrm{~km}$ rural roads approved on November 15, 2007. The second one is Water Supply and Sanitation Sector Loan (USD 36 million) for repair and replacement of the exiting water supply infrastructure in small towns and neighbouring villages approved on December 18, 2007. The third project is Supplementary Loan (USD 17.3 million) to the existing Rural Roads Rehabilitation Project approved on November 18, 2008. The purpose was to finance the increase of the project cost resulting from construction materials price increase, domestic inflation, and appreciation of the Armenian dram. The fourth one is the Crisis Recovery Support Program Loan (USD 80 million) approved on July 15, 2009. This was a general budget support loan to protect social expenditures. And the last one is the first tranche (USD 60 million) loan under the North-South Road Corridor Investment Project approved on October 12, 2009. This loan is for rehabilitation of the $18.8 \mathrm{~km}$ of the four-lane Yerevan-Ashtarak highway. All approved loans are from the ADB concessional window under the Asian Development Fund (ADF). $\mathrm{ADB}$ has not yet provided loans to Armenia from its nonconcessional window under the Ordinary Capital Resources (OCR).

3. In addition to loan projects, the ADB is also involved in non-lending operations, mostly the Advisory Technical Assistance. Those are mostly research-oriented: Transport Sector Development Strategy for 2009-19 (transport sector road map for 10 years); Yerevan Sustainable Urban Transport Project (urban transport master plan for Yerevan city); Institutional Modernization to Improve the Business Environment (assisting the government with the introduction of online business registry system). Some of the advisory technical assistance might lead to loan projects, with the Yerevan Sustainable Urban Transport Project being one of the examples where the concept of the project resulted in an idea of the Yerevan city west by-pass road.

4. To increase the efficiency and long-term cooperation, the ADB offered a new instrument, namely funding of a project under the Multi Finance Facility (MFF). This facility allows approving a long-term sector assistance program to be disbursed in tranches. Under the MFF, the ADB has approved USD 500 million for the North-South Road Corridor Investment Project. The funds will be available for 7 years and country would request them in tranches, with the first 60 million tranche already approved. The Yerevan Sustainable Urban Transport project would be prepared as an MFF type with the indicative amount of up to USD 300 million.

5. The ADB's economic report and the interim operational strategy for 2006-09 for Armenia were approved in 2006. The Country Operational Business Plan for 2008-10 was approved in 2007. In 2010, the Bank is planning to prepare the Armenia Country Partnership 
Strategy for 5 years. The key priorities for the coming years are: (i) transport infrastructure; (ii) urban development; (iii) private sector, particularly banking, finances, renewable energy, and transport; and (iv) policy dialogue with the government, other multilateral and bilateral donors, and other stakeholders on country development prospective and reforms. 


\section{Annex V. Armenia: Statistical Issues}

1. Data provision has shortcomings, but is broadly adequate for surveillance. Further improvements in real, fiscal, and external sector statistics would be desirable in order to facilitate enhanced design and monitoring of economic policies. The overall quality, timeliness, and coverage of macroeconomic statistics have improved significantly over the past few years. The Fund has substantially facilitated this process through technical assistance from the Statistics Department, the Fiscal Affairs Department, and the Monetary and Capital Markets Department. On November 7, 2003 Armenia subscribed to the Special Data Dissemination Standard (SDDS). The April 2008 data ROSC mission prepared a detailed evaluation of the quality of the macroeconomic statistics. A multi-topic statistics mission visited Yerevan in February 2010 to review progress with implementation of past recommendations and follow up on the outstanding issues in national accounts, balance of payments, and monetary and financial statistics.

\section{Real sector statistics}

2. Despite the efforts to enhance national accounts statistics compilation, the quality of national accounts data requires substantial improvements. With respect to the statistical techniques used to compile gross domestic product (GDP), the two main problems are the coverage of informal activities and the derivation of volume measures. Basic data collection procedures have also partially improved, but substantial shortcomings remain in some areas, notably construction. The main issues arise from the monthly and quarterly business statistics surveys that still collect data on a cumulative rather than on a discrete basis. In construction, capturing informal activities needs to be improved and a new construction output price index, based on a sound methodology, needs to be developed to improve estimates of the construction output volume measures.

3. The national accounts statistics are compiled following the conceptual frameworks of the 1993 SNA and ESA 95. The classification of value added by economic activity follows the ESA 95 directions and data are published grouped accordingly to the A3, A6, A17 and A60 codes of the EU nomenclature of economic activities. The NSS is developing a plan for implementing the System of National Accounts 2008 (2008 SNA). Annual and quarterly GDP estimates are compiled at current prices, at comparable previous year's prices, and at average annual prices of the base year (1998) for the series up to the year 2006. Since 2007, GDP at constant prices is computed at average annual 2005 prices. Progress has been made in developing estimates of quarterly GDP at constant prices that are now published. The February 2008 ROSC mission found that compilation techniques for the estimates of GDP by production at constant prices were sound, however there was still need for improvements in the corresponding estimates of GDP by expenditure, particularly regarding the volume measures of imports and exports. The mission also found that government expenditures and some transactions with the rest of the world were recorded on a cash basis rather than the required accrual method. Moreover, quarterly data were still collected on a cumulative basis, which undermine their accuracy. 
Additionally, statistical techniques need improvements regarding the estimates of the imputed rental services for owner-occupied dwellings, and consumption of fixed assets.

4. The CPI covers 11 large population centers and the capital city. Since January 2006 the CPI has been computed using 2005 weights. Concepts and definitions used in the compilation of the CPI are broadly in line with international standards; source data and compilation techniques are generally adequate. The NSS compiles a ten-day and a monthly CPI. The ten-day index and the monthly index are disseminated jointly. The February 2009 ROSC mission recommended the development of an approach to include household expenditure on owner-occupied dwellings in the CPI calculations.

\section{Government finance statistics}

5. The budget execution reporting system compiles data on a cash basis supplemented with monthly reports on arrears and quarterly reports on receivables and payables. Daily revenue and cash expenditure data for the central government are available with a lag of one to two days. The Ministry of Finance $(\mathrm{MoF})$ is undertaking a comprehensive reform of the treasury system, including the introduction of an internal auditing system in line ministries and their budgetary institutions. A single treasury account (TSA) was introduced in 1996, and all bank accounts held by budgetary institutions were closed, except for Project Implementation Units that are required by donors to operate with commercial banks' accounts. Starting in 2002, some budgetary institutions have been converted into "noncommercial organizations" (NCOs). These units have been taken out of the treasury system and have their own bank accounts but report data on cash flows and balances to the MoF since 2003. The February 2009 ROSC report recommended including NCOs in the government finance statistics data published on national websites. These exceptions notwithstanding, all government receipts and payments are processed through the TSA, although there are still shortcomings on the timeliness and quality of data on the operations of local governments. Classification of government transactions by function and economic category are generally in line with the Manual on Government Finance Statistics 1986, and monthly data on central government operations are disseminated one month after the reporting period.

6. The budget presentation and the classification of items under the economic and functional classification of expenditures needs to be made more transparent; for instance, the data have been subject to frequent reclassifications, and wages for military personnel are reported in the broader category of "other" goods and services rather than as a wage item. The February 2009 ROSC report recommended using market value rather than face value for financial assets other than loans, and for non-financial assets. The reconciliation of central government with general government operations is done by the NSS in cooperation with the MoF.

7. Since 2008, government finance statistics meet the classification requirements of the Government Finance Statistics Manual 2001 ( G FSM 2001) for central government. The plans for improvement of the MoF envisage further significant progress within the next two years in 
implementing the GFSM 2001 classification for local government in 2009 and in accrual recording for all units of general government in 2010 .

Monetary and financial statistics

8. Monetary and financial statistics are provided on a timely basis. Daily data on the accounts of the Central Bank of Armenia (CBA) are provided daily with a one-day lag, while monthly data on the monetary survey are provided with three-week lag (and preliminary weekly data with a one-week lag). The balance sheets of the CBA and of the deposit money banks follow IAS methodology. Monthly interest rate data are provided with an one-week lag.

9. Responding to a STA request, the CBA has compiled and submitted a complete set of monetary data beginning from December 2001 using Standardized Report Forms (SRF). STA validated the resulting monetary aggregates and the data have been published since the December 2006 issue of IFS Supplement and are used to update IFS. An Integrated Monetary Database (IMD) has also been established by STA to share the SRF data with MCD.

\section{External sector statistics}

10. In 2009, the Armenian authorities decided to transfer the responsibility for compiling the balance of payments, international investment position (IIP), and external debt statistics from the NSS to the CBA. The NSS and CBA agreed on a target date for transferring the responsibility beginning with the data for the first quarter of 2011. The February 2010 mission agreed with the authorities on an action plan aimed to ensure a smooth inter-institutional transfer of the responsibility as well as the consistency and continuity in the production of the external sector statistics.

11. The coverage of external sector data has improved in recent years. Trade statistics are provided on a timely basis, and trade data by origin, destination, and commodity are generally available within a month. Price data for exports and imports are less readily available. Quarterly balance of payments statistics are generally available with a three-month lag. However, on remittances, which account for a significant part of the inflows, there are considerable discrepancies among available source data. Survey data are considerably lower than data obtained through the money transfer system. The NSS and CBA are working on establishing a compilation program that would enable proper measurement of remittances. The absence of a comprehensive, continuously updated business register hampers the coverage of transactions and institutional units; in particular, the coverage of the financial account items for the private nonbank sector.

12. Quarterly data on international investment position are published by the NSS within one quarter after the reference period, and the annual data within two quarters; and are also provided for publication in IFS. 
Armenia: Table of Common Indicators Required for Surveillance

(As of March 10, 2010)

\begin{tabular}{|c|c|c|c|c|c|}
\hline & $\begin{array}{l}\text { Date of latest } \\
\text { observation }\end{array}$ & Date received & $\begin{array}{l}\text { Frequency of } \\
\text { Data }^{7}\end{array}$ & $\begin{array}{l}\text { Frequency of } \\
\text { Reporting }^{7}\end{array}$ & $\begin{array}{l}\text { Frequency } \\
\text { of publication }^{7}\end{array}$ \\
\hline Exchange Rates & Mar 2010 & $3 / 10 / 2010$ & $\mathrm{D}$ & $\mathrm{D}$ & $\mathrm{D}$ \\
\hline $\begin{array}{l}\text { International Reserve Assets and Reserve Liabilities of the Monetary } \\
\text { Authorities }^{1}\end{array}$ & Feb 2010 & $2 / 26 / 2010$ & $\mathrm{D}$ & $\mathrm{D}$ & M \\
\hline Reserve/Base Money & Feb 2010 & $3 / 10 / 2010$ & $\mathrm{D}$ & $\mathrm{D}$ & $\mathrm{D}$ \\
\hline Broad Money & Jan 2010 & $2 / 25 / 2010$ & M & M & M \\
\hline Central Bank Balance Sheet & Jan 2010 & $2 / 5 / 2010$ & $\mathrm{D}$ & M & M \\
\hline Consolidated Balance Sheet of the Banking System & Jan 2010 & $2 / 25 / 2010$ & M & M & M \\
\hline Interest Rates ${ }^{2}$ & Feb 2010 & $2 / 25 / 2010$ & W & W & M \\
\hline Consumer Price Index & Feb 2010 & $3 / 1 / 2010$ & M & M & M \\
\hline $\begin{array}{l}\text { Revenue, Expenditure, Balance and Composition of Financing }{ }^{3}-\text { General } \\
\text { Government }{ }^{4}\end{array}$ & Q4 2009 & $1 / 29 / 2009$ & Q & Q & Q \\
\hline $\begin{array}{l}\text { Revenue, Expenditure, Balance and Composition of Financing }{ }^{3} \text { - Central } \\
\text { Government }\end{array}$ & Jan 2010 & $2 / 26 / 2010$ & M & M & Q \\
\hline Stocks of Central Government and Central Government-Guaranteed Debt ${ }^{5}$ & Jan 2010 & $2 / 26 / 2010$ & M & M & Q \\
\hline External Current Account Balance & Q3 2009 & $1 / 22 / 2010$ & Q & Q & Q \\
\hline Exports and Imports of Goods and Services & Jan 2010 & $3 / 2 / 2010$ & M & M & Q \\
\hline GDP/GNP & Q3 2009 & $1 / 29 / 2010$ & Q & Q & Q \\
\hline Gross External Debt & Q3 2009 & $1 / 22 / 2010$ & Q & Q & Q \\
\hline International Investment Position ${ }^{6}$ & Q3 2009 & $1 / 22 / 2010$ & Q & Q & Q \\
\hline
\end{tabular}

${ }^{1}$ Includes reserve assets pledged or otherwise encumbered as well as net derivative positions.

${ }^{2}$ Both market-based and officially determined, including discount rates, money market rates, rates on treasury bills, notes and bonds.

${ }^{3}$ Foreign, domestic bank, and domestic nonbank financing.

${ }^{4}$ The general government consists of the central government (budgetary funds, extra budgetary funds, and social security funds) and state and local governments.

${ }^{5}$ Including currency and maturity composition.

${ }^{6}$ Includes external gross financial asset and liability positions vis-à-vis nonresidents.

${ }^{7}$ Daily (D), Weekly (W), Monthly (M), Quarterly (Q), Annually (A); Irregular (I); and Not Available (NA). 
March 29, 2010

\section{IM F Completes Third Review Under Stand-By Arrangement for Armenia and Approves $\$ 73.6$ Million Disbursement}

The Executive Board of the International Monetary Fund (IMF) today completed the third review of Armenia's economic performance under a program supported by a Stand-By Arrangement (SBA). The decision enables the immediate release of an amount equivalent to SDR 48.485 million (about US\$73.6 million), bringing total disbursements so far an amount equivalent to SDR 350.425 million (about US\$532.2 million).

They Executive Board also approved a request for a waiver of nonobservance of the endDecember 2009 quantitative performance criterion on the net domestic assets of the Central Bank of Armenia (CBA).

The 28-month SBA was approved for an amount equivalent to a total of SDR 368.0 million (about US\$558.9 million) on March 6, 2009 (see Press Release No. 09/68), with a total amount of access augmented to an amount equivalent to SDR 533.6 million (about US\$810.4 million) on June 22, 2009 (see Press Release No. 09/228).

Following the Executive Board's discussion on Armenia, Mr. Murilo Portugal, Deputy Managing Director and Acting Chair, stated:

“Armenia's performance under its Stand-By Arrangement with the Fund has been strong, and the economic recession appears to have bottomed out, aided by supportive monetary and fiscal policies. The challenge remains to support the fragile recovery, address external vulnerabilities, and advance a credible fiscal consolidation plan over the medium term.

"Fiscal policy aims to continue to support the recovery, while gradually starting fiscal consolidation in 2010. Social spending will be protected. The authorities are committed to make good progress on the reforms in tax policy and administration, as well as on public expenditure and debt management. 
"Monetary policy aims to move from an accommodative to a more neutral stance, in order to head off potential inflation pressures. The authorities are committed to a flexible exchange rate regime, and aim to strengthen the monetary transmission mechanism to enhance the effectiveness of monetary instruments, as well as improve the central bank's communication strategy.

"The financial sector remains sound and well capitalized, and the authorities have strengthened their crisis preparedness and contingency planning frameworks. Further reforms will be important to ensure continued resilience to risks.

"The authorities are committed to pursue broad-based structural reforms to enhance productive capacity and promote long-term growth through an open trade regime, an improved business environment, better governance, and increased market competition in key sectors of the economy," Mr. Portugal said. 


\section{Statement by Yuriy Yakusha, Alternate Executive Director, and Grigor Sargsyan, Advisor for the Republic of Armenia March 29, 2010}

At the outset, on behalf of the Armenian authorities, we would like to thank staff for productive consultations held in Yerevan and management for their continued support and constructive engagement with Armenia.

The performance under the program remains strong. All performance criteria for endDecember were met, except for the target on net domestic assets of the Central Bank of Armenia (CBA). It was temporarily missed by a narrow margin on the last day of December, owing to the fact that the Central Bank tried to ease high liquidity pressures ahead of a 10day long holiday in January 2010.

Armenia is gradually recovering from a severe economic contraction of 14.4 percent in 2009 . The economy started showing signs of improvement after bottoming out late last year, and already in January posted small economic growth. Yet, there are many challenges ahead as fiscal deficit remains high, inflation pressures are elevated, and the remittance-fueled construction sector, one of the main drivers of the economic boom in the past few years, has yet to recover from a plunge of more than 40 percent last year. The GDP is projected to grow by about 2 percent in 2010, and the authorities believe that in the absence of negative external shocks they can reach an even higher growth.

In the medium term, in order to undergo a smoother and less challenging adjustment in the balance of payments, the authorities are considering a shift to the EFF/ECF blend.

\section{Fiscal Policy}

The authorities front-loaded a substantial fiscal stimulus to support economic activity, to protect the socially vulnerable and to overcome the negative consequences of diminished external demand and a sharp fall in remittances. Armenia has been successfully fighting poverty already for several years under the PRGF program, bringing it down to 23.5 percent before the crisis from 55 percent in 1999. The current Stand-By Arrangement helped the authorities mostly to avoid undoing previous efforts in this regard.

Although external public debt is projected to increase in coming years, it will remain at a level that will not expose the country to large debt sustainability concerns. The government is also constrained by the Law on Public Debt adopted in May 2008, which forces the government to plan the following year's budget so that the deficit does not exceed 3 percent of the average of the last three years' GDP, whenever the debt level reaches 50 percent of GDP.

Armenian authorities are committed to decreasing the fiscal deficit to 6 percent of GDP in 2010 from 7.5 percent last year. This will be achieved both by mobilizing higher revenues 
from an anticipated increase in economic activity and from improved tax collection, and by keeping expenditures at broadly the same level as in 2009 in nominal terms. Should revenues turn out to be higher than the level necessary to bring the budget deficit to 6 percent of GDP, the authorities intend to save the funds rather than increase spending. In the medium term, the authorities are committed to implement gradual fiscal consolidation on both revenue and expenditure sides, while making sure that an appropriate level of social and capital spending is in place. The authorities are committed to implementing the numerous measures in tax administration and other fiscal structural reforms that are at the core of the current program.

\section{Monetary Policy}

The CBA sees price stability as its main objective. Monetary policy is underpinned by the inflation-targeting framework. When inflation increased above the targeted band, the CBA reacted by gradually increasing the interest rates by 150 basis points since the beginning of the year. The authorities will continue gradual adjustment of the policy rate in response to unfolding price developments to ensure that the real interest rate stays in the positive territory, and inflation is contained within the target range.

At the same time, the authorities acknowledge weaknesses in the transmission mechanism due to increased dollarization. They are paying more attention to evolution of monetary aggregates as well as to enhancing the current framework of monetary policy. This includes a revision of the current rules of monetary policy implementation and of the CBA's communication strategy. To increase effectiveness of monetary policy, the authorities also plan to implement measures aimed at decreasing the dollarization rate and at deepening the secondary market for domestic interest rate instruments.

The authorities recognize that a flexible exchange rate serves the economy well, and will intervene in the foreign exchange market only to smooth out sharp movements. The foreign exchange market in Armenia still remains shallow and at times discrete: large demand causes exchange rate spikes in the market. The Central Bank agrees that interventions should not resist fundamental trends in exchange rate.

\section{Financial Sector}

Since the previous review in September of last year, the balance sheet of the banking system shows considerable improvement. The share of non-performing loans has been decreasing, while lending activity picked up somewhat, partly due to on-lending programs supported by the government. Recent stress tests show that financial system remains sound. Therefore, the authorities in line with the IMF advice, are planning a gradual phase out of the crisis-related supporting measures to the banking system, such as capital-matching subordinated debt and the guarantee on interbank lending.

Armenian authorities have also taken measures to mitigate vulnerabilities in the financial system. Specifically, several prudential and normative measures were introduced that would ensure that banks remain well capitalized, and banks' exposure to net open foreign exchange 
positions is limited. In particular, beginning in April 2010, the limit of $+/-7$ percent of capital on net open positions will come into effect. Another measure, an increase in risk weights in capital requirements for foreign currency loans, will come into effect in June 2010. 